UNIVERSIDADE DE SÃO PAULO

FACULDADE DE FILOSOFIA, LETRAS E CIÊNCIAS HUMANAS DEPARTAMENTO DE ANTROPOLOGIA

PROGRAMA DE PÓS-GRADUAÇÃO EM ANTROPOLOGIA SOCIAL

ADRIANA REZENDE FARIA TAETS

\title{
Por escrito: \\ o Carandiru para além do Carandiru
}

versão corrigida

São Paulo

2018 


\section{Por escrito: \\ o Carandiru para além do Carandiru}

Tese apresentada ao Programa de Pós-Graduação em Antropologia Social do Departamento de Antropologia da Faculdade de Filosofia, Letras e Ciências Humanas da Universidade de São Paulo, para a obtenção do título de

Doutora em Antropologia Social.

Orientadora: Profa. Dra. Fernanda Arêas Peixoto

De acordo, Profa. Fernanda Arêas Peixoto, 09/08/2018.

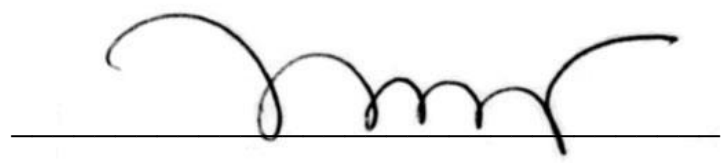

São Paulo 
Autorizo a reprodução e divulgação total ou parcial deste trabalho, por qualquer meio convencional ou eletrônico, para fins de estudo e pesquisa, desde que citada a fonte.

Faculdade de Filosofia, Letras e Ciências Humanas da Universidade de São Paulo

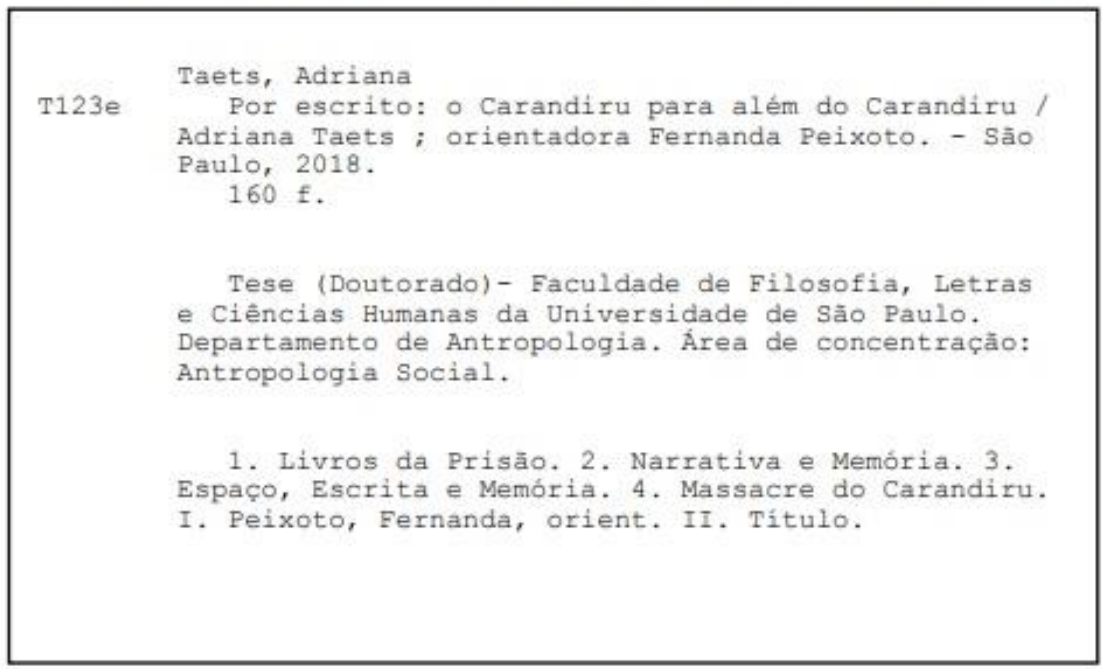


Aprovada em:

Banca examinadora:

Prof. ${ }^{a}$

Julgamento: Assinatura:

Prof. ${ }^{a}$

Julgamento: Assinatura:

Prof. ${ }^{a}$

Julgamento: Assinatura:

Prof. ${ }^{a}$

Julgamento: . Assinatura: 
À Maria Eduarda, flor dos meus dias.

Ao Francisco, riso de sorriso. 


\section{AGRADECIMENTOS}

À Fernanda Peixoto, a quem admiro pela força intelectual, olhar refinado, incansável trabalho de orientação e pela presença precisa nos momentos precisos. Ter recebido sua orientação durante o doutorado foi fundamental para a realização deste trabalho, mas também para compreender um pouco mais sobre isso que chamamos de Antropologia. Agradeço seu cuidado acadêmico e também pessoal. Agradeço por ser uma orientadora presente e exigente. Agradeço, ainda, pelo carinho e cuidado quando eles foram precisos.

Aos colegas do Coletivo ASA/Artes, Saberes e Antropologia: Alexandre Araújo Bispo, Aline Lopes Murillo, Bruno de Macedo Zorek, Bruno Ribeiro da Silva Pereira, Diogo Barbosa Maciel, Eduardo Alvarez Pedrosian, Isabela Oliveira Pereira da Silva, Júlia Ruiz di Giovanni, Júlia Vilaça Goyatá, Lorena Avelar de Muniagurria, Luisa Valentine, Luís Felipe Sobral, Rodrigo Martins Ramassote, Thais Chang Waldman, Thaís de Brito e Vinícius Spira, agradeço as discussões calorosas e sempre generosas, com vocês aprender Antropologia se tornou algo muito mais prazeroso.

Aos colegas que ingressaram comigo no doutorado, agradeço a companhia dos primeiros anos e a força compartilhada nos últimos momentos.

Aos professores Ana Cláudia Marques, Paula Monteiro, Carolina Junqueira, Robson Mendonça Pereira e Adriana Kanzepolsky, pela acolhida em suas disciplinas e pela possibilidade de diálogo que se abriu em cada aula. O vigor intelectual de cada um e a generosidade em receber alguém que se apresentava quase sempre como "de fora" me ajudou a construir caminhos para a análise e a compreensão das leituras que formaram a base para esta pesquisa.

À Ana Lúcia Pastore Shritzmeyer, Laura Moutinho, Natália Corazza Padovani e Carmen Fullin, agradeço pela prontidão em aceitar compor a banca de defesa e o carinho que expressaram ao fazê-lo. Essa acolhida calorosa me enche de alegria e coragem para prosseguir.

À Natália Corazza Padovani e à Laura Moutinho agradeço, ainda, a leitura cuidadosa e os comentários precisos na banca de qualificação. A generosidade com que lerat trabalho me ajudou a acreditar nele, dando continuidade. 
Agradeço, ainda, ao Christiano Tambascia, Júlia Ruiz, Silvana Nascimento, John Dawsey e Heloísa Buarque por aceitarem, tão prontamente, a compor a banca de suplentes. E assim dou início a um convite para um diálogo que espero realizar.

Agradeço ao Centro Universitário de Itajubá/FEPI, instituição que me acolheu durante a pesquisa do doutorado e onde exerço a docência há alguns anos. Agradeço, em especial, aos professores Maria Rosilene Coura, Rosana Mohallem, Ana Carolina Lopes, Marta Delfino, Luis Henrique Sales Oliveira e Ângela Morais, pelo companheirismo, pelo direcionamento profissional e pelo respeito ao meu trabalho.

Aos alunos do Centro Universitário de Itajubá agradeço pelo ambiente quase sempre acolhedor em sala de aula, agradeço a curiosidade, o cuidado e o respeito que nutriram por mim e agradeço, mais que tudo, a chance de aprender um pouco mais sobre antropologia e filosofia, nesse espaço em que, juntos, fomos aprendendo a elaborar perguntas.

À Carolina Junqueira agradeço o afeto e a delicadeza no trato de temas tão difíceis como a morte, sua coragem para falar sobre suas coisas me encheu de um novo ânimo para falar das minhas.

À Natália Corazza, colega-irmã, sempre, sempre presente, agradeço por me fazer sorrir sempre que, de longe, penso em você.

À Thais Waldman, companheira de jornada, agradeço o afeto, a voz tranquila e a leitura cuidadosa que me salvou em vários momentos dessa jornada, sua contribuição para este trabalho foi inestimável.

Ao André e a Marcinha, irmãos que ganhei justo nesse momento, a vocês agradeço a chegada, e agradeço por terem ficado, esperando que fiquem, e fiquem, e fiquem.

À Aline, minha amiga dos morros de Minas que, por vir de onde venho, entende o que vejo só com um olhar. Amiga de tão longa data, a você agradeço a amizade que ficou, apesar de tudo, junto a um amor que se fez ao longo de tantos anos.

Ao Décio e à Sirlene, pais de coração, agradeço pelo esforço cotidiano em ter a nora “doutora", fazendo de tudo para que os dias fossem mais fáceis, oferecendo alimento, cuidado e atenção com as crianças.

Aos meus pais, Silas e Suzana, gostaria de agradecer desde o começo. Agradeço o cuidado e o incentivo com a menina curiosa que eu demonstrava ser ainda pequena; agradeço o respeito sagrado pelos estudos e o esforço por me oferecer sempre o melhor; agradeço o apoio financeiro em tantos momentos e a promessa de "bancar meus estudos até o fim", 
mesmo quando esse fim parecia se renovar a cada ano e a jornada não acabava nunca; agradeço porque vocês sempre fizeram meus dias mais leves, me dando moradia, transporte, cuidado e afeto aos meus filhos, levando-os para passear enquanto eu precisava trabalhar e escrever tese. Sem vocês essa tese não seria possível. Sem vocês minha vida, assim como é, bonita, alegre, divertida e instigante, não seria possível. Obrigada.

À Maria Eduarda e Francisco, pessoas que chegaram ao mundo enquanto eu pesquisava sobre escritos da prisão. À primeira vista, talvez tudo tenha se tornado mais difícil: cuidar de duas crianças - sapecas como vocês são - e trabalhar e fazer doutorado podia parecer algo quase impossível. Mas não é verdade. Foram vocês que me puxaram para longe da solidão de uma pesquisa acadêmica, foram vocês que me permitiram ter finais de semana e descansar a mente enquanto me jogava na piscina ou andava de bicicleta. São vocês que oferecem um sentido para minha vida cotidiana, em que o trabalho, a pesquisa e as viagens constantes aparecem como um afazer fora de casa, mas não determinam quem eu sou. Eu sou Adriana, uma mulher que trabalha, viaja, ama, e é mãe de vocês. Obrigada, por cada sorriso, cada ligação nos momentos em que não estava em casa, por cada abraço apertado e pelas vezes que vocês bateram na porta enquanto eu trabalhava, "só para te dar um beijinho".

Ao Wagner, por todas as vezes que disse, incansavelmente, que tinha orgulho de mim. Agradeço sua compreensão, mesmo quando não havia o que explicasse a minha ausência e falta de paciência. Você caminhou comigo esse caminho difícil de uma pesquisa longa. Você ficou sozinho quando tantas e tantas vezes eu precisei ir para longe. Você acreditou em mim quando eu titubeava. Essa tese é sua também. Obrigada. 
Ler, tanto quanto escrever, é fazer a ressurreição de um mundo.

JoÃo ANZANELlo CARRASCOZA 
TAETS, Adriana Rezende Faria. Por escrito: o Carandiru para além do Carandiru. Tese de Doutorado. Programa de Pós-Graduação em Antropologia Social. Faculdade de Filosofia, Letras e Ciências Humanas. Universidade de São Paulo (USP). São Paulo. 2018.

\section{RESUMO}

O Massacre do Carandiru foi um evento crítico que dizimou mais de uma centena de presidiários na Casa de Detenção de São Paulo, em 2 de outubro de 1992. Ao expor a vida carcerária de forma dramática, o Massacre inaugura uma nova relação entre o dentro e o fora do cárcere, fazendo com que a sociedade extramuros volte a sua atenção para a vida prisional. Essa nova relação pode ser percebida e analisada a partir de um tipo de produção literária que ganhou espaço após a virada do século, momento em que alguns presos tiveram seus livros publicados, convertendo-se em autores e despertando um interesse do maior do público pelo universo prisional. Esta pesquisa toma como base para a compreensão sobre as novas relações que se estabelecem, a partir do evento trágico, entre o interior e o exterior da prisão, seis volumes publicados na década de 2000: Memórias de um Sobrevivente (2001), de Luiz Alberto Mendes, Vidas no Carandiru, Histórias Reais (2002), de Humberto Rodrigues, Sobrevivente André Du Rap (do Massacre do Carandiru) (2002), de André du Rap e Bruno Zeni, Pavilhão 9, Paixão e Morte no Carandiru (2001), de Hosmany Ramos, Letras de Liberdade (2000), vários autores, publicado pela Madras Editora e O Direito do Olhar: Publicar para Replicar (2009), publicado pelo Instituto de Defesa do Direito de Defesa. A análise de tais volumes permitiu lançar uma reflexão sobre as maneiras pelas quais os autores presos interpretam a prisão; a sua relação com o que se encontra fora das grades; as maneiras pelas quais constroem a memória. Permitiu, também, uma compreensão sobre a prática da escrita prisional, revelando as maneiras pelas quais as narrativas circulam - dentro e fora do cárcere - e como fazem circular afetos, memórias, pedidos de ajuda e ideias. Tais textos revelam, ainda, as disputas simbólicas voltadas para a prática da escrita no cárcere, nas quais sentidos pré-determinados sobre a prática são apropriados pelos presos e por eles reelaborados, oferecendo novos sentidos para a narrativa e para a própria experiência prisional. Essa literatura, portanto, evidencia um tipo de relação específica entre o dentro e o fora do cárcere, relação pautada na circulação de um tipo específico de texto, que movimenta sentidos e interpretações, tanto sobre a sociedade quanto sobre o próprio cárcere.

Palavras-chave: Livros da Prisão. Narrativa e Memória. Espaço, Escrita e Memória. Massacre do Carandiru. 
TAETS, Adriana Rezende Faria. In writing: The Carandiru beyond the Carandiru. Doctoral thesis. Postgraduate Program in Social Anthropology. Faculty of Philosophy, Letters and Human Sciences. University of São Paulo (USP). Sao Paulo. 2018.

\begin{abstract}
The Carandiru Massacre was a critical event that decimated more than a hundred prisoners at the São Paulo Detention House on October 2, 1992. The Massacre revealed a new relationship between the inside and outside of a prison by dramatically exposing prison life, making society outside the prison turn its attention to prison life. This new relationship can be perceived and analyzed from a type of literary production that gained space after the turn of the century, when some prisoners had their books published, becoming authors and arousing the interest of a large audience by the prison setting. In order to understand the new relationships established from the tragic event between the interior and exterior of the prison, the present study was based on six books published in the 2000s: Memórias de um Sobrevivente (2001), by Luiz Alberto Mendes, Vidas no Carandiru, Histórias Reais (2002), Humberto Rodrigues, Sobrevivente André Du Rap (do Massacre do Carandiru) (2002), André du Rap and Bruno Zeni, Pavilhão 9, Paixão e Morte no Carandiru (2001), by Hosmany Ramos, Letras de Liberdade (2000), several authors, published by Madras Editoria and O Direito do Olhar: Publicar para Replicar (2009), published by the Institute of Defense of the Right of Defense. The analysis of these books has given rise to a reflection on the way how the arrested authors interpret prison; its relation with what is outside the grids; and how they build memory. It also allowed a better understanding of the practice of prison writing, revealing the way narratives circulate - in and out of prison - and how they express affections, memories, requests for help, and ideas. These texts also reveal the symbolic disputes involved in the practice of prison writing, in which predetermined senses of practice are appropriated by the prisoners and reworked, offering new meanings for the narrative and the prison experience. Therefore, this type of literature reveals a specific type of relationship between the inside and outside of prison based on the circulation of a specific type of text, which enables senses and interpretations of society and the prison itself.
\end{abstract}

Keywords: Prison Books. Narrative and Memory. Space, Writing and Memory. The Carandiru Massacre. 


\section{ÍNDICE DE IMAGENS}

Figura 0.1 - Exposição 111, de Nuno Ramos, na Casa da Cultura Mário Quintana, Porto Alegre, RS, 1992 16

Figura 0.2 - Exposição SOBREVIVÊNCIAS/Uma exposição sobre vivências: Carandiru, Museu da Casa Brasileira, 2014 18

Figura 0.3 - Exposição SOBREVIVÊNCIAS/Uma exposição sobre vivências: Carandiru, Museu da Casa Brasileira, 2014 18

Figura 0.4 - O governador do Estado de São Paulo aciona o botão que detonou os 200 quilos de explosivos responsáveis pela implosão dos pavilhões 2 e 5 da antiga Casa de Detenção, 17/5/2005

Figura 1.1 - "Relembre em imagens o Massacre do Carandiru", Arquivo O Globo 51

Figura 1.2 - Capa e Contra Capa do livro Pavilhão 9, Paixão e Morte no Carandiru, de Hosmany Ramos, Geração Editorial, 2001 53

Figura 1.3 - Corpos de presos massacrados pela PM, na Casa de Detenção (Carandiru), foram autopciados no IML, 10/1/2014 57

Figura 1.4 - Cruzes instaladas pelos estudantes de direito da Universidade de São Paulo (USP), em frente ao prédio da faculdade, no centro da capital, para lembrar o número de presos mortos por policiais militares na Casa de Detenção do Carandiru, em 1992 60

Figura 3.1 - Autores Diversos, Letras da Liberdade, p.40-41 123

Figura 3.2 - Autores Diversos, Letras da Liberdade, p.62-63 125

Figura 3.3 - Autores Diversos, Letras da Liberdade, p.80-81 126

Figura 3.4 - IDDD, O Direito do Olhar, 2009, p.153 130

Figura 3.5 - IDDD, O Direito do Olhar, 2009, p.159 131 


\section{SUMÁRIO}

\section{INTRODUÇÃO}

NARRANDO O CARANDIRU: O MASSACRE E SUAS HISTÓRIAS .................. 15

A ESCRITA NO CÁRCERE: UM MAPA DE VIAGEM ............................................ 25

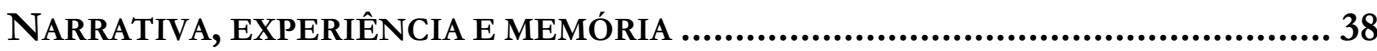

\section{CAPÍTULO 1}

MASSACRE, VIOLÊNCIAS, MEMÓRIAS: DOIS MODOS DE NARRAR ............ 50

1.1 UM MEMORIAL AOS MORTOS: O MASSACRE COMO UM MAPA PARA A MEMÓRIA

1.2 A NARRATIVA DO CÁRCERE: ESCRITA, COTIDIANO E VIOLÊNCIA NA

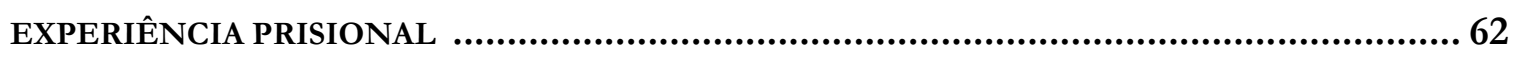

1.2.1 Construção de trajetórias e subjetividades ............................................................ 65

1.2.2 O cotidiano no cárcere: a solidariedade e a prática da escrita ............................... 67

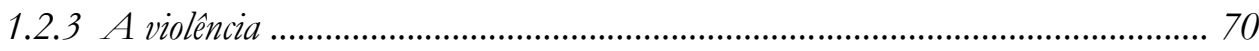

\section{CAPÍTULO 2}

A PRÁtica dA ESCRITA NO CÁRCERE E A PRODUÇÃo DE SUJEITOS

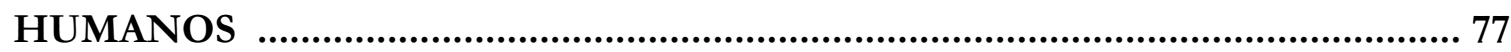

2.1 Luiz Alberto Mendes: A CONSTRuÇão do SUjeito Autor A PARTir DA

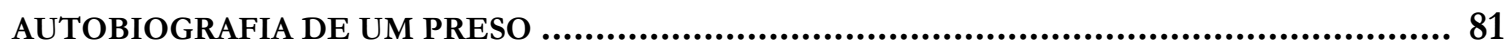

2.1.1 Prisão e violência: forma, conteúdo e princípio de entendimento.............................. 84

2.1.2 A circulação da escrita e a produção do sujeito-autor......................................... 92 
2.2 HUMBERTO RODRIGUES: UM PRESO-ESCRITOR 95

2.2.1 O contar dos dias: a elaboração de um diário 103

2.3 UM PROJETO FRUSTRADO E A CONSTRUÇÃO DE UM SUJEITO HUMANO 109

\section{CAPÍTULO 3}

CONCURSOS PRISIONAIS: RESSOCIALIZAÇÃO E RESISTÊNCIAS 112

3.1 LIVROS ESCRITOS A MUITAS MÃOS: MEDIAÇÃO E NEGOCIAÇÃO 114

3.1.1. Construindo o "sentido literal" 116

3.2 FALAR DE SI: INFÂNCIA, CRIMINALIDADE, ADEQUAÇÃO E RESISTÊNCIA ..... 132

3.3 O TEXTO COMO DENÚNCIA: NARRANDO AS INJUSTIÇAS DO SISTEMA JUDICIÁRIO BRASILEIRO 141

CONSIDERAÇÕES FINAIS 148

REFERÊNCIAS 151 


\section{INTRODUÇÃO}

\section{NARRANDO O CARANDIRU: O MASSACRE E SUAS HISTÓRIAS}

No dia 2 de outubro de 1992, após uma invasão do Batalhão de Choque da Polícia Militar de São Paulo no Pavilhão 9, um dos pavilhões da Casa de Detenção de São Paulo, no bairro do Carandiru, 111 presos foram mortos, segundo as informações oficiais. A invasão se deu com a intenção de conter uma rebelião causada por uma briga entre detentos. No dia seguinte, o evento ficou conhecido internacionalmente como o Massacre do Carandiru.

Assim que o Massacre ganhou nome, teve início uma proliferação de narrativas buscando narrar os eventos que culminaram na morte dos 111 presos: da Polícia Militar; do Governo do Estado de São Paulo; dos familiares; dos sobreviventes; das organizações não governamentais; da Pastoral Carcerária; do Judiciário. Tais narrativas tentavam compreender os fatos, organizar as informações, penalizar os culpados. Com o passar do tempo, outros relatos foram sendo produzidos, em âmbitos e esferas diversos. No Judiciário, provas foram coletadas, testemunhas ouvidas, um processo construído a fim de que os policiais militares envolvidos na ação fossem julgados por um Tribunal do Júri. Uma narrativa jurídica foi sendo tecida ao longo de mais de vinte anos, o que culminou na construção de um processo jurídico que ainda se encontra em aberto (MACHADO et alli, 2012). Enquanto isso, familiares das vítimas também construíam suas narrativas a fim de culpabilizar o Estado e receber indenizações pela morte de seus parentes.

Artistas e militantes também procuraram construir a memória do evento a partir de exposições, intervenções, instalações, performances etc. No final de 1992, pouco depois do

\footnotetext{
${ }^{1}$ No texto, passarei a me referir ao evento que marcou a morte dos 111 presos no Carandiru apenas como Massacre, como é, geralmente, referido nos textos e materiais que tratam do evento.
} 
Massacre, o artista Nuno Ramos realiza uma instalação na Casa de Cultura Mário Quintana, em Porto Alegre, com o título $111^{2}$. Nesta instalação, Ramos representa cada uma das vítimas do Massacre com paralelepípedos cobertos por asfalto e breu, cada um deles tendo recebido uma impressão em chumbo com o nome dos 111 presos assassinados, além de cópias de jornais que noticiaram o evento e cinzas de páginas da Bíblia queimadas. Um segundo ambiente trazia imagens de satélite do Cone Sul do Brasil, no dia e hora exatos da invasão da Casa de Detenção, em São Paulo. Os dois ambientes eram separados por um tule, em que havia a impressão de trechos do livro Cujo, que seria publicado pelo autor no ano seguinte.

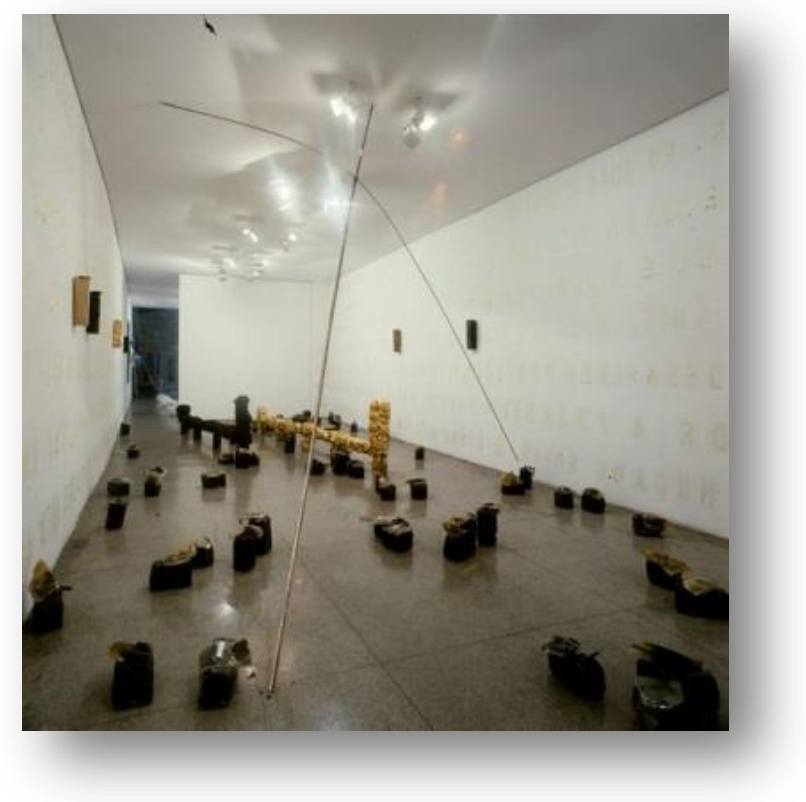

Figura 0.1: Foto da exposição 111, de Nuno Ramos, na Casa da Cultura Mário Quintana.

Fonte: Nuno Ramos, www.nunoramos.com.br

No dia em que o Massacre completou vinte anos, em 2 de outubro de 2012, o mesmo artista realizou uma ação na $30^{a}$ Bienal de São Paulo, intitulada 24 Horas 111. A ação consistiu na leitura ininterrupta, por vinte e quatro horas, dos nomes dos 111 presos assassinados naquele evento. A leitura foi realizada por vinte e quatro pessoas diferentes, que declamaram

\footnotetext{
2 A obra 111 foi primeiramente instalada em Porto Alegre, RS, e no mesmo ano foi exposta no Centro de Estudos Brasileiros, em Assunção, Paraguai, no ano seguinte, 1993, foi exposta no Gabinete de Arte Raquel Arnaud, em São Paulo, SP.
} 
a lista por uma hora. O pronunciamento foi ao ar pela Móbile Rádio BSP, a estação temporária de rádio-arte da Bienal.

Esta leitura ininterrupta foi retomada no dia 2 de novembro de 2016 e recebeu o título de Vigília 111, desta vez, artistas, intelectuais e ativistas, entre eles Zé Celso, Ferréz, Paulo Miklos, Bárbara Paz, Laerte, Marcelo Tas, Rita Cadillac, Marina Person, pronunciaram os 111 nomes dos presos assassinados no Massacre, durante vinte e quatro horas. A performance foi ao ar ao vivo por um canal no Facebook, , tendo recebido mais de um milhão de visualizações, segundo notícia veiculada pelo jornal Folha de S.Paulo, em 2 de novembro de $2016^{4}$. Esta nova leitura foi realizada como um ato de resistência devido à anulação, pelo Tribunal de Justiça de São Paulo, dos julgamentos pelo Tribunal do Júri, ocorridos em 2013 e 2014, que condenaram setenta e quatro PMs pela morte dos 111 presos. A anulação dos julgamentos ocorreu no dia 27 de setembro de 2016.

Em dezembro de 2014, o Museu da Casa Brasileira (SP) levou a público uma exposição intitulada Sobrevivências/Uma exposição sobre vivências: Carandiru. A exposição fez parte do projeto Casas do Brasil e procurou realizar um inventário sobre a diversidade de formas de morar no país. Após o final da exposição, foi lançado um catálogo. A mostra teve como principal objetivo revelar soluções encontradas pelos presidiários do Carandiru para sobreviverem frente aos obstáculos encontrados numa prisão como a Casa de Detenção, lidando com a precariedade, com a falta de liberdade e privacidade. Com curadoria da fotógrafa Maureen Bisilliat, a exposição contou com uma equipe de pesquisa liderada por Sophia Bisilliat e André Camarante, que visitou o Carandiru em outubro de 2001, tendo recebido a permissão para circular livremente pelos pavilhões. A mostra contou ainda com fotografias do Carandiru e também com a reprodução de algumas celas e artefatos produzidos na prisão.

\footnotetext{
3 Disponível em: https://www.facebook.com/111UmaVigilia/videos/402803166773987/. Acesso em 12/05/2018.

${ }^{4}$ Folha de S.Paulo, Ilustrada, 2/11/2016, "Com público de 1 milhão, acaba ato de Nuno Ramos por mortos do Carandiru", disponível em: http://www1.folha.uol.com.br/ilustrada/2016/11/1828761-com-publico-de-1-milhao-acaba-ato-de-nunoramos-por-mortos-do-carandiru.shtml. Acesso em 13 de fevereiro de 2017.
} 


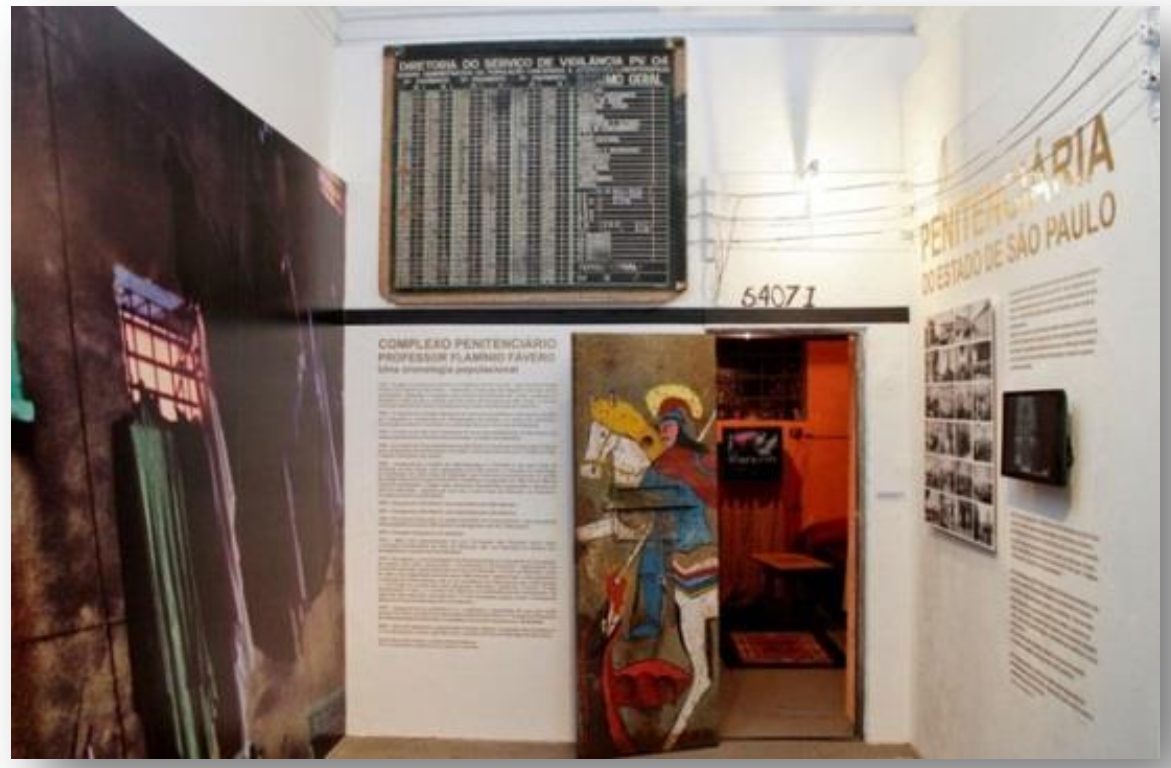

Figura 0.2: Imagens da exposição SOBREVIVÊNCIAS/Uma exposição sobre vivências: Carandiru, Museu da Casa Brasileira, 2014. Crédito fotográfico: Vinícius Stassola. Fonte: www.mcb.org.br

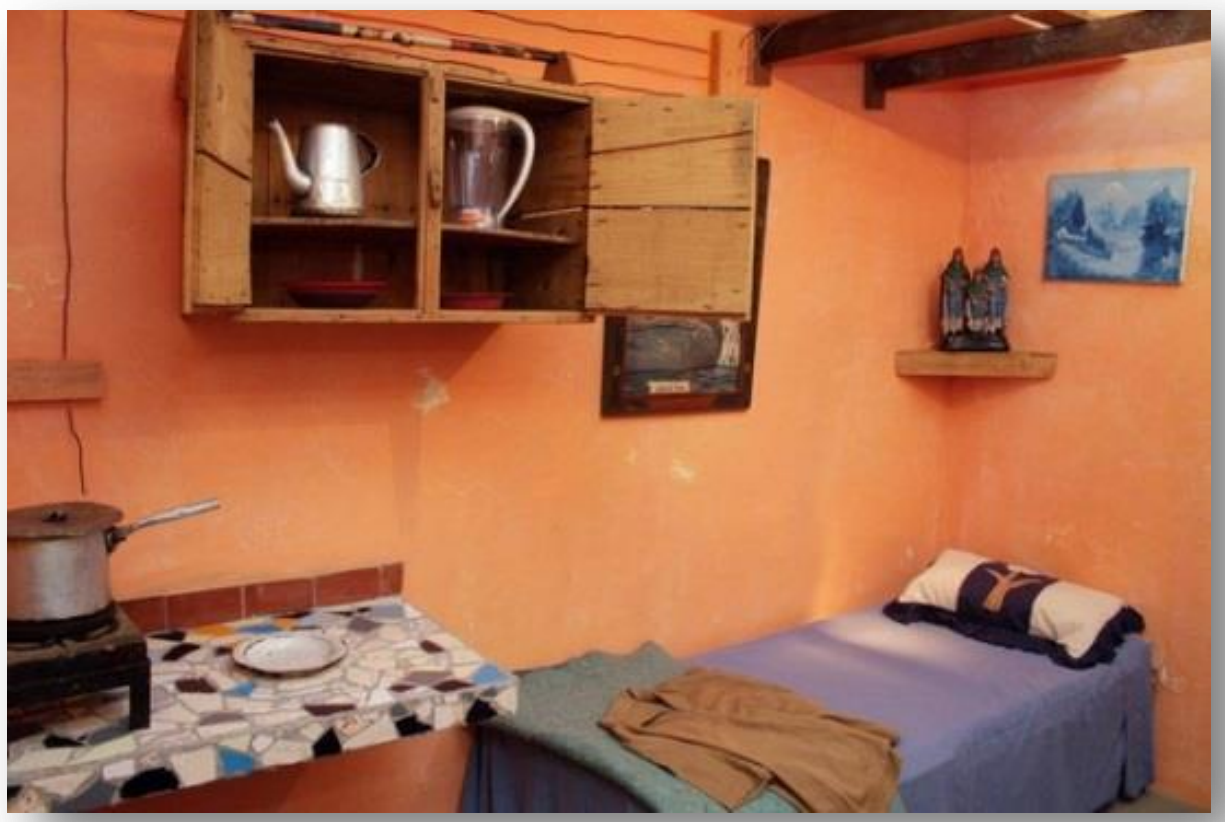

Figura 0.3: Imagens da exposição SOBREVIVÊNCIAS/Uma exposição sobre vivências: Carandiru, Museu da Casa Brasileira, 2014. Crédito fotográfico: Vinícius Stassola. Fonte: www.mcb.org.br 
Narrativas fílmicas foram também produzidas a partir do Massacre. Em 2003, o cineasta Paulo Sacramento distribuiu câmeras aos presos e os incentivou a mostrar, por meio de vídeos, o cotidiano da Casa de Detenção. O resultado foi o documentário Prisioneiro da Grade de Ferro (2004), que conta com mais de duas horas de duração e retrata o Carandiru a partir do ponto de vista de alguns internos, sendo possível conhecer celas, cultos religiosos, grupos de capoeira, faxina, cozinha, espaços e momentos dedicados ao futebol etc.

Anos depois, Sobreviventes, a história depois do Carandiru, documentário produzido no ano de 2015 por um grupo de estudantes de jornalismo da PUC de Campinas, relata a vida dos sobreviventes do Massacre depois que deixaram o Carandiru. O sentido de sobrevivente, aqui, pode ser compreendido como sobrevivente do Massacre e também sobrevivente do Carandiru, voltando-se para as maneiras como os egressos encontraram para reconstruir suas vidas após terem deixado a Casa de Detenção.

Ainda sobre a filmografia a respeito do Massacre do Carandiru, há também Carandiru, lançado em 2003, baseado na obra Estação Carandiru (1999), do médico e escritor Dráuzio Varella, e dirigido por Héctor Babenco ${ }^{5}$. O filme narra, uma vez mais, histórias cotidianas do Carandiru. O seu clímax é o Massacre, retratado a partir de cenas dramáticas, nas quais os presos são assassinados pelos Policiais Militares em suas celas, alguns deles pedindo, expressamente, para não morrer. Depois das tomadas que reconstroem o Massacre, alguns sobreviventes tomam a fala e voltando sua atenção para o evento, tentam compreender os motivos pelos quais não foram mortos naquele dia. Um desdobramento desse filme é o seriado Carandiru, outras histórias, produzido pela Rede Globo de televisão, constituído por dez episódios, exibidos entre junho e agosto de 2005. A série foi composta a partir do material não utilizado na produção voltada para o cinema. Os episódios foram gravados no Pavilhão 5, único a não ser demolido em 2002.

Tanto o filme quanto o seriado foram produzidos a partir de Estação Carandiru, de Dráuzio Varella. No livro, o narrador em primeira pessoa conta histórias dos presos que conheceu durante os dez anos que trabalhou como médico voluntário na Casa de Detenção, quando procurou criar um programa de prevenção à AIDS entre os internos. O livro, assim

\footnotetext{
5 Enquanto esteve na tela dos cinemas no país, o filme alcançou um público de mais de 4 milhões de expectadores, batendo o recorde de público daquele ano, segundo informações do jornal Folha de S.Paulo. Folha de S.Paulo, Panorâmica, Cinema, "Carandiru' é líder de público e renda no país", 6 de junho de 2003, http://www1.folha.uol.com.br/fsp/ilustrad/fq0606200339.htm. Acesso em 14/2/2017.
} 
como o filme, não é voltado para o Massacre, mas tem no evento o seu ápice ${ }^{6}$. Em 2012, Dráuzio Varella lança um novo volume sobre o Carandiru: Carcereiros. Neste segundo livro, o autor narra histórias dos homens que trabalhavam como agentes penitenciários na Casa de Detenção antes que ela fosse desativada. O foco agora são os funcionários, mas o contexto é o Carandiru, e o Massacre o evento que dá início ao livro. A diferença em relação ao primeiro é que este é narrado a partir do ponto de vista de um agente prisional que estava de plantão no Pavilhão 8, vizinho ao Pavilhão 9, local do Massacre. O livro é composto de pequenas histórias que tratam do cotidiano dos carcereiros, das estratégias que encontram para lidar com os presos e com a vida fora do presídio. O ponto de partida destas narrativas é sempre o Massacre.

Lembremos ainda que a Fundação Getúlio Vargas de São Paulo, a partir do seu Núcleo de Estudos sobre o Crime e a Pena, realizou, entre 2012 e 2015, uma pesquisa sobre o Massacre do Carandiru a partir de um enfoque jurídico. A pesquisa culminou na publicação do livro Carandiru não é coisa do passado (2015), organizado por Maíra Rocha Machado e Marta de Assis Machado. O volume, que conta com mais de 500 páginas, dedica-se à compreensão do funcionamento das instituições brasileiras à luz da instauração do Estado Democrático de Direito a partir da Constituição de 1988. O esforço dos pesquisadores é compreender como o Estado brasileiro se reconhece e se constrói a partir de um evento como o Massacre do Carandiru. Para além da edição do resultado da pesquisa, o Núcleo conta com a manutenção de uma plataforma colaborativa, em parceria com a Associação Nacional de Direitos Humanos, Pesquisa e Pós-Graduação (ANDHEP) chamada Memória Massacre Carandiru, Passado Presente de Violência Estatal em Instituições Prisionais ${ }^{8}$. A plataforma é um site onde os colaboradores publicam artigos, vídeos e outros materiais sobre o tema, o que funciona como um local de memória do Carandiru, além de um espaço para debate sobre a questão prisional no país. Neste site é possível encontrar uma grande quantidade de narrativas sobre o Massacre, desde documentários, até fotografias, depoimentos de sobreviventes, relatos institucionais e jurídicos, peças jurídicas etc.

Narrativas escritas, jurídicas, fílmicas, orais, literárias, artísticas: esta é apenas uma pequena lista que procura indicar a diversidade de relatos produzidos a partir do Massacre ao

\footnotetext{
${ }^{6} \mathrm{O}$ volume foi publicado em 1999, sendo que no ano seguinte, em 2000, ganhou o prêmio Jabuti de melhor livro do ano, categoria reportagem, e alcançou a marca de 500 mil exemplares vendidos.

7 Este livro também recebeu uma adaptação livre para a televisão, a série Carcereiros, tendo sido premiada na segunda edição do MIPDrama Screenings, uma das principais feiras do mercado de televisão do mundo, que acontece em Cannes, França. A série estreou em abril de 2018 na Rede Globo, tendo sido disponibilizada em canal pago no ano anterior.

${ }^{8}$ www.massacrecarandiru.org.br
} 
longo de vinte e cinco anos, revelando a presença continuada do evento no imaginário e na memória da sociedade brasileira desde então. O Massacre ocorrido em 2 de outubro de 1992 na Casa de Detenção assemelhou-se a uma explosão: em poucas horas, mais de uma centena de pessoas foi morta e outra centena ferida gravemente. Ainda que o evento tenha acontecido num espaço delimitado - dentro dos muros do presídio - seus efeitos foram sentidos a milhares de quilômetros de distância, abalando as estruturas políticas e jurídicas do país e afetando locais distantes da cidade. Não apenas espacialmente, mas também temporalmente foi possível sentir os ecos de tal evento traumático, que catalisou forças, continuando a produzir impactos em longo arco temporal. Após vinte e cinco anos, ainda vemos e sentimos a sua presença nos noticiários cotidianos, quando, por exemplo, se procura julgar (ou inocentar) os responsáveis pelos assassinatos ${ }^{9}$.

No início do ano de 2017, uma série de rebeliões em presídios do norte e nordeste do país levou à morte mais de 130 presos. Essas mortes, ao contrário do que aconteceu no Carandiru, foram decorrentes do confronto entre os próprios presos, o que ficou conhecido como "briga entre facções". Diferenças à parte, é o Massacre do Carandiru que baliza o entendimento e organiza os fatos, sendo indicado no noticiário como marco da história prisional no país: no dia 2 de janeiro de 2017, o jornal Folha de S.Paulo publica uma reportagem na seção Cotidiano com o seguinte título: "Maior matança em presídios desde o Carandiru deixa 56 vítimas no AM"; quatro dias depois, em 6 de janeiro de 2017, o mesmo jornal publica outra notícia, agora referindo-se à rebelião e às mortes ocorridas na Penitenciária Agrícola de Monte Cristo, em Boa Vista: "Confronto mata 31 presos em RR; essa é a segunda maior matança após o Carandiru”. O Massacre ocorrido no Carandiru, duas décadas antes, é sistematicamente acionado como um evento capaz de trazer entendimento à crise carcerária vivenciada pelas instituições no país, já que relembra não ter sido essa a primeira vez em que um número grande de pessoas morre, de forma dramática, em situação de encarceramento. O Carandiru torna-se, então, sinônimo de Massacre e deflagra, no imaginário social, a memória de um evento relacionado a mortes brutais, encarceramento e à própria vida na prisão, funcionando como um condensador simbólico.

A memória do Carandiru, e sobre o Carandiru, no entanto, vai sendo construída à contrapelo da história institucional. Em dezembro de 2002, o governador do estado de São Paulo, Geraldo Alckmin (PSDB), acionou os botões que implodiram dois dos cinco

\footnotetext{
9 O Globo, "Ministro do STJ suspende decisão que anulou o julgamento do Carandiru". 9/4/2018. Disponível em: https://oglobo.globo.com/brasil/ministro-do-sti-suspende-decisao-que-anulou-julgamento-do-carandiru22572276. Acesso em 12/05/2018.
} 
pavilhões que compunham a Casa de Detenção, mais conhecida como Presídio do Carandiru. Esta implosão fazia parte de uma política de desativação do presídio e da interiorização das prisões no estado. Os presos que se encontravam no Carandiru depois do Massacre foram aos poucos sendo transferidos para unidades prisionais no interior do estado. Em 2005, outros dois pavilhões foram demolidos também pelo governador Geraldo Alckmin, e o lugar deu espaço à construção do Parque da Juventude, que abriga uma grande área verde e instalações culturais e educacionais, como uma escola técnica, um museu de computação, uma biblioteca, entre outros equipamentos. Os relatos sobre as implosões contam que os prédios não gastaram mais de dez segundos para virem abaixo e virarem uma montanha de destroços.

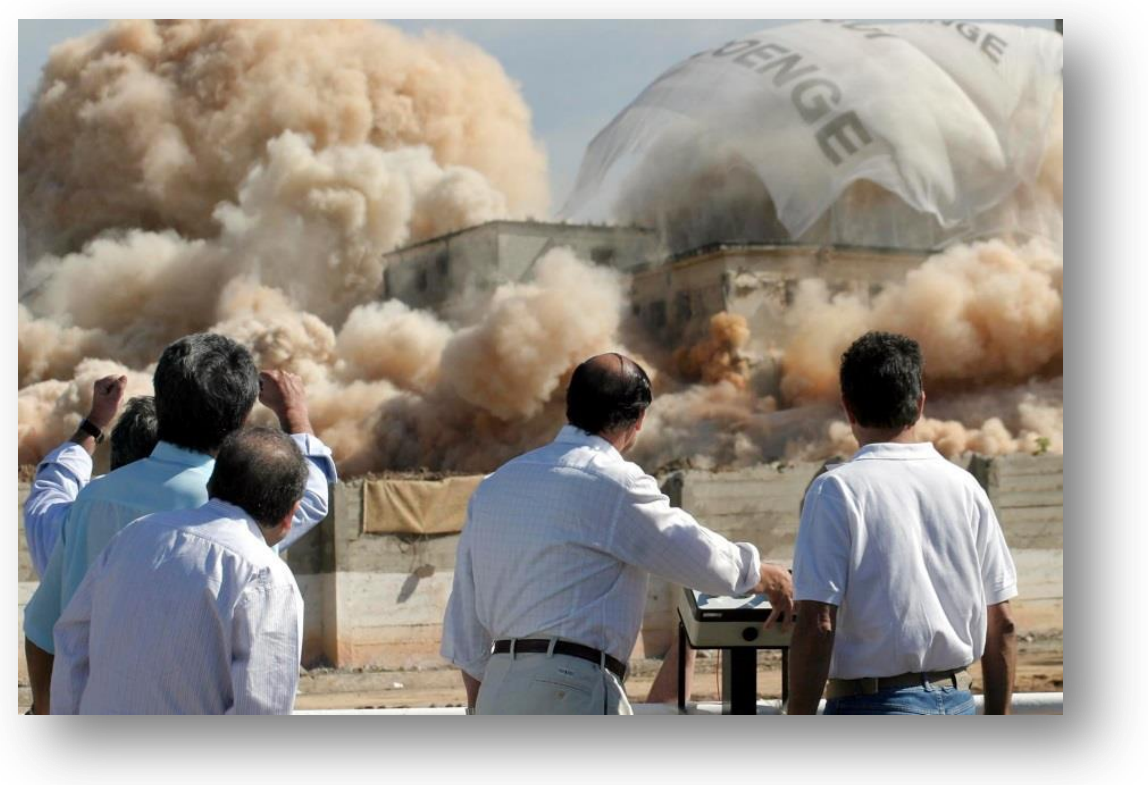

Figura 0.4: $\mathrm{O}$ governador do Estado de São Paulo aciona o botão que detonou os 200 quilos de explosivos responsáveis pela implosão dos pavilhões 2 e 5 da antiga Casa de Detenção. $17 / 5 / 2005$.

Fonte: Portal do Governo, www.saopaulo.sp.gov.br

A implosão dos edifícios dá origem a um novo espaço na cidade de São Paulo, que altera o seu entorno. Antes mesmo da primeira implosão, a especulação imobiliária já 
anunciava a valorização nos preços de aluguéis de imóveis na região ${ }^{10}$. No entanto, mais do que valorização urbana, a política de desativação da Casa de Detenção foi pensada com um processo de interiorização dos presídios paulistas ${ }^{11}$. A construção de novas unidades prisionais, abrigando um número menor de presos, foi concluída ao longo da década de 1990, aumentando o número de vagas prisionais no estado, ao mesmo tempo em que buscava apagar o "horror" da Casa de Detenção. Esse horror, frequentemente nomeado, no entanto, não se refere somente ao Massacre, mas também ao antigo estilo de aprisionamento: prisões enormes, pouco controle da administração sobre o cotidiano prisional e muita visibilidade do cárcere para fora dele. O Parque da Juventude nasce assim onde antes se encontrava a Casa de Detenção, ainda que tenham sido mantidas algumas unidades prisionais, como a Penitenciária Feminina da Capital e a Penitenciária de Santana, também voltada para a população feminina. O que antes era conhecido como Complexo do Carandiru abrigava não apenas a Casa de Detenção, mas também essas outras unidades prisionais. Apenas a Casa de Detenção foi demolida, o que significa que o Parque da Juventude faz divisa com alguns equipamentos penitenciários, que ajudam a guardar viva a memória da prisão e do evento dramático que aí teve lugar.

Durante minha pesquisa de mestrado (TAETS, 2012), em que entrevistei mulheres que trabalhavam como agentes penitenciárias, ouvi de algumas delas que jamais cruzavam o parque à noite, o que seria um caminho mais curto entre a Estação de Metrô Carandiru e a Penitenciária Feminina da Capital, e que preferiam dar a volta no quarteirão e andar quase vinte minutos a mais, já que o parque seria "mal assombrado". Uma resistência ao uso da área devido à sua ligação com o Massacre também foi notado pelos primeiros diretores deste equipamento. Em reportagem à Veja São Paulo, publicada no dia 17 de dezembro de 2010, o então diretor do parque, Paulo Pavam, afirmou que as pessoas evitavam visitar o parque devido à imagem negativa do presídio. Paradoxalmente, ele afirma ser exatamente a memória

\footnotetext{
10 Após o fim de todo o processo de desativação e implosão dos prédios, quando foi construído o Parque da Juventude, valorizou-se ainda mais aquela área da cidade . cf. "Fim da Detenção valoriza imóveis na região do Carandiru", Estadão, 4/10/2002, disponível em: http://brasil.estadao.com.br/noticias/geral,fim-da-detencaovaloriza-imoveis-na-regiao-do-carandiru,20021004p20219. Acesso em 17/2/2017.

11 Rafael Sabaini (2012), em etnografia realizada na cidade de Itirapina, SP, aponta para as modificações na paisagem urbana e nas relações sociais produzidas pela política de interiorização dos presídios paulistas. Tendo como base etnográfica esta mesma cidade, Giane Silvestre (2011) indica as maneiras pelas quais mulheres de presos transitam entre cidades interioranas paulistas e como constroem espaços simbólicos possíveis onde antes não havia espaços para questões relacionadas à vida prisional, tanto dentro quanto fora dos presídios.
} 
do presídio e a curiosidade que ele desperta o que atrai um público maior para o local em tempos mais recentes ${ }^{12}$.

O Carandiru se faz presente no lugar, assombrando-o, ainda que a política institucional do Estado tenha tentado empreender uma espécie de limpeza histórica; afinal, não seria de bom tom manter a memória de um evento traumático, nem fazer lembrar que São Paulo chegou a abrigar um presídio com uma população de oito mil pessoas. Mas, apesar desta política de apagamento, o Massacre do Carandiru permanece presente na memória, funcionando como produtor de narrativas, vinte e cinco anos depois.

Este breve relato indica como, durante duas décadas, relatos de naturezas distintas foram produzidos a partir do Massacre do Carandiru: livros, documentários, exposições, filmes, acervos históricos, pesquisas acadêmicas, relatórios jurídicos, documentos políticos. Cada um deles visa ora construir uma memória, ora inocentar ou culpar os responsáveis, ou ainda dar a conhecer ao grande público a história de uma população marginalizada, expressando revolta pela injustiça cometida naquele 2 de outubro. De uma forma ou de outra, é possível afirmar que o Massacre produziu, na sociedade, um interesse pelo cárcere. A partir de então, a prisão passou a ser notícia cotidiana, as pessoas buscando informações sobre o Carandiru, mesmo que não fossem diretamente relacionados ao Massacre. O Carandiru se tornava, assim, sinônimo de vida prisional: impresso no espaço (mesmo após a sua desaparição física), gravado na imaginação e alçando amplo voo no tempo. O evento passa, pouco a pouco, a nomear presídios em geral, e o Carandiru termina por indicar não apenas um local, mas uma tragédia, constituindo uma espécie de marca.

Rita Palmeira (2009) auxilia a compreender este processo de construção da memória do Carandiru ao analisar quatro volumes elaborados por presidiários no início da década de 2000. Ela indica ter havido um interesse crescente por essa produção específica que ela denomina "literatura marginal", literatura produzida a partir do cárcere e sobre o cárcere. O fenômeno assinalado pela pesquisadora para a década de 2000 pode ser observado, entre outros, a partir do recorde de público que o filme Carandiru alcançou, assim como pelas vendas do livro Estação Carandiru na mesma época. O que nos leva, mais uma vez, a afirmar que o Massacre fez com que a sociedade voltasse o seu olhar para o interior da prisão, o evento crítico funcionando para abrir os muros, conferindo visibilidade à vida prisional.

12 "Parque da Juventude convive com a memória do Carandiru", Veja São Paulo, Cidade, 17/12/2010, disponível em: http://vejasp.abril.com.br/cidades/santana-parque-da-juventude/. Acesso em 21/2/2017. 
Essa produção literária analisada por Palmeira lança luz sobre um tipo de construção da memória que parte da experiência no interior do cárcere e alcança a sociedade por meio da prática escrita. Dentre os diversos tipos de narrativas que vieram à tona a partir do Massacre, são os relatos dos presos o que mais nos aproximam tanto do evento em si, o Massacre, quanto da vida prisional, e serão eles, portanto, o objeto de interesse desta tese, que procura compreender as maneiras pelas quais o cárcere se constitui para fora dele por meio da escrita, tendo como ponto de partida o Massacre do Carandiru.

\section{A ESCRITA NO CÁRCERE: UM MAPA DE VIAGEM}

A escrita, por muito tempo, foi tomada como um divisor de águas entre sociedades, fundando, inclusive, uma divisão entre História e Pré-História, e colocando, de um lado, sociedades inteiras que não se reconheciam a partir da escrita e, de outro, aquelas que tinham nas letras a sua principal forma de reconhecimento. Essa divisão, no entanto, não foi compreendida apenas como uma forma de diferenciação, mas principalmente como um princípio de hierarquização, em que as sociedades que se reconheciam a partir da escrita foram tomadas como complexas e as demais avaliadas como "simples" ou "arcaicas" (GOODY, 2012). Goody chama atenção para o perigo dessa classificação, já que sua base compreende uma clara divisão entre o "nós" e "eles".

Sem querer entrar nos meandros da discussão lançada por Goody, tampouco nas reações críticas que ela conheceu, não parece difícil perceber que o ato de classificação que ele dizia ser marcador de assimetrias entre sociedades diferentes continua vigente e presente no interior das "sociedades com escrita". É possível percebê-la de forma nítida quando o objeto em análise é o cárcere, já que um dos seus sinais ou marcas é o baixo letramento da população carcerária em oposição a uma sociedade externa marcada pelo domínio da linguagem escrita.

No entanto, ao me aproximar de alguns escritos do cárcere que foram publicados em forma de livros, percebo que essa diferenciação é, ao menos, apressada, já que, como indica Goody, ela marca uma diferença, neste caso, entre um "nós" pesquisadores - pertencentes a um universo acadêmico que se constrói por meio da escrita - e um "eles", pobres, 
marginalizados, "suspeitos", com baixa escolaridade e, sobretudo, presos. Ao tomar como objeto de análise quatro livros escritos por presidiários, Memórias de um sobrevivente (2001), de Luiz Alberto Mendes; Pavilhão 9 - Paixão e Morte no Carandiru (2001), de Hosmany Ramos; Sobrevivente André Du Rap (2002), de André Du Rap e Bruno Zeni e Vidas no Carandiru (2002), de Humberto Rodrigues, assim como dois volumes que foram resultado de concursos literários em presídios femininos e masculinos, como Letras de Liberdade (2000), da Editora Madras e O Direito do Olhar: publicar para replicar (2009), do Instituto de Defesa do Direito de Defesa/IDDD, percebo que a escrita é própria ao cárcere, sendo uma prática familiar aos presos.

Em muitos dos estudos sobre o cárcere, a escrita é percebida como algo que aponta para a ressocialização (OLIVEIRA, 2008; PALMEIRA, 2009; BUCKERIDGE, 2011; SCAPINI, 2013): os presos, ao escreverem, se encontrariam num processo de "cura" ou "recuperação", ou ainda, a escrita seria percebida como um atestado de que o preso se encontra ressocializado, portanto, poderia voltar ao convívio com a sociedade extramuros ${ }^{13}$. Mas ainda que presente no cárcere, a escrita é percebida em geral como algo que lhe é estranho, apontando para a "outra" sociedade: a dos letrados. Se os presos escrevem, talvez o façam porque já se encontram transformados, não pertencendo mais ao universo prisional, encontrando-se prontos para o retorno ao convívio com a sociedade dos "homens livres" (PALMEIRA; 2009). Neste sentido, a escrita parece continuar funcionando como um marco divisório entre o nós e eles.

A escrita do cárcere não se limita a livros produzidos por presos e publicados por editoras interessadas nesse tipo de literatura - sobre o qual recai o interesse principal desta tese - mas diz respeito também a outros tipos de escrita, como cartas, poesia, letras de música, memórias, diários, produção de jornais, peças teatrais, tatuagens etc. Ao contrário do que parece apontar o senso comum - presos não escrevem - e diferente também do que alguns estudos sobre o cárcere sugerem - presos que escrevem estão em processo de ressocialização, o que os aproximaria de um universo exterior ou estranho à prisão - o cárcere faz transbordar a escrita, sendo um lugar profícuo para a produção e circulação de papéis e palavras.

Perceber o cárcere como um lugar de escrita não é algo novo, já que a história da literatura apresenta escritores renomados que produziram algumas de suas obras num

\footnotetext{
${ }^{13}$ Esta noção de ressocialização do preso por meio da escrita será alvo de análise na discussão que realizo sobre concursos literários nos presídios, trabalhada no terceiro capítulo desta tese.
} 
período de enclausuramento forçado, como foi o caso Dostoievski, em Recordação da Casa dos Mortos (1861), Oscar Wilde, em De Profundis (1897), de Graciliano Ramos, em Memórias do Cárcere (1953), Frei Beto, em Cartas da Prisão (1977), entre outros. A experiência prisional encontra-se assim intimamente associada à escrita. No entanto, esta prática não é exercida apenas por aqueles que já estão, de alguma forma, familiarizados com o universo literário, como o caso dos citados acima, mas também por presos comuns, incluindo aqueles que já eram familiarizados com as letras antes do aprisionamento e outros, que passaram a ler e a escrever na prisão.

Se a experiência prisional se liga à prática escriturária, cada tipo de escrita releva importantes aspectos da vida prisional. A leitura e análise de um conjunto de cartas produzidas por prisioneiros em diferentes penitenciárias do Paraná permitiu a Júlio Ponciano (2007) perceber um padrão de comportamento de busca de reconhecimento pelo outro por parte dos presos assim como a elaboração de estratégias de circulação de papéis que burlam a censura e controle dos agentes prisionais. Natália Padovani (2015), por sua vez, indica a maneira como as cartas trocadas por mulheres presas e seus maridos ou companheiras legitimam relações e fazem circular afetos. Heleusa Câmara (2001) demonstra como prisioneiros de Vitória da Conquista buscaram construir uma identidade que não estivesse atrelada ao cárcere por meio da escrita de suas memórias, produzidas a partir de oficinais de literatura realizadas na prisão. Maria Rita Palmeira (2009) toma alguns livros publicados por prisioneiros e a partir de uma análise de cunho literário aponta para uma tentativa de seus autores de construírem um pertencimento ao mundo editorial, afastando-se, assim, da vida prisional.

O interesse central desta tese volta-se para um tipo específico de escrita prisional: livros publicados por autores individuais ou coletivos que se encontravam presos ou tiveram como ponto de partida da escrita a experiência prisional. Diferente das cartas ou dos jornais, ou ainda de memórias escritas num contexto de oficinais literárias, os livros publicados permitem conhecer um tipo específico de circulação de papéis e palavras que transbordam o cárcere e alcançam o mercado editorial; permitem conhecer também um tipo particular de produção escrita, que tem sua origem numa relação singular entre o interior e o exterior do cárcere, tendo em vista que tanto os livros publicados a partir de concursos literários, de autoria coletiva, quanto os livros individuais, são publicados por editoras que não se encontram dentro dos presídios. 
Ao tomar alguns livros publicados no cárcere a partir da década de 2000 como objeto central da análise, é possível conhecer aspectos da experiência prisional que não seriam alcançados de outro modo, já que os livros deixam à mostra um tipo específico de relação entre o dentro e o fora do cárcere, seja por meio de sua publicação e circulação, seja pela relação entre os mediadores e os autores, que no caso dos volumes individuais são aqueles responsáveis pela “descoberta” dos escritores e pelo incentivo à publicação de sua obra e, no caso dos concursos, são os responsáveis pela realização do próprio concurso e posterior publicação do livro final.

Antes de iniciar a minha pesquisa de mestrado em Antropologia, que teve como tema a trajetória de mulheres que atuavam como agentes prisionais no estado de São Paulo, eu já havia travado contato com questões relativas à vivência prisional. Ainda na graduação, em 2005, enquanto atuava como estagiária no ILANUD (Instituto Latino Americano das Nações Unidas para Prevenção do Delito e Tratamento do Delinquente), participei de uma pesquisa interessada nos impactos que a nova lei de crimes hediondos tivera nas estatísticas criminais. Uma das etapas da pesquisa deu-se a partir de entrevistas estruturadas com presos e presas que estavam cumprindo pena devido a um crime tipificado como hediondo (ILANUD, 2006).

Ali se deu, portanto, meu primeiro contato com o cárcere, já que a fala daquelas pessoas e sua experiência na prisão me chamaram a atenção. Lembro-me de quando uma diretora de disciplina da Penitenciária Feminina da Capital, em São Paulo, levou nossa equipe para conhecer um dos pavilhões, era horário do banho e as mulheres transitavam entre as celas enroladas em toalhas. A diretora entrava em cada andar gritando para que as presas se vestissem, pois havia "visita". A visita éramos nós, a equipe de pesquisa do Ilanud, que não estava ali para visitar ninguém, mas para conhecer uma realidade em tudo estranha a nós. Nossa "invasão" naquele espaço, com direito de ir e vir num lugar marcado pela interdição de trânsito, marcou minha primeira experiência no cárcere.

No ano de 2009, o Fórum Brasileiro de Segurança Pública desenvolveu, em parceria com o Ministério da Justiça, a pesquisa Juventude e Prevenção à Violência, quando tive a 
oportunidade de coordenar uma das equipes de pesquisa. Nessa ocasião, entrevistamos cerca de 200 jovens e adolescentes que se encontravam presos ou cumprindo medidas sócio educativas em meio fechado. Foi quando pude conversar com diversos detentos e detentas, de diferentes estados do país, e ouvir deles suas histórias, sendo que, naquele momento e para aquela pesquisa, o que nos interessava era a trajetória na criminalidade de cada um desses jovens. Naquela ocasião pude conhecer unidades prisionais de cinco estados, de regiões diferentes do país. Porém, mais que conhecer as unidades prisionais, pude conversar com presos e presas de realidades diversas sobre suas trajetórias - na criminalidade e também naquilo que não envolve a vida no crime - e sobre o cotidiano no cárcere. Foi então que comecei a me interessar pelas narrativas por eles construídas para dar conta da experiência prisional.

No ano de 2010, ingressei no Programa de Pós-Graduação em Antropologia Social, no Departamento de Antropologia da USP, quando desenvolvi, sob a orientação da Profa. Ana Lúcia Pastore Schritzmeyer, uma pesquisa voltada especificamente para o cotidiano profissional de mulheres que trabalhavam como agentes prisionais (TAETS, 2012). Nesse momento interessava-me compreender a maneira como tais mulheres lidavam com o trânsito cotidiano entre o interior da prisão e o mundo fora dela. Ao entrar em contato com algumas mulheres agentes prisionais me deparei, no entanto, com algo diverso do que esperava a princípio: ao invés de me contarem histórias profissionais, muitas delas se voltavam para as histórias de presas, ou para relatos da prisão, e era por meio deles que teciam sua trajetória profissional de forma narrativa.

As narrativas destas mulheres ocuparam, portanto, o ponto central de minha dissertação de mestrado, e foi a partir delas que pude compreender que a convivência cotidiana entre guardas e presas faz com que ambas se assemelhem, tanto nos hábitos quanto nos pensamentos. Há, portanto, um esforço individual - e também institucional - da construção de diferenças entre guardas e presas, bastante próximas até mesmo em termos de extração social, quando no cotidiano o que as separa é cada uma ocupar um lugar diferente em relação às grades.

Para além dessa ideia central presente na dissertação, outros achados permearam minha pesquisa, indicando a presença maciça de histórias e de narrativas escritas e orais no cárcere. Uma de minhas interlocutoras afirmou que quando começou, ainda jovem, a trabalhar em uma penitenciária feminina, passou a atuar naquilo que é chamado de triagem, momento em que as presas que estão chegando ao presídio são avaliadas. Ali, ela era 
responsável por tomar conhecimento do crime cometido pela mulher em questão para assim encaminhá-la ao pavilhão mais adequado. Tempos depois, quando a guarda foi transferida para o trabalho dentro do pavilhão, ela conta que os crimes cometidos e presentes no prontuário de cada uma das presas perdiam seu sentido: no raio - lugar onde se encontravam as celas - o que importavam eram as histórias narradas pelas presas, e essas, segundo ela, eram muitas. Histórias de crime, de família, de amores, de dores, de solidão, de sonhos. Eram elas que preenchiam, segundo esta guarda entrevistada, todo o cotidiano prisional.

E essas histórias, algumas vezes, se materializavam em cartas, em pedidos de ajuda direcionados a advogados, ou ainda, em livros, como aconteceu com outra guarda que participou da minha pesquisa. Ao final de nossas conversas, ela me pediu que no próximo encontro eu levasse o computador, pois ela tinha um livro escrito e gostaria de me passar por pen drive. Nessa narrativa ainda não publicada, esta mulher conta histórias de sua família e da infância permeadas pela violência e pela presença do presídio no meio familiar, sendo que alguns irmãos, além dela, se tornaram agentes prisionais, e outro, preso.

A escrita no cárcere também se mostrava presente no cotidiano de algumas agentes, já que uma das funções que elas deveriam exercer era a censura das cartas escritas pelas presas e direcionadas para fora do presídio, assim como o controle daquilo que chegava de fora por meio das cartas. O controle dos escritos, a princípio, era justificado como necessidade de conhecer algum plano de fuga ou tomar conhecimento de algum falecimento na família das presas, e assim oferecer a elas atendimento social. Na prática, no entanto, o que acontecia por meio da censura era uma tentativa de controle da sexualidade das presas sexualidade muitas vezes exercida por meio de cartas.

As cartas trocadas entre sujeitos presos podem funcionar como uma maneira de garantir a manutenção do casamento. Padovani (2015) afirma que as trocas epistolares nos presídios garantem aos cônjuges um tipo de presença diferente da corporal; através delas, homens e mulheres, privados da presença física de seus cônjuges, se fazem presentes. As cartas eróticas muitas vezes são acionadas não apenas como expressão de afeto, mas também como comprovação, dentro do cárcere, da existência - e materialidade - de relações construídas fora daquele ambiente. E eram exatamente essas cartas as censuradas pelas agentes prisionais, que diziam, a partir de critérios próprios, o que era permitido e o que não era (TAETS, 2012). As cartas escritas pelas presas e para as presas circulam entre presídios e também fora do cárcere, sendo barradas, algumas vezes, pelo olhar "cuidadoso" de uma ou outra guarda. O trabalho de uma agente prisional, portanto, também é, em algum momento, 
exercido sobre os escritos que se produzem no cárcere, e sobre seus efeitos tanto no seu interior quanto fora dele.

Foi a partir dessas experiências que reafirmei ser o cárcere permeado pela palavra escrita, e de que esses diferentes textos circulam, fazendo circular sentidos, afetos, regras, obrigações e constroem relações - positivas ou negativas, de afeto ou de proibições. Preocupações que me levaram a delinear um novo objeto de pesquisa, com a ajuda de alguns títulos da bibliografia existente sobre o tema.

Muito tem sido dito sobre as produções textuais do cárcere ou sobre o cárcere, mas são alguns autores que me interessam de perto por elucidarem, em suas análises, os sentidos elaborados a partir da prática da escrita no cárcere. Heleusa Câmara publicou, no ano de 2001, o livro Além dos muros e das grades - Discursos prisionais, resultado de sua pesquisa de mestrado em Ciências Sociais, pela PUC de São Paulo. Neste livro, a autora analisa escritos de alguns detentos produzidos durante o projeto "O buraco da fechadura", oficinas literárias oferecidas aos presos no presídio de Vitória da Conquista, Bahia, e estes foram convidados a elaborar textos que dessem conta de suas experiências de vida. Alguns anos depois do início do projeto, a autora coleta esta produção escrita e faz dela o corpus de sua pesquisa. Do ponto de vista da análise, Câmara volta-se, principalmente, para a compreensão de como a escrita em um contexto de aprisionamento permite um maior controle sobre o tempo e sobre a culpa, atuando também na construção de identidades. Os textos analisados tratam de diversos assuntos; não são autobiografias, nem romances ou diários, antes, aquilo que Foucault (1992) chama de bypomnemata, caderno de notas em que se inscrevem anotações cotidianas sem ordenamento prévio em relação aos assuntos tratados. A autora percebe que há algumas recorrências nesses escritos: ou os presos versam sobre o período anterior à prisão, quando ainda não eram reconhecidos como presos ou, no sentido contrário, escrevem sobre o cotidiano prisional. Para ela, esses dois momentos definem um topos da escrita prisional: ao se voltarem para o passado, quando ainda não se encontravam presos, os autores procuram reconstruir uma identidade que nega o cárcere, reconhecendo-se como pessoas e não como presos; ao falar do cotidiano prisional, por sua vez, os autores reconhecem essa identidade de preso, mesmo que a considerem injusta ou injustificada, e passam a falar de sua rotina, de suas agruras, de formas de controlar o tempo e das atividades desenvolvidas diariamente no cárcere.

A produção textual no cárcere também foi objeto de análise de Júlio Ponciano (2007), mas seu interesse são as cartas produzidas pelos detentos. A partir de uma experiência 
drástica, quando foi acusado de corrupção de menores e levado para um presídio em Curitiba, Paraná, o autor, que já integrava um curso de pós-graduação em Antropologia Social na Universidade Federal do Paraná, percebeu o quanto as cartas produzidas e trocadas no presídio eram centrais no cotidiano do cárcere. Assim que deixou a prisão, inocentado das acusações, Ponciano voltou ao presídio para dar continuidade a sua pesquisa, que se focou, então, na produção e circulação de cartas, dentro e fora das grades. Ao analisar 200 cartas produzidas por detentos, o autor detectou alguns padrões e a partir deles identificou aquilo que chamou de "dialética da solidão". O preso, segundo Poncioni, encontra-se sozinho apesar da falta de privacidade: estando acompanhado por uma multidão, ele não se reconhece no outro e se sente só, já que retirado do convívio social, principalmente, da família. As cartas, portanto, funcionariam como uma ponte construída entre o preso e aquilo que ele deixou fora do cárcere, numa busca pelo outro.

A produção e a circulação de cartas elaboradas por presos e presas também foi objeto de atenção de Padovani (2015). Depois de realizar uma análise sobre o controle da sexualidade por meio de documentos produzidos burocraticamente na Penitenciária Feminina da Capital (PADOVANI, 2010), a autora dirige novamente sua atenção para o cárcere interessada em compreender a maneira como as redes de afeto, analisadas a partir de casos e casamentos na prisão, conectam a experiência prisional com o fora do presídio, revelando a maneira como casamentos são mantidos na prisão a partir da troca de cartas, que funcionam como a comprovação de uma união que se deu fora do cárcere, marcando também a presença física por meio do carinho, principalmente do erotismo presente nas cartas. Além da troca de afeto, as cartas atestam, para os devidos fins, as relações estabelecidas dentro do cárcere. Padovani analisa, por exemplo, alguns casos em que, na falta de documentos oficiais que comprovem o vínculo entre marido e mulher, estes lançam mão de escritos produzidos por si mesmos, com a assinatura de testemunhas, juntamente com a anexação de cartas trocadas entre os cônjuges, para atestar para as instâncias jurídicas a veracidade daquela união.

Os escritos institucionais elaborados no cárcere também receberam atenção de alguns pesquisadores, como foi o caso de Bruna Andrade (2011) que, num estudo antropológico, debruçou-se sobre documentos que versavam sobre a criação dos presídios femininos no Brasil, na década de 1930 e início da década de 1940 - como periódicos jurídicos e os Arquivos Penitenciários do Brasil - buscando encontrar neles a maneira como a mulher delinquente era compreendida na sociedade da época. A partir da definição de "mulher 
criminosa", mostra ela, criava-se uma concepção contrária: a mulher virtuosa. Os documentos analisados ofereceram os argumentos científicos da época para o enclausuramento desta mulher criminosa, dando o pontapé inicial para a criação dos presídios femininos no Brasil. Estes documentos, portanto, falam não apenas da prisão, mas também da sociedade exterior a ela, voltando-se para a maneira como a mulher devia ser e se portar em sociedade.

Um olhar atento a certa produção antropológica e sociológica sobre o cárcere revela, assim, a presença constante da escrita no espaço prisional, seja por meio da elaboração de cartas, de livros ou de notas, ou pelos prontuários, relatórios, fichas, processos - acervo que forma um conjunto de documentos oficiais e pessoais que circulam de diversos modos, elaborando sentidos diversos. O que nos afasta da afirmação de que o cárcere seria um lugar em que a escrita não se encontra presente. A palavra (oral e escrita) circula neste ambiente e o extrapola, gerando sentidos e estabelecendo estratégias para lidar com uma realidade marcada pela ausência de liberdade.

Para além dos documentos prisionais, das cartas e escritas de si, é possível identificar uma produção relativamente significativa no cárcere de textos que são posteriormente publicados, tornando-se livros, e que foram também objetos de exame, sobretudo do prisma da análise linguística e literária. O livro de Luís Alberto Mendes, Memórias de um Sobrevivente, um dos volumes que forma o corpus desta tese, foi a obra que recebeu mais atenção e interesse dos pesquisadores, tendo sido analisado a partir de vertentes diversas. Taufer (2011), interessando em verificar os processos de ficcionalização da memória presentes no livro de Mendes, elaborou uma comparação desta obra com Estação Carandiru, do escritor Dráuzio Varella, analisando cada uma delas a partir do par narrador-personagem e narradortestemunha. Ao se deter sobre as duas obras a partir de uma análise linguística, o autor buscou compreender as maneiras pelas quais a linguagem é utilizada para diferenciar, nas obras em questão, a ficção do testemunho.

Ainda na área da linguística, Scapini (2013) demonstrou, a partir da análise do livro de Mendes, a maneira como a tríade autor/narrador/personagem presente nas autobiografias a partir da identificação de um mesmo sujeito pode ser marcada por certa descontinuidade. A autora também analisa o texto de Mendes a partir do uso da linguagem e demonstra como esta permite identificar as descontinuidades entre narrador e personagem ao mesmo tempo em que possibilita a identificação entre personagem e autor. Sales (2009) é outra autora a se deter sobre o livro de Mendes no intuito de discutir os processos de aprendizagem da leitura. 
Sua análise focaliza a descrição realizada pelo autor sobre a maneira como se deu sua transformação em relação ao universo criminal a partir de aproximação com os livros. Segundo ela, foi a aprendizagem da leitura o que permitiu a transformação narrada pelo autor em sua trajetória, modificando seu status frente ao universo prisional, por um lado, e o universo letrado, por outro.

Diante dos estudos que se debruçam sobre Memórias de um sobrevivente, é possível perceber pelo menos dois interesses principais: de um lado, o espanto que causou o surgimento de um escritor que era, sobretudo, um presidiário. A partir desta inquietação inicial, os estudos que se seguiram pautaram-se na análise da maneira como tal autor construiu o seu estilo, apropriando-se dos códigos formais da escrita e como a apropriação de tais códigos o lançou simbolicamente para fora do cárcere. Estas pesquisas basearam-se, principalmente, em uma análise formal e estrutural do texto de Mendes.

Ainda no campo das Letras, Palmeira (2009) realiza uma análise que toma o livro de Mendes como objeto de interesse, mas o coloca ao lado de outras três obras: Sobrevivente André du Rap (2002), de André du Rap e Bruno Zeni, Vidas do Carandiru(2002), de Humberto Rodrigues e Diário de um Detento (2001), de Jocenir, o que permite um entendimento mais amplo sobre a produção literária no cárcere. A autora afirma que a prisão engendra uma forma específica aos textos produzidos ali e sua tese central é a de que a sociabilidade prisional define uma literatura que ela chama de híbrida, já que se pretende fiel a duas esferas contrárias e excludentes: as leis ou a moral do cárcere, e as leis ou moral daquilo que ela chamou de "mundo dos homens livres". Sua pesquisa, inserida na área dos estudos literários, procura compreender a estrutura formal de tais obras, analisando a construção do texto a partir do uso de certos vocábulos, do emprego de expressões orais ou formais, na interlocução construída ao longo do texto etc. O fio condutor da análise de Palmeira é a dupla adesão que ela percebe nos livros ao modus operandi da prisão, juntamente com o modus operandi do "mundo dos homens livres". Essa oposição entre os dois "mundos" guia sua análise, tendo em vista que a ambiguidade é constituinte nos livros em questão; ambiguidade que se releva na estrutura dos livros, como por exemplo, na presença de cartas, fotos, nomeação dos companheiros de cela, poesias de outros colegas, como sendo algo típico do "universo prisional".

Para Palmeira, a produção do livro revela um processo de ressocialização, já que indica o reconhecimento, por parte dos que escrevem, das regras que orientam o "mundo dos homens livres", ou ainda, dos "valores dos homens livres". Almejar o título de autor é, 
para Palmeira, uma indicação de que tais homens reconhecem esses valores e o almejam a partir de uma produção textual específica, qual seja, o livro. Nesse sentido, o livro, enquanto objeto, seria algo estranho ao universo prisional já que, para a autora, esse universo é marcado por um baixo letramento (PALMEIRA, 2009, p.37). Almejar algo estranho ao universo ao qual se faz parte seria, portanto, um sinal de reconhecimento tanto da própria condição, a de preso, quanto dos valores que orientam a sociedade extramuros, que reconheceria o livro como um valor não apenas a partir do seu consumo, mas principalmente a partir da sua produção: o autor é um sujeito reconhecido e valorizado nesse universo que não compartilharia dos valores do cárcere. Ao analisar cada uma das obras, Palmeira percebe essa dupla adesão, para além das características que marcam cada um dos volumes separadamente. Essa seria, então, a característica principal da escrita prisional.

A atenção de Palmeira para as maneiras pelas quais os autores do cárcere constroem um sujeito ambíguo, pertencente a dois mundos ou realidades opostas, desvendando as estratégias utilizadas por eles na construção deste sujeito, lança luz sobre a prática da escrita no cárcere, iluminando as relações tecidas aí para que os livros produzidos possam circular. A dupla adesão dos autores do cárcere a valores opostos, apontada pela autora, revela a maneira como a sociedade extramuros está presente no cárcere, determinando práticas e relações. Apesar dos livros produzidos alcançarem essa sociedade, Palmeira não expande sua análise para as relações que são construídas, a partir da publicação dos livros, com o fora da prisão. Sua análise focaliza os livros produzidos no cárcere, privilegiando a estrutura e a linguagem utilizadas.

Uma análise sobre a prática da escrita no cárcere não desvenda apenas os modos a partir dos quais presos representam suas experiências prisionais, a partir de certas estruturas linguísticas, mas revela, também, modos de perceber o cárcere e sua relação com a sociedade extramuros; formas e estratégias de se constituir enquanto sujeito em um lugar marcado pela anulação da subjetividade; tensões entre instituição prisional e presos nos modos diversos de perceber e compreender a experiência prisional, dentre outros. O cárcere, apesar de cercear a liberdade e o fazê-lo de forma violenta, ainda assim pode ser percebido como um espaço a partir do qual indivíduos constroem coisas: intepretações, objetos, relações, poderes, saberes etc.

É nesse sentido que me interessa uma dada bibliografia, que toma a prisão como objeto etnográfico e procura compreender aquilo que ela produz, analisando-a a partir da sua positividade. Que o cárcere cerceia a liberdade, imprimindo nos sujeitos uma violência 
institucional, o que por sua vez, multiplica os processos de violência, a literatura sociológica já o diz ${ }^{14}$. Interessa-me, no entanto, compreender a maneira como os sujeitos ali aprisionados constituem-se enquanto indivíduos, construindo relações, interpretando experiências e reconstruindo a sua realidade. É a partir deste olhar, interessado na prática dos sujeitos, que me aproximo, então, de alguns autores que buscaram compreender o cárcere a partir da experiência prisional e de seus efeitos.

Tendo como ponto de partida a cidade, num estudo de viés sociológico, Rafael Godói (2010) se vale do conceito de Foucault (1987) de "dispositivo carcerário" para buscar compreender as relações que são estabelecidas a partir do presídio, sendo que sua atenção voltou-se para bairros específicos na cidade de São Paulo e de Barcelona, na Espanha. Segundo o autor, o presídio é uma presença nestes bairros, que se faz sentir mesmo na vida daquelas pessoas que jamais foram presas, seja por meio de familiares, de vizinhos ou pela rede de apoio que se constrói para que um parente seja assistido na prisão. Este mesmo autor aponta para outros efeitos deste dispositivo carcerário: ao contrário do que comumente se diz - que a prisão destrói os laços familiares ou sociais - ele mostra a maneira como algumas famílias se ajudam mutuamente no momento da prisão de um de seus membros, sendo que estes laços, que são fortificados no momento da prisão, muitas vezes se desfazem quando o parente é liberto.

Em sentido semelhante, Giane Silvestre (2011), também a partir de um olhar sociológico, ao buscar compreender a dinâmica de uma cidade em torno de uma penitenciária, analisa os percursos de mulheres que se deslocam de suas cidades para Itirapina, uma pequena cidade no interior de São Paulo, que abriga duas unidades prisionais. A autora acompanhou diversas mulheres nos dias de visita, buscando compreender seus percursos e as redes de apoio construídas por elas para que seus maridos pudessem ser assistidos. Se, por um lado, a cidade evita o contato com tais mulheres, percebidas como “contaminadas" pela prisão, por outro, essas mulheres movimentam o mercado local a partir das compras em supermercados, padarias, pensões, hotéis etc. A rede de apoio construída pelas mulheres dos presos, que se ajudam mutuamente na elaboração das comidas que serão levadas aos presídios e também oferecem ajuda financeira uma à outra, só existe porque seus

\footnotetext{
${ }^{14}$ Há uma vasta literatura sociológica que trabalha a questão prisional, pensando principalmente os efeitos da prisão sobre os sujeitos aprisionados e sobre a sociedade. Os principais expoentes desta bibliografia são Gresham Sykes (1971), David Garland (2001) e Loïc Wacquant (2001), levando em conta uma literatura internacional; no âmbito brasileiro, temos Adorno (1991), Salla (1999), Barbosa (2005), entre outros.
} 
maridos se encontram presos. Os vínculos são fortalecidos a partir da prisão, já que a partir do momento em que os maridos são presos é necessário cuidar deles.

Outras etnografias ainda apontam para a positividade do cárcere, atentando para aquilo que ele produz, a partir de alguns dispositivos políticos. A organização política de um coletivo carcerário conhecido como Primeiro Comando da Capital foi o principal interesse de Karina Biondi (2009), que procurou analisar os conceitos de igualdade e fraternidade, presentes no lema do comando, e a maneira como eles se concretizam nas relações entre presos e também fora da prisão. Adalton Marques (2009), por sua vez, procurou compreender a maneira como um corpo de regras chamado de "proceder" organiza a realidade prisional por meio de disputas onde se procura construir uma "verdade". Para este autor, essa "verdade" é reconhecida por meio de uma espacialidade construída dentro da prisão: a separação entre o "convívio" e o "seguro". O que Marques demonstra é a maneira como o "proceder" e as disputas que ocorrem em torno dessa "verdade" extrapolam o cárcere, alterando vidas, experiências e até mesmo definindo a vida e a morte, dentro e fora do cárcere.

Estas etnografias, ao tomarem o cárcere como um objeto em relação - observando o que ele produz dentro de seus muros e também como se constitui como um sujeito social na relação com seu entorno - constroem algumas análises pautadas nesta positividade do cárcere, em que o que se valoriza em termos analíticos são as construções sociais e simbólicas que o cárcere engendra nas pessoas e a partir delas. É nesse sentido, então, que esta bibliografia me interessa de perto, já que me auxilia a analisar as práticas que se dão no cárcere e a partir dele, e o que tais práticas possibilitam. Se as análises acima elencadas na área da linguística e da literatura tomam os escritos do cárcere enquanto objetos textuais e os analisam a partir da sua estrutura formal, minha análise se diferencia destas, já que meu interesse está pautado naquilo que o texto produz, ou seja, o texto me interessa não apenas pelo seu conteúdo ou forma, mas principalmente por ser o produto de uma prática pautada num contexto específico, em que a prisão engendra formas de fazer. As etnografias elencadas, por sua vez, me auxiliam na compreensão destas práticas, já que elucidam alguns fazeres do cárcere: fazer político, como Marques (2009) e Biondi (2009), fazer casamento e família, como Padovani (2015), Lago (2014) e Bumachar (2016), fazer cidade, como Godói (2010; 2015), Silvestre (2011) e Sabaini (2012). Esses fazeres, no entanto, só podem ser pensados a partir da construção das relações entre o cárcere e o seu entorno, na circulação constante entre o dentro e o fora da prisão. 
Os escritos do cárcere que me proponho a analisar - livros autobiográficos, diários, contos e crônicas que foram publicados de forma individual e coletiva - também são produtos de uma experiência prisional. Apesar de seu conteúdo se referir à ausência de liberdade, à culpa, às torturas sofridas no cárcere, ao medo, à insegurança constante, é possível perceber na sua estrutura, na maneira como são construídos e como circulam, estratégias positivas para lidar com um cotidiano marcado pela privação. Presos e presas estão produzindo artefatos e elaborando estratégias para lidarem com suas experiências e os textos escritos são uma modalidade desta ação, revelando-se uma prática carregada de sentidos. A partir deles, presos e presas constroem relações, controlam o tempo, lidam com as ausências, se submetem a processos de construção ou reconstrução de identidade, manipulam tais processos, ganham e perdem a liberdade, falam de seus mundos e projetam outros. É esta escrita, ou melhor, esta prática o que me interessa analisar, tendo em vista a produção textual do cárcere: como se produz a escrita no cárcere e o que a escrita no cárcere produz será o fio condutor da análise realizada tendo como base os volumes selecionados.

\section{NARRATIVA, EXPERIÊNCIA E MEMÓRIA}

Tão logo o Massacre teve fim - quando os tiros cessaram, os cachorros policiais pararam de atacar e as baionetas deixaram de agredir os presos, quando os familiares dos detentos se aglomeravam do lado de fora dos muros do Carandiru em busca de notícias - os presos deram início ao trabalho de carregar os corpos já mortos de seus colegas, limpando os destroços e apagando muitos dos vestígios do horror que ocorreu ali. Relatos dos sobreviventes afirmam que os policiais obrigaram os presos a carregarem os cadáveres, já que temiam o contato com seu sangue e uma possível contaminação por HIV. Sangue, aliás, que escorria como um rio caindo pela escada que dava acesso aos andares do pavilhão, rio vermelho que foi lavado pelos próprios detentos, aqueles que sobreviveram ao Massacre e precisaram retornar ao local da tragédia para eliminar os vestígios da matança ${ }^{15}$. Findo o trabalho de limpeza, os sobreviventes foram encaminhados a hospitais próximos ao presídio,

\footnotetext{
${ }^{15}$ A artista Lygia Pape realiza uma instalação no Centro Municipal de Arte Hélio Oiticica, em 2001, intitulada Carandiru, na qual uma cachoeira de águas vermelhas faz uma alusão ao rio de sangue derramado no Pavilhão 9 , no dia do Massacre.
} 
receberam atendimento médico e aos poucos retornaram ao Carandiru, não para o Pavilhão 9, que restou inteiramente destruído, mas para aqueles pavilhões que não foram atingidos pela tragédia.

Veena Das (2007), ao trabalhar a noção de experiência a partir de eventos críticos, aponta ser o cotidiano o lugar privilegiado para uma compreensão da violência. $O$ evento crítico - o Massacre, no nosso caso, ou a Partição da Índia, no caso da análise da autora - é o momento do extraordinário, da violência extrema, em que a própria noção do humano é colocada em xeque. Diante de eventos como esses, o retorno ao cotidiano representa o momento em que a vida, com todas suas relações, pode ser reconstruída, reinventada e reinterpretada. Assim que, ao retornarem ao Carandiru, sendo alocados em outros pavilhões, os sobreviventes dão início ao um processo de reconstrução da experiência prisional, das relações com os familiares e das resistências em relação ao Estado; é nessa volta que constroem seu entendimento acerca da vida e da morte após Massacre.

A análise de Veena Das e o que ela chama de etnografia da violência inspiram de perto a compreensão do Massacre do Carandiru, como evento crítico. Ao se deter sobre as maneiras pelas quais homens e mulheres reconstruíram suas vidas e relações depois de dois eventos críticos - a Partição da Índia, em 1947 e $1948^{16}$; e os tumultos que tomaram lugar em Délhi depois do assassinato de Indira Gandhi, em $1984^{17}$ - Das se vê diante de narrativas que indicam a presença de graves violações aos homens e mulheres envolvidos, como raptos, estupros, tortura e assassinatos; narrativas do horror que a interessam em função dos modos diversos a partir das quais são construídas e, principalmente, em razão do que é reconstruído pelo trabalho de narrar ao longo do tempo. É na interseção entre a irrupção do evento crítico e a construção narrativa que a autora encontra a dimensão da experiência da violência e da reconstrução do cotidiano. É justamente por meio das composições narrativas que as pessoas envolvidas com a Partição de 1947 e 1948 e os tumultos de 1984 reconstroem a compreensão acerca do que é a vida, as relações, a família, a dignidade, a memória, o

\footnotetext{
16 O processo de independência da Índia em relação à Grã-Bretanha se deu entre os anos de 1947 e 1948 e culminou na criação de dois estados independentes: Índia e Paquistão. Esse processo, no entanto, não se deu de forma pacífica, já que os antigos colonos lutavam contra o domínio inglês ao mesmo tempo em que disputavam o poder a partir de grupos identitários muçulmanos e hindus.

${ }^{17}$ Indira Gandhi, primeira ministra indiana por quase vinte anos, foi assassinada por dois de seus seguranças, no jardim de sua residência, em outubro de 1984. Os assassinos eram parte do grupo étnico-religioso Sikh, que passou a ser perseguido depois do assassinato da primeira-ministra.
} 
casamento etc.; é por meio dos relatos que os sujeitos organizam a experiência da violência extrema, construindo um novo mundo possível ${ }^{18}$.

Seguindo as sugestões de Veena Das, é possível afirmar que as narrativas sobre o Massacre do Carandiru também são relatos de um mundo possível, e que a relação entre o evento que tomou o Pavilhão 9 no dia 2 de outubro de 1992 e as vidas daqueles que lá estavam naquele dia deve ser compreendida a partir da tentativa de reconstrução do cotidiano por parte daqueles que sobreviveram à invasão do Batalhão de Choque da Polícia Militar de São Paulo. Os sobreviventes carregaram os corpos dos companheiros mortos, lavaram os pavimentos, foi preciso testemunhar, realizar exames de corpo delito, produzir provas, assim como voltar a viver no presídio, reconhecer a ausência dos companheiros mortos, reconstruir a vida na prisão de antes. Em meio a tudo isso, não era possível falar sobre o Massacre. É quando o tempo realiza o seu trabalho, abrindo um espaço para a elaboração de narrativas, anos depois do evento, que a experiência dele pode ser elaborada.

As narrativas dos sobreviventes do Massacre formam uma miríade de textos diversa daquelas produzidas por sujeitos que não foram as vítimas do evento, indicada antes. Os relatos dos que viveram o evento estão pautadas na noção de experiência e no trabalho de reconstrução do cotidiano, sobre o qual fala Veena Das e que me interessa analisar. Mas, de novo: tais relatos não surgiram assim que o Batalhão de Choque deixou o Pavilhão 9; foi preciso que os anos passassem para que estes textos fossem elaborados, juntamente com a reconstrução das vidas dos sujeitos, das relações entre eles, da memória, do cotidiano.

Assim que, não por acaso, quase uma década depois, as narrativas dos sobreviventes começam a povoar o imaginário social sobre o Massacre, oferecendo uma nova perspectiva sobre aquele evento - a perspectiva da experiência. Experiência não apenas do horror, mas, principalmente, da reconstrução da vida após o evento violento. As narrativas dos presos funcionam, assim, como relatos do que foi vivido, mas também, e principalmente, como uma estratégia de sobrevivência, como aquilo que permite um retorno à vida depois do acontecimento extremo. É por meio da construção das narrativas - textos diversos e diferentes sobre o Massacre e sobre a prisão - que os presos reelaboram as relações e significações de seu mundo, marcado pela lembrança do Massacre, pela opressão contínua do Estado e pelo medo de que algo pior ocorra no momento seguinte.

\footnotetext{
${ }^{18}$ Das trabalha a noção de "mundo possível" ao identificar os limites preestabelecidos pela cultura punjabi. Os eventos críticos desestabilizam a noção de humano, no entanto, é o arcabouço cultural o que vai estabelecer os limites para a reconstrução do humano, determinando, portanto, o que é possível ou não. Para a autora, no entanto, o entendimento desse mundo possível se dá por meio do trabalho narrativo e do trabalho do tempo.
} 
São essas narrativas que ocupam o centro da minha atenção, pois elas permitem uma outra compreensão do Massacre e do cárcere. É essa dimensão de reconstrução do cotidiano após o evento violento que me interessa analisar, já que ela possibilita o desvendamento dos agenciamentos dos sujeitos submetidos à violência extrema e suas relações com o mundo possível que passaram a habitar.

Apesar do baixo grau de instrução ${ }^{19}$, presos e presas transitam pelo universo da escrita. Uma aproximação ao universo prisional revela o quanto tais sujeitos fazem uso desta prática para alcançarem objetivos diversos: cartas, bilhetes, letras de música, poesia e livros são produzidos cotidianamente, seja para estabelecer relações com outros presos e presas, para tecer relações com familiares e amigos fora do presídio, para produzir documentos que atestem relações perante o sistema de justiça, para narrar uma história, para se fazer conhecer, para participar de concursos, para tentar controlar o tempo, entre outras possibilidades (CÂMARA, 2001; PONCIONI, 2007; PALMEIRA, 2009; PADOVANI, 2015).

A prática da escrita pode ser percebida não apenas como uma recorrência, mas como algo próprio do cárcere; ela faz a prisão circular, transpondo, simbolicamente, as grades que a separam da sociedade extramuros. Se a prisão, num primeiro momento, foi considerada uma instituição total - para usar o célebre conceito de Goffman (2005) -, marcada pela baixa comunicabilidade entre o dentro e o fora, a prática da escrita, juntamente com outras práticas e dispositivos, construiu pontes na direção contrária: a prisão circula o tempo todo, transita, extrapola suas grades e muros, constrói comunicações, se faz conhecer pelos que estão impedidos de ali entrar, leva para fora os que não podem sair ${ }^{20}$.

Para além desses fluxos e elos que a escrita possibilita, as narrativas produzidas a partir da prisão também apontam para a construção da memória e do cotidiano após eventos

\footnotetext{
${ }^{19}$ Dados do último relatório do Depen sobre o perfil da população prisional, referente ao ano de 2014, aponta que $75 \%$ da população prisional brasileira possui até o Ensino Fundamental Completo e apenas 25\% possui um nível escolar superior a esse, contando com o Ensino Médio Incompleto até acima do Superior Completo. Ver Infopen, 2014.

20 As maneiras possíveis de circulação do cárcere podem ser percebidas como a questão de fundo que pauta diversas etnografias da prisão, como é possível perceber nos trabalhos de Godói (2010, 2015), Padovani (2015), Bumachar (2016), entre outros.
} 
violentos. Presos e presas escrevem para revisitar sua própria trajetória; para rememorar e compreender os ataques violentos da polícia; para contar os mortos; para projetar novos percursos; para esquecer e para lembrar. Alguns presos escreveram também para se reconhecerem e se constituírem como sujeitos após o Massacre, buscando resgatar uma dignidade de ser humano que foi anulada neste evento, e o fizeram, por vezes, a partir da construção da ideia de autor.

A produção de livros no cárcere e sua circulação, tanto dentro quanto fora do presídio, apontam para um tipo de prática bastante particular, distinta de outros vários tipos de escrita aí presentes. Lembremos que apesar dos textos serem elaborados no interior do cárcere, só se tornam artefatos materiais - livros - fora dele. Clara está, aponta Chartier (2007), a impossibilidade de separar no livro o que é textualidade e a materialidade, passível de ser reproduzida. Assim que se os originais dos livros do cárcere são produzidos na prisão, é preciso uma teia de relações tecidas nas inter-relações entre o dentro e o fora para que eles adquiram materialidade, por meio de exemplares publicados. Um livro do cárcere, portanto, jamais é produzido na solidão de uma cela, mas é antes formulado a partir de uma rede de laços e nexos que ligam o cárcere à sociedade envolvente, tanto no momento de sua realização, quanto por ocasião de sua publicação. Seguir o caminho de produção de um livro do cárcere é percorrer, assim, uma trilha repleta de jogos de convencimento, construção de sujeitos, mediadores legitimados, produtores de identidade, construção da verdade e produção da memória.

Os livros publicados no cárcere carregam, portanto, ao menos dois sentidos que me interessam discutir: são narrativas do horror, tendo em vista sua produção como resultado do Massacre do Carandiru, e são também produto de uma rede de relações produzidas na interrelação entre o cárcere e a sociedade externa à prisão. Por isso o corpus desta pesquisa foi constituído tendo em vista a publicação recente (a partir da década de 2000) de livros de autores presos (que escreveram a partir do Carandiru), portanto, foram produzidos nesse espaço simbólico entre o dentro e o fora do cárcere, permitindo uma compreensão e problematização deste espaço e das inter-relações construídas a partir dele; e também de um outro tipo de material, que chamo de literatura de concursos, que nada mais são que livros publicados a partir da seleção de textos de presos realizada a partir de um concurso literário. Este segundo grupo de materiais, por sua vez, lança luz para um outro tipo de relação entre o dentro e o fora, já que os concursos prisionais são elaborados num espaço exterior à prisão, mas tem como seu objeto algo produzido em seu interior. O desenho deste corpus de pesquisa 
me permitirá analisar as disputas simbólicas constituídas entre os atores que têm sua origem no cárcere (presos, instituição prisional e sistema de justiça penal, principalmente), elaboradas a partir da prática da escrita e que definem interpretações do mundo, do sujeito preso e, principalmente, da própria prisão.

Memórias de um Sobrevivente, de Luiz Alberto Mendes (1952-), foi publicado pela Companhia das Letras ${ }^{21}$ em 2001. O livro é uma autobiografia ${ }^{22}$, narrando a história de vida do autor, desde a infância até o momento em que edita o volume, quando ainda se encontrava preso no Carandiru. Mendes retoma sua trajetória, da infância, passando pela adolescência, suas primeiras experiências com roubo, o uso de drogas, as diversas passagens pela carceragem da polícia e do RPM (Recolhimento Provisório de Menores), para então narrar sua vida como assaltante: as enormes quantias de dinheiro adquiridas por meio de assaltos, as armas, as drogas, além das relações amorosas e sexuais. Finalmente a narrativa se detém nos primeiros dez anos de uma pena que durou três décadas, momento inicial quando o autor aprende a sobreviver no cárcere, contando os dias e se aproximando dos livros a partir de um esforço autodidata.

Antes de se tornar um escritor dentro do cárcere, Mendes aproxima-se do universo da literatura por meio da aprendizagem da leitura. Fora do presídio, ele não possuía nenhuma familiaridade com os livros; é aí que ele conhece um companheiro de cela que o apresenta ao universo da leitura. A introdução nesse novo mundo leva-o a escrever suas memórias e produzir uma autobiografia, publicada enquanto ele ainda se encontrava preso. O livro interessa para esta análise na medida em que narra a transformação de sua vida a partir da leitura e da escrita. O controle desses novos instrumentos e os resultados que eles produzem permitem que o autor se diferencie dos demais companheiros de prisão e alcance o status de escritor $^{23}$. O livro em questão lança luz sobre a relação entre prisão e escrita a partir do aprendizado e da prática da leitura e da escrita em um espaço de reclusão.

Vidas no Carandiru, Histórias Reais, foi escrito por Humberto Rodrigues (1933-) e publicado pela Geração Editorial ${ }^{24}$ no ano de 2002. Rodrigues tinha 67 anos quando foi

\footnotetext{
${ }^{21}$ A editora Companhia das Letras publica, ainda, dois livros do autor: Às cegas (2005) e Confissões de um homem livre (2015), tendo reeditado Memórias de um Sobrevivente como edição de bolso em 2009.

22 Tomo aqui o termo autobiografia na acepção de Lejeune (2008): um texto que versa sobre uma trajetória de vida em que há princípio de identidade de nome entre o autor do texto, narrador e a pessoa de quem se fala.

${ }^{23}$ Depois de Memórias de um Sobrevivente, Mendes publicou mais quatro livros: Tesão e prazer, memórias eróticas de um prisioneiro (2004); Às cegas (2005); Cela Forte (2012); Desconforto (2013) e Confissões de um homem livre (2015), sendo que alguns deles tomam o cárcere como tema.

${ }^{24}$ A Geração Editorial foi fundada em 1992 pelo jornalista Luiz Fernando Emediato e se tornou conhecida por publicar livros considerados polêmicos pelo teor de denúncia que traziam sobre assuntos políticos. Em 1992,
} 
preso; antes disso, havia tido uma carreira de sucesso como jornalista, trabalhando como diretor e gerente em veículos importantes da imprensa brasileira, como a Editora Abril e a Manchete. Essas informações, trazidas já no início do texto, fornecem uma chave para o livro: Rodrigues é um homem familiarizado com as palavras escritas e os textos, o que o auxilia na elaboração da obra. Entretanto, não conhece a experiência prisional nem seus códigos de ética ou conduta, já que nunca havia sido preso; tampouco experimentara situações semelhantes ou convivido com pessoas em situação de vulnerabilidade e criminalidade.

O livro de Rodrigues é formado por duas partes distintas: a primeira baseia-se em um diário elaborado pelo autor enquanto esteve preso (entre julho de 2000 e outubro de 2001) e a segunda é formada por contos construídos a partir da história de vida de alguns de seus companheiros de prisão. No diário, o autor relata o seu dia-a-dia no cárcere, as experiências vividas, o cotidiano prisional, a estrutura do presídio e as relações que se dão no seu interior, discutindo, principalmente, a elaboração do que ele chama de "meu livro", que é, na verdade, a segunda parte do volume, onde se encontram as histórias de seus companheiros. Tais histórias foram escritas a partir do conhecimento das experiências de vários de seus companheiros de cárcere, o que justifica, então, o título do volume: Vidas do Carandiru Histórias Reais. São "histórias reais" porque, de acordo com Rodrigues, foram construídas a partir daquilo que seus companheiros lhe contaram sobre suas próprias experiências e/ou trajetórias.

Este volume tem importância para esta tese ao trazer, a partir do diário de Rodrigues, uma discussão acerca da produção literária no interior do cárcere. Para além dos apontamentos sobre o presídio - o cotidiano, as regras, a maneira como os presos se relacionam etc. - Rodrigues insere em seu diário questões acerca da produção do livro, apontando para as dificuldades da escrita dentro da prisão, para os sentidos que ela adquire ao longo do cumprimento da pena, para o receio de não conseguir escrever e publicar o livro, assim como para o medo de ter seus escritos destruídos em uma blit:

Sobrevivente André Du Rap (do Massacre do Carandiru), da autoria de André Du Rap (1971-) e Bruno Zeni (1975-), foi publicado pela Labortexto Editorial ${ }^{25}$, no ano de 2002. No

lançou Mil dias de solidão, sobre o governo Collor, em 2001, publicou Memória das Trevas, sobre a vida de Antônio Carlos Magalhães, e em 2011, Privataria Tucana, que aborda os bastidores do governo Serra em São Paulo.

${ }^{25}$ A Labortexto Editorial publicou diversos livros daquilo que ficou conhecido como literatura marginal, muitos deles tratando do tema prisional, como Capão Pecado (2000), de Ferrez, Diário de um Detento (2001), de Jocenir, Cela Forte Mulher (2003) de Carlos Prado, entre outros. 
momento da elaboração e publicação do livro, André Du Rap encontrava-se em liberdade, mas o tema da narrativa é a sua experiência na prisão. O livro é fruto de uma parceria com Bruno Zeni, jornalista e doutor em literatura, responsável pela elaboração do projeto da obra. Interessado no processo de julgamento dos responsáveis pelo Massacre do Carandiru, Bruno Zeni assistiu ao julgamento do Coronel Ubiratã - policial militar responsável pela invasão do presídio e que, em 2001, estava sendo julgado pelas mortes ocorridas - seu intuito era se aproximar de pessoas que tivessem sido próximas às vítimas, de forma a conhecer um pouco a história de alguns deles, num esforço de transformar a memória do evento, baseada em estatísticas ou números (o icônico 111), em um referencial baseado em sujeitos com rostos e nomes (ANDRÉ DU RAP, ZENI, 2002, p.203). André Du Rap participou do julgamento como testemunha de acusação; foi ali então que Zeni travou contato com ele, dando início à elaboração de um livro ancorado na experiência do cárcere. A maior parte da obra é formada pela transcrição, feita por Zeni, de entrevistas por ele realizadas com André, assim como transcrições de falas que André gravou sozinho, sem a intervenção do jornalista, voltadas para a sua experiência prisional. O livro contém, ainda, a publicação de cartas que André enviou a alguns familiares enquanto esteve preso, assim como outras que recebeu no mesmo período, além de fotografias. Ao final, alguns companheiros de André escrevem sobre ele e Zeni finaliza o livro com uma análise sobre a situação prisional brasileira tendo o Massacre do Carandiru como sua pedra de toque.

O livro de André Du Rap e Zeni possui características importantes para a análise que procuro realizar: André, que poderíamos chamar de narrador do texto, não é quem escreve; ele narra oralmente enquanto Zeni ouve, transcreve, traduz e escreve. É possível dizer que André Du Rap é autor, mas ele só o é, no sentido do livro escrito e publicado, a partir da sua parceria com Zeni. A obra permite elucidar questões importantes sobre a produção escrita e a publicação de livros desde o cárcere, tendo em vista seu caráter de dupla autoria, evidenciando as mediações necessárias para que um determinado tipo de escrita - a produção de um livro - ganhe corpo e possa circular entre o dentro e o fora da prisão.

Pavilhão 9, Paixão e Morte no Carandiru, de autoria de Hosmany Ramos (1947-), foi publicado pela Geração Editorial, em 2001, sendo que a primeira edição veio a público pela Gallimard, editora francesa, no mesmo ano. Antes de ser preso, Ramos foi cirurgião plástico famoso no Rio de Janeiro, na década de 1970, tendo feito parte da equipe do renomado médico Ivo Pitanguy. Durante sua formação, na Universidade Federal do Estado do Rio de Janeiro, passou uma temporada nos Estados Unidos, onde estudou literatura americana na 
Universidade de Long Island. Nos anos 1980, foi acusado de envolvimento em diversos crimes, como roubo de carros e joias, tráfico e assassinato, e condenado a 47 anos de prisão. Ramos consagrou-se escritor na prisão; já foram publicados mais de dez livros de sua autoria por editoras brasileiras e francesas.

Ao contrário de Luís Alberto Mendes, Hosmany Ramos possuía intimidade com o universo da leitura e da escrita antes de sua prisão, mas é após o encarceramento que passa a escrever literatura. O volume que nos interessa mais de perto, Pavilhão 9, traz uma sequência de contos que têm como temática as "experiências marginais", principalmente aquelas vividas por pessoas que se encontram presas. Ramos registra o que ele vive na prisão ou aquilo que é vivido por seus companheiros, embora nos textos que fazem parte do volume a ser analisado, nem sempre os personagens se encontrem presos ou se envolvam com a criminalidade. De todo o modo, é a violência e a criminalidade que dão o tom do livro. No prefácio à obra, ele afirma que está falando sobre a realidade, não acrescentando nada a ela; ao mesmo tempo indica que seus contos são ficção. Dentre os vários livros do autor, Pavilhão 9 foi incluído nesta análise por ter o Massacre do Carandiru como pedra de toque, sendo uma narrativa do horror, ao mesmo tempo que se volta para o cotidiano prisional e para as experiências de sujeitos que se encontram às voltas com a prisão e a criminalidade. Tendo sido publicada primeiramente numa editora francesa, em língua estrangeira, a obra permite uma maior complexidade à análise, já que faz com que a escrita do cárcere transcenda muros e fronteiras transnacionais.

Letras de Liberdade foi publicado em 2000 pela Madras Editora ${ }^{26}$, sendo o resultado de um concurso literário realizado em algumas unidades prisionais da Região Metropolitana de São Paulo. O livro conta com a publicação de quinze textos de presos, selecionados dentre os 345 recebidos para o concurso. Os textos agraciados no concurso foram publicados ao lado de outros tipos de escritos: desenhos elaborados por presos, o prontuário de cada autor e um texto final, assinado por uma personalidade no mundo jurídico, artístico ou acadêmico, comentando o texto premiado.

O Direito do Olhar: Publicar para Replicar (2009) foi publicado pelo Instituto de Defesa do Direito de Defesa, organização do terceiro setor voltada para a promoção do direito de defesa. A obra também foi resultado de um concurso realizado em diversas penitenciárias e

\footnotetext{
${ }^{26}$ A Madras se reconhece como uma editora voltada para a publicação e circulação de livros de cunho exotérico e religioso, tendo como objetivo, segundo seu fundador, Wagner Veneziani Costa, a ampliação do conhecimento humano.
} 
instituições socioeducativas na Região Metropolitana de São Paulo. Mas, diferentemente do livro anterior, o volume volta-se ao público feminino (o primeiro dedicava-se a penitenciárias femininas e masculinas) e inclui, além de textos literários, fotografias e desenhos que faziam parte das categorias do concurso.

Esses dois volumes foram resultado de projetos elaborados fora do cárcere e que o tomaram como objeto de atenção. Os textos publicados foram produzidos a partir de uma rede de relações que envolveu os presos, mas também os funcionários dos presídios, as autoridades da prisão, assim como gestores, administradores, editores e outros tipos de profissionais que não se encontravam ligados diretamente ao cárcere. Mesmo que seja possível perceber uma rede complexa na elaboração e publicação dos volumes anteriores, nestes, há uma profusão de atores para a elaboração do próprio texto, e não apenas do livro resultante da ação do concurso. Diferente, ainda, dos volumes anteriores, nestes, os autores participam da elaboração do livro de forma pontual, com apenas um texto, não sendo responsáveis pelo projeto da obra. Este projeto, nestes casos, é algo completamente exterior ao cárcere, tomando-o, apenas, como objeto, mas que passa por ele, toma corpo dentro das grades a partir de uma rede complexa de tensões e jogos de convencimento, para então sair de lá como conteúdo de um livro, que será publicado por editoras fora do cárcere.

O Massacre ocorrido no dia 2 de outubro de 1992 no Carandiru é o evento crítico que deflagrou as narrativas que analiso ao longo da tese. Mais que tratar do Massacre, tais relatos pautam-se, principalmente, na experiência no cárcere e nas relações construídas de modo que a vida fosse possível naquele ambiente. O evento crítico gera, assim, uma série de narrativas que tratam não apenas da violência e do horror envolvidos no evento Massacre, mas também das estratégias e agenciamentos mobilizados para que o cotidiano na prisão fosse possível, apontando, ainda, para práticas que transformam o cárcere num lugar que atravessa física e simbolicamente seus muros e alcança a sociedade que se encontra fora dele.

Sobrevivente André du Rap (do Massacre do Carandiru) e Pavilhão 9, Paixão e Morte no Carandiru são as obras analisadas no primeiro capítulo, intitulado Massacre, violências, memórias: dois modos de narrar. Estes livros têm sua origem no Massacre, mas extrapolam o evento crítico ao chamarem atenção para o cotidiano na prisão, para as relações humanas tecidas e reconstruídas cotidianamente no espaço do cárcere. Falar do Massacre é também falar dos mortos e pelos mortos, é dar nomes a eles e lutar contra uma objetificação imposta pelo sistema prisional tanto àqueles que morreram, quanto àqueles que sobreviveram e sobrevivem, cotidianamente. O Massacre faz emergir narrativas que dão conta do evento 
crítico, ao mesmo tempo que fazem circular a prisão por meio de enredos outros que não a tragédia. Este capítulo será pautado na tensão presente nos textos dos cárcere entre a necessidade de relatar o horror e o desejo de fugir da tarefa de narrá-lo, tensão expressa na maneira como os volumes se estruturam, tomando o Massacre como ponto de partida - como aquilo que chama a atenção para a prisão - para então voltar-se para outros temas, também típicos da prisão, mas que antes da tragédia não recebiam a atenção do público leitor exterior ao cárcere.

Luiz Alberto Mendes e Humberto Rodrigues são os autores de Memórias de um Sobrevivente e Vidas do Carandiru, Histórias Reais, respectivamente. Essas são as obras que serão analisadas no capítulo 2, intitulado A prática da escrita no cárcere e a produção de sujeitos bumanos, momento em que procuro compreender a (re)construção do sujeito no cárcere a partir da elaboração de um livro. Os autores do cárcere, por meio da prática da escrita, inauguram um discurso interessado em uma reelaboração das interpretações vigentes sobre o sujeito preso, as quais determinam um entendimento sempre negativo, valorizando suas faltas e falhas, em detrimento daquilo que os colocaria na mesma esfera que os demais sujeitos, os não presos. A análise de tais obras elucidará as tensões presentes na literatura do cárcere acerca daquilo que Judith Butler (2015) chamou de produção de "enquadramentos": se a sociedade produz continuamente os parâmetros pelos quais os indivíduos irão interpretar e reconhecer (ou não reconhecer) o "outro" (os "enquadramentos"), os escritos do cárcere buscam reestabelecer tais parâmetros de modo a incluir nesse reconhecimento (um reconhecimento do "humano") o sujeito preso. Juntamente com o livro, que nasce no cárcere e circula para fora dele, temos também discursos que circulam e transformam o que se encontra fora da prisão a partir de uma prática que se dá ali dentro.

Por fim, analiso, no capítulo 3, cujo título é Concursos prisionais: ressocialização e resistências, alguns volumes que foram resultado de concursos literários e artísticos em prisões paulistas. A análise de Letras da Liberdade e O Direito do Olhar lança luz sobre uma outra esfera dos textos prisionais que extrapola a poética: esses textos são eminentemente instrumentos políticos. A prática da escrita, aqui, se dá dentro de um jogo de forças em que os idealizadores dos concursos estipulam as regras e seus objetivos, e o fazem a partir de um lugar externo ao cárcere. Os participantes, por sua vez, produzem textos que serão avaliados por agentes internos e externos ao cárcere, tendo em vista o caráter de ressocialização que a escrita no cárcere assume para a instituição prisional, que também exerce um papel de avaliação sobre os textos. Escrever, neste caso, é atestar para a sociedade uma mudança por 
parte dos autores. Os textos produzidos - avaliados, premiados e publicados - carregam em si diversas nuances que são as marcas desses jogos de opressão, resistência e convencimento.

O corpus desta tese, formado por livros do cárcere, mais que oferecer um mapa da produção literária prisional a partir do Carandiru, tenta oferecer uma compreensão outra sobre as maneiras pelas quais o cárcere se insere na sociedade, sendo determinado por ela, ao mesmo tempo em que modifica seu estatuto continuamente, indo na direção contrária do enclausuramento e anulação dos sujeitos ali enclausurados. Tais materiais nos relevam um tipo de comunicabilidade entre o cárcere e a sociedade voltada para as formas de pensamento e de interpretação do sujeito, do outro, da sociedade, do poder e da própria prisão. Para além do livro que circula, a prisão circula por meio dele. 


\section{CAPÍTULO 1}

\section{MASSACRE, VIOLÊNCIAS, MEMÓRIAS: DOIS MODOS DE NARRAR}

A memória sobre o Massacre do Carandiru - a recordação sobre o evento e a reconstrução da vida cotidiana - foi sendo construída juntamente com a elaboração de um imaginário sobre a prisão. Apesar desta elaboração conjunta, é possível dizer que o Massacre é o evento catalisador de narrativas sobre a prisão, funcionando como um tropos do imaginário social sobre o cárcere. Isso é o que nos permite compreender a leitura de dois livros: Sobrevivente André du Rap (do Massacre do Carandiru) e Pavilhão 9 - Paixão e Morte no Carandiru, de Bruno Zeni e André du Rap, o primeiro, e Hosmany Ramos, o último, volumes que serão analisados neste capítulo.

O Massacre, enquanto um evento crítico, proporciona a base a partir da qual várias memórias podem ser construídas. Ao se debruçar sobre as técnicas de meditação monástica medieval em busca da construção de imagens do pensamento, Marry Carruthers (2011) sugere que a memória não é algo estático, nem mesmo funciona como um simples acúmulo de recordações, antes, são tropos, lugares a partir dos quais as pessoas constroem recordações e também entendimentos e interpretações, o que aponta para o caráter inventivo da memória. Este conceito de memória como "res" - uma memória que "faz" coisas - me parece bastante útil para pensarmos o Massacre não apenas como um evento, mas como um lugar da memória.

O Pavilhão 9, local da tragédia, ficou completamente destruído; depois que os sobreviventes carregaram os cadáveres e lavaram os pavimentos, todos foram encaminhados 
para o pátio, sentados e enfileirados, nus e com as cabeças abaixadas por entre as pernas, formando uma das imagens mais icônicas do Massacre ${ }^{27}$.

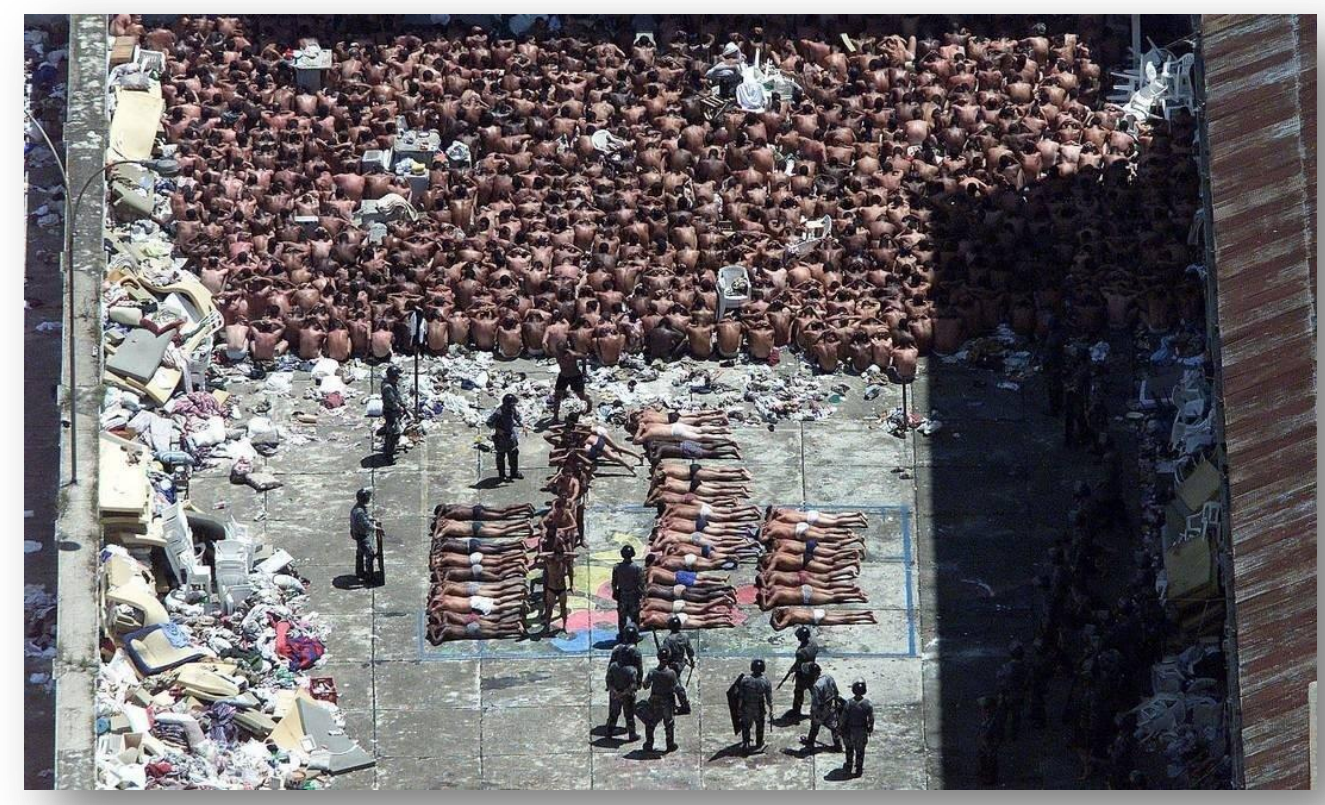

Figura 1.1: "Relembre em imagens o Massacre do Carandiru”, Arquivo O Globo.

\section{Fonte: Jornal $\boldsymbol{O}$ Globo.}

Se a imagem da quadra de cimento tomada por fileiras de homens nus, com as cabeças baixas entre os joelhos, rodeados por policiais, expressa e sintetiza a ideia do Massacre para muitos (e para mim mesma), para aqueles que formaram essas fileiras, o evento seguramente produziu outras imagens, remetendo a outros lugares e sentidos. A experiência do Massacre cria um entendimento diverso e, portanto, uma memória diferente para aqueles que o vivenciaram, como não poderia deixar de ser. É tentando perscrutar essas significações outras que passo a analisar os volumes mencionados, tomando-os como narrativas que

\footnotetext{
${ }^{27}$ Esta é, por sinal, a imagem que primeiro me remete ao Massacre do Carandiru. Sendo ainda criança quando o evento ocorreu (eu tinha em torno de 10 anos), a imagem mental que se formou em mim eram as fileiras de homens nus, que eu achava que eram os 111. Imagem que também me vinha à mente quando ouvia a música de Gil e Caetano, Haiti: "E quando ouvir o silêncio sorridente de São Paulo / diante da chacina / 111 presos indefesos, mas presos são quase todos pretos / ou quase pretos, ou quase brancos quase pretos de tão pobres".
} 
partem do Massacre e a partir dele constroem entendimentos diversos não apenas sobre a tragédia, mas sobre a experiência prisional mais ampla.

\subsection{UM MEMORIAL AOS MORTOS: O MASSACRE COMO UM MAPA PARA A MEMÓRIA}

José André de Araújo e Milton Marques Viana estavam presos no Pavilhão 9, no Carandiru, no dia em que a Polícia Militar recebeu ordens superiores para invadir o presídio e abafar uma suposta rebelião, operação que culminou, oficialmente, na morte de 111 presos. José André e Milton Marques não fizeram parte das estatísticas dos mortos, mas engrossaram as fileiras dos feridos, que ultrapassaram a cifra de 400. Ambos são sobreviventes sobreviventes do Massacre - como muitos outros.

José André de Araújo, conhecido como André du Rap, elaborou com o jornalista e doutor em literatura, Bruno Zeni, uma narrativa sobre o Massacre, pedra de toque do livro publicado pela Labortexto Editorial, no ano de 2002, que faz referência já no título à figura do sobrevivente: Sobrevivente André du Rap (do Massacre do Carandiru). Milton Marques, por sua vez, relatou sua experiência como sobrevivente ao Massacre para o escritor e presidiário Hosmany Ramos, que se ocupou de transformar este relato em uma narrativa publicada como conto no livro Pavilhão 9 - Paixão e Morte no Carandiru, sendo que o conto leva o mesmo nome do livro, publicado em 2001 pela Geração Editorial2 ${ }^{28}$.

O Massacre e os sobreviventes que narram a trágica história vivida aproximam, de alguma forma, os livros em questão. No livro de André du Rap e Bruno Zeni, o próprio título reforça a ideia do Massacre e o narrador como sobrevivente; já no volume assinado por Hosmany Ramos, embora o título traga apenas o nome do pavilhão onde ocorreu o Massacre,

\footnotetext{
${ }_{28}$ Apesar de os dois volumes contarem com parcerias em suas elaborações, estas são de naturezas distintas: em Sobrevivente André Du Rap, Bruno Zeni e André Du Rap trabalham juntos na elaboração do livro, sendo que André é responsável pelo conteúdo da narrativa e Zeni atua, principalmente, no trabalho de edição. Já em Pavilhão 9, apenas o último conto do livro, que leva o mesmo título do volume, é produzido por uma parceria entre Milton Marques Viana e Hosmany Ramos. Neste caso, Viana narra sua experiência a Hosmany Ramos, que a transforma em uma das narrativas que compõe seu livro de contos, a parceria presente, portanto, apenas no texto, no interior do livro, que toma o Massacre como tema.
} 
a capa e contra capa mostram a foto de dois corpos nus, mortos, estirados no chão e com sinais de ferimentos à bala, no abdômen e nas costas, o que remete ao Massacre.
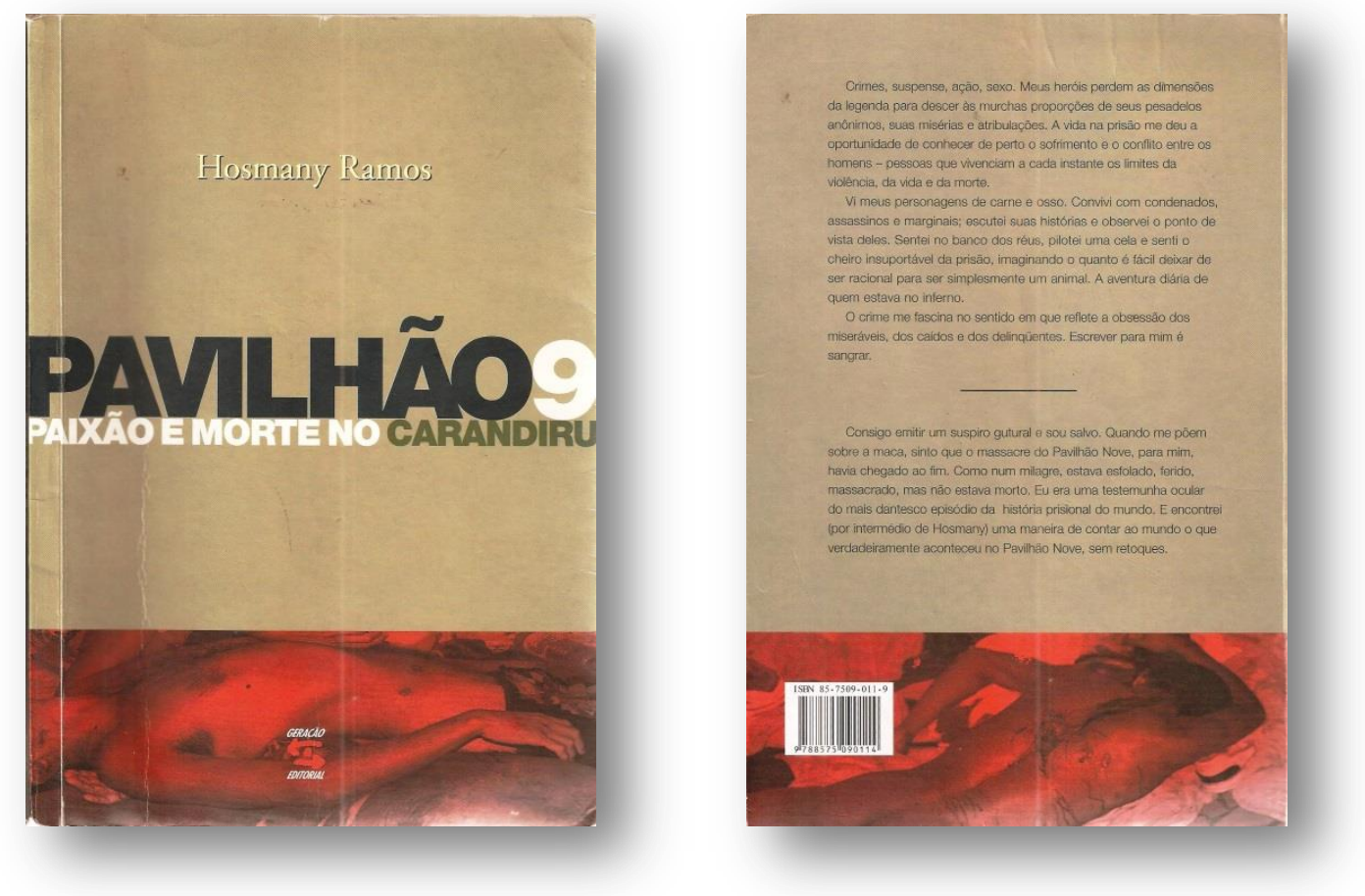

Figura 1.2: Capa e contra capa do livro Pavilhão 9, Paixão e Morte no Carandiru, de Hosmany Ramos, Geração Editorial, 2001, Capa: Victor Burton.

André du Rap e Milton Marques não foram os únicos a relatarem, em forma de livro, os acontecimentos daquele 2 de outubro. Há um grande número de narrativas daquele evento, elaborados a partir de formas diversas, buscando dar conta da sequência dos acontecimentos e dos sentidos construídos para que viesse a ocorrer, como assinalamos antes. Mas o que chama a atenção nesses dois relatos é o seu caráter de testemunho, pois se voltam para a experiência vivida do evento, que os converte em sobreviventes.

Ao se colocarem a tarefa de narrar a tragédia que assolou o Pavilhão 9 naquele dois de outubro, André du Rap e Milton Marques dão início à narrativa lembrando-se, em 
primeiro lugar, daqueles que morreram ao lado de cada um: apesar do número de vítimas ter sido contabilizado pouco tempo depois do evento, a memória sobre os 111 mortos não foi elaborada de uma só vez. As narrativas do Massacre e a nomeação dos mortos foram sendo construídas ao longo do tempo; passar do tempo que, como sugere Veena Das (2011) possibilita a reconstrução dos espaços, a elaboração de narrativas e a recuperação da experiência. O lugar da desolação volta, assim, a ser habitado por aqueles que sobreviveram ao terror; é neste lugar que o cotidiano precisa ser reconstruído, tornando a vida - e suas relações - novamente possível. Essa reconstrução se faz por meio das narrativas em que os sobreviventes constroem, em primeiro lugar, um espaço para relembrar os mortos. Ao retornarem ao lugar da desolação, eles contam histórias, relatam aquilo que viram e ouviram, juntam fragmentos e procuram criar uma ideia de conjunto: um morto que se junta a outro, um nome que é lembrado ao lado dos demais, corpos que vão sendo identificados, um a um. O Massacre ganha corpo e forma ao ser transformado em narrativa.

Milton Marques comemorou, em 2 de outubro de 1995, três anos de sua nova vida. Já na Penitenciária de Avaré, para onde foi transferido depois do Massacre, conheceu Hosmany Ramos, que ali se encontrava. Marques pede, então, a Ramos que escreva a sua história, a sua história do Massacre. Passaram-se três anos para que a narrativa de Marques fosse construída ${ }^{29}$. A memória de sua experiência junta-se a outras memórias, de outros presos sobreviventes e assume o caráter de testemunho, já que Marques se coloca como um porta-voz daqueles que não sobreviveram e, mais do que isso, sua narrativa deveria se converter em instrumento de produção de memória, arma contra o esquecimento, é o que pode se depreender de sua fala, que assume a forma textual a partir da escrita de Hosmany Ramos: "Não sei por que Deus salvou minha vida, quando todos os meus companheiros de xadrez morreram. Senti-me na obrigação de contar minha versão. Não para criticar o sistema, mas para alertar futuras gerações e prevenir novos massacres” (RAMOS, 2001, p.230).

Os sobreviventes do Holocausto se colocam diante de um questionamento similar ao enunciado por Marques, como sabemos. Os estudos sobre a literatura de testemunho mostram que uma das marcas do relato traumático dos sobreviventes do genocídio judeu é uma espécie de culpa por não terem sucumbido à mesma sorte de seus companheiros, como

\footnotetext{
${ }^{29}$ Para Veena Das (2011), o passar do tempo é algo fundamental para que as narrativas do horror possam ser elaboradas, tendo em vista que é ao longo do tempo que o entendimento sobre as experiências dolorosas vai sendo construído e compartilhado, o que permite, então, a elaboração das narrativas. Já Fassin e Rechtman (2009), ao se voltarem para a noção de trauma, afirmam que a memória do trauma só se constitui em um momento posterior, em que o indivíduo que sofreu uma experiência limite consegue interligar a sua experiência individual à memória coletiva. O passar do tempo, portanto, é um elemento fundamental, segundo esses autores, para a elaboração das narrativas e da memória sobre o evento trágico.
} 
afirma Selligman-Silva (2008, p.75). Nesse sentido, narrar o trauma é sempre narrar pelos outros, em nome dos outros, daqueles que não sobreviveram e por isso mesmo não podem falar. A culpa, no entanto, coloca o relato desses sobreviventes sob relativa suspeita: de quem é a narrativa? De quem é a experiência relatada? É aquela do próprio sobrevivente? Ou a de outros que não podem mais falar?

André du Rap recorre à divindade para dar sentido ao fato de sua sobrevivência. Deus, portanto, é acionado para conferir sentido àquilo que parece aleatório: por que uns morreram e outros não? Em suas palavras:

Acho que Deus tinha um propósito na minha vida, um propósito em me tirar daquele lugar, como na vida de muitos companheiros que também sobreviveram. Teve um momento em que os policiais atiravam e não saía mais bala. Eles apertavam o gatilho das metralhadoras e só patinava, não saía mais nada. Foi um milagre. Naquele momento, Deus colocou a mão sobre várias cabeças, olhou por nós. Acho que foi a mão de Deus que salvou a vida de muitos ali. Acho que Deus quis resgatar algumas pessoas e mostrar que a mão Dele é mais forte que a mão do homem (DU RAP, ZENI, 2002, p.26-27).

Ao explicar a sobrevivência pela eleição divina, André du Rap resolve, de certa forma, a questão da culpa relatada por Selligman-Silva em relação aos sobreviventes do Holocausto: foi Deus quem escolheu os vivos e os mortos. Mas ao se reconhecer como um eleito, André se vê diante do dever de falar sobre os mortos e pelos mortos.

Às vezes me vejo naquele dia, lembro de como começou, um amigo de cela falando, alguém dizendo:

- Ô, André, hoje é seu aniversário, mano! Segunda-feira eu vou embora, vou mandar um presente pra você aí, de lá de fora.

Esse amigo morreu na minha frente, tomou mais de 18 tiros de metralhadora na minha frente. Vi o cara caído e não podia fazer nada. Tinha companheiro ali, como ele, que tava pra sair. [...] É um pedaço da minha vida e eu tenho que estar aberto para falar disso. Foi um fato que aconteceu e está escrito na história do país (DU RAP, ZENI, 2002, p.26).

Milton Marques afirma que é preciso falar sobre o Massacre para que ele não se repita. André, por sua vez, diz que aquilo que viveu faz parte da história do país. Narrar, portanto, é 
construir um futuro em que massacres não mais aconteçam; é falar pelos outros, aqueles que morreram; é contar a história do país. Depois de oferecerem uma justificativa para suas narrativas - oferecendo um sentido específico ao relato que produzem - os autores passam a contabilizar os mortos, nomeando-os e localizando suas mortes, como forma de dar corpo à tragédia, construindo um novo lugar de memória: um memorial aos mortos.

Para os sobreviventes do Massacre, o retorno ao Carandiru contou com a presença de uma memória dolorosa - a memória do Massacre -, mas também com inúmeras ausências: a ausência daqueles que morreram. Os corpos foram contabilizados já no primeiro dia depois da tragédia: 111 mortos. Estes corpos, levados ao IML, foram abertos, sofreram a autópsia e receberam um número (ironicamente, como os presos vivos recebem um número, os mortos do Carandiru também receberam) e ficaram à espera de algum reconhecimento, para que se tornassem, então, pessoas, pessoas mortas, certamente, mas com um nome. A partir dos números, temos apenas cadáveres, como sugere Thomas (1989); é a partir do reconhecimento dos familiares que os cadáveres se tornarão corpos - corpos ligados a um sujeito - e poderão, finalmente, ser velados ${ }^{30}$.

\footnotetext{
${ }^{30}$ Há relatos de agentes prisionais que trabalhavam no Carandiru à época, assim como de sobreviventes ao Massacre, de caráter não oficial, de que o número de mortos foi maior que os 111. Os mortos não contabilizados seriam aqueles que ninguém reclamou a morte: presos de outros estados, de lugares distantes de São Paulo, que os familiares não puderam reclamar. Sobre estes corpos e essas mortes, nada se pode dizer, nada se pode saber ao certo.
} 


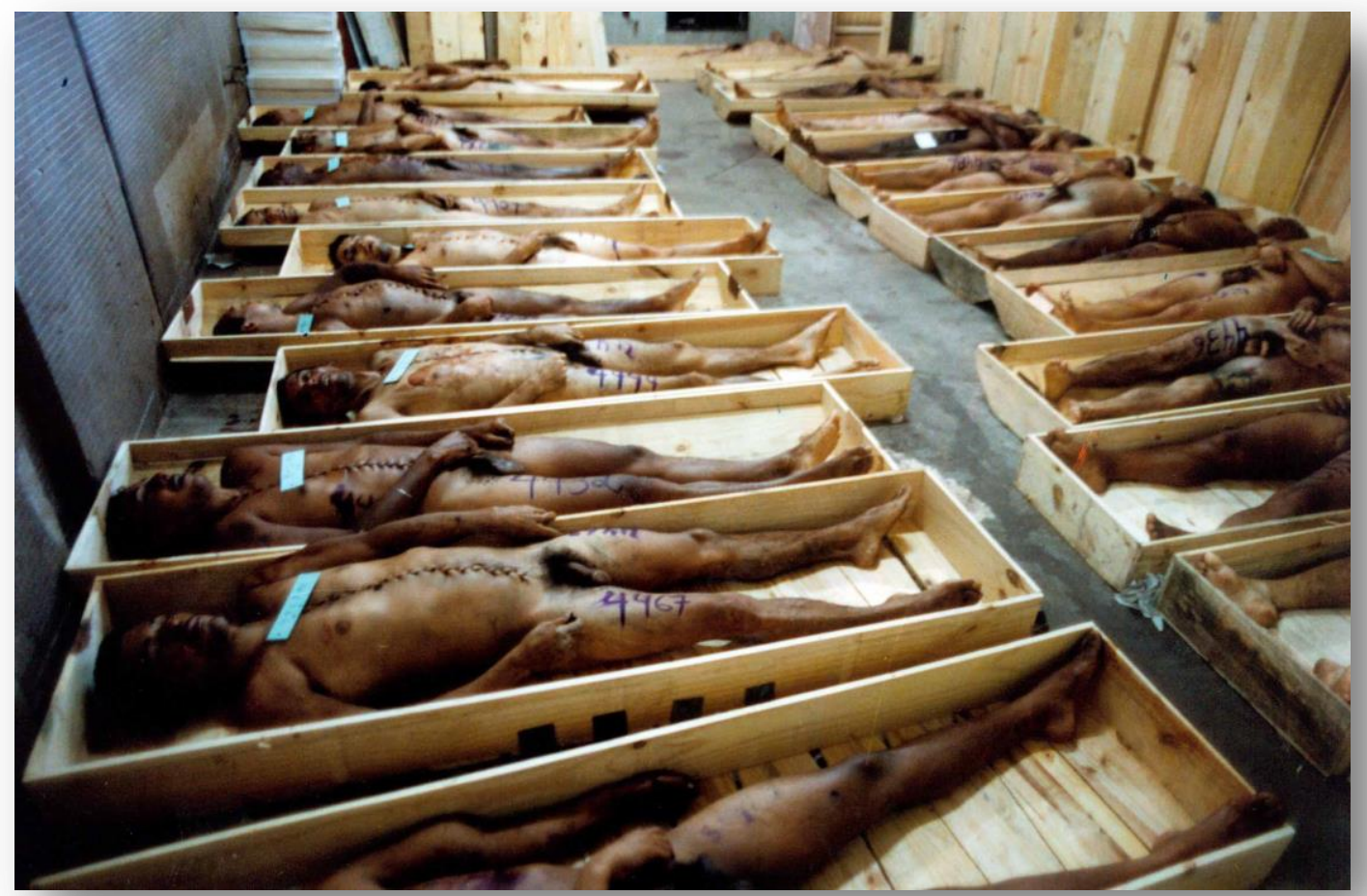

Figura 1.3: Corpos de presos massacrados pela PM, na Casa de Detenção (Carandiru), foram autopciados no IML.

Foto: Epitácio Pessoa/AE, fonte: Estadão, Blog Roldão Arruda, 10/1/2014.

Depois de receberem números, se inicia então o difícil trabalho de identificação dos corpos. Durante a rebelião, familiares de presos ficaram de prontidão ao longo de todo a tarde e noite no portão da Casa de Detenção. As informações que receberam eram de que apenas oito presos haviam sido mortos durante a intervenção da PM, como noticiou o jornal O Globo ${ }^{31}$. Assim que os números oficiais foram divulgados, os familiares precisaram, então, buscar seus parentes - filhos, maridos, pais - entre os vivos e os mortos. Jacy Lima de Oliveira, outro sobrevivente do Massacre, afirma, em entrevista ao portal G1 no dia 2 de outubro de 2012, quando o evento completou 20 anos, que até aquele momento, havia

\footnotetext{
31 "No dia do Massacre, as autoridades divulgaram que apenas oito presos morreram no Carandiru", disponível em: https://oglobo.globo.com/brasil/relembre-em-imagens-massacre-do-carandiru-8056011. Acesso em $22 / 5 / 2018$.
} 
famílias procurando os filhos no sistema carcerário, já que os números oficiais não deram conta de todas as mortes ocorridas no Massacre ${ }^{32}$.

Ao retornarem à Casa de Detenção, após curto período de recuperação em hospitais paulistas, os presos sobreviventes foram alocados em outros pavilhões, e é então que iniciam o doloroso trabalho de reconhecimento dos ausentes, relatando o que viram e viveram, relembrando os mortos e suas mortes. Mortos que vão sendo reconhecidos a partir da ausência (não porque agora se encontram livres, como seria o caso do companheiro de André Du Rap, que sairia em liberdade na semana seguinte do Massacre e que foi morto pelos policiais, como visto no excerto de André Du Rap, acima); não há, ali, a presença de corpos a serem velados, apenas a lembrança dos companheiros sendo atingidos por tiros, facas, socos, pontapés e mordidas de cachorro. O retorno ao Carandiru é, assim, a chegada a um lugar de ausência.

E é no espaço-tempo composto pela falta que são construídos memoriais e narrativas, que versam sobre os mortos e os vivos; sobre o lugar da ausência e também o cotidiano que deve ser reconstruído; sobre as vidas que prosseguem e o mundo possível que passam a habitar (DAS, 2005). Milton Marques contabiliza os mortos e mortes, narrando o local e a maneira como seus companheiros foram mortos:

O policial ferido começa a gritar dizendo que foi atingido por uma bala disparada por um dos presos. Estouram a porta do xadrez 252-E e metralham todos. Alexandre Nunes, Carlos Silvano, Cláudio Carvalho, Douglas Brito, Émerson Pontes e Grinário Valério estavam mortos e silenciados (RAMOS, 2001, p.254 e 255).

Os mortos, no relato de Milton Marques, possuem nome e sobrenome, tão diferentes dos números marcados sobre a pele dos cadáveres, e distintos também da maneira como foram tratados no momento de suas mortes; diz André du Rap:

32 Portal G1, "Estou vivo por um milagre", 2/10/2012, disponível em: http://g1.globo.com/saopaulo/noticia/2012/10/estou-vivo-por-um-milagre-diz-sobrevivente-do-carandiru.html. Acesso em 20/9/2017. 
Eles [os policiais] gritavam:

- Vai, ladrão! Vai, zé! Corre, corre, filho da puta! - não chamavam a gente por nome, não, era só 'zé', 'ladrão', xingando - 'filho da puta!'.

$[\ldots]$

- Tem alguém ferido? - eles perguntaram uma hora.

- Eu, eu...

- Ah, é?, ladrão, você não morreu ainda, não? Então toma.

E atiravam na cabeça, no peito.

(DU RAP, ZENI, 2002, p.22-23).

Milton Marques, o narrador do texto de Ramos, prossegue com a narrativa do Massacre, continuando a dar nomes àqueles que foram atingidos pelos PMs:

Outro xadrez em frente é invadido. Balas de grosso calibre perfuram colhões e tiram lascas das paredes. Jorge Sakai, José Marcolino, Luiz Granja, Marcos Sérgio, Mauro Batista e Reginaldo Judici saem apavorados com as mãos para cima. Luiz Granja é atingido a queima roupa e o impacto joga-o no canto da parede. Ele cai e estrebucha como uma ave degolada (RAMOS, 2001, p. 254).

$\mathrm{Na}$ narrativa de Marques, nomes e sobrenomes associam-se a sujeitos levando tiros, rajadas de metralhadora, baionetadas etc. Ao final do texto, estes figuram numa lista, em ordem alfabética, numerados do um ao cento e onze. A mesma lista que foi lida por vinte e quatro horas pelos performances e por Nuno Ramos no ato público nomeado de Vigília 111. A mesma lista que se transformou em 111 cruzes fincadas no chão à frente da Faculdade de Direito Largo de São Francisco, em oito de abril de 2013, dia em que estava previsto o julgamento de 26 dos 79 policiais acusados pelo Massacre. 


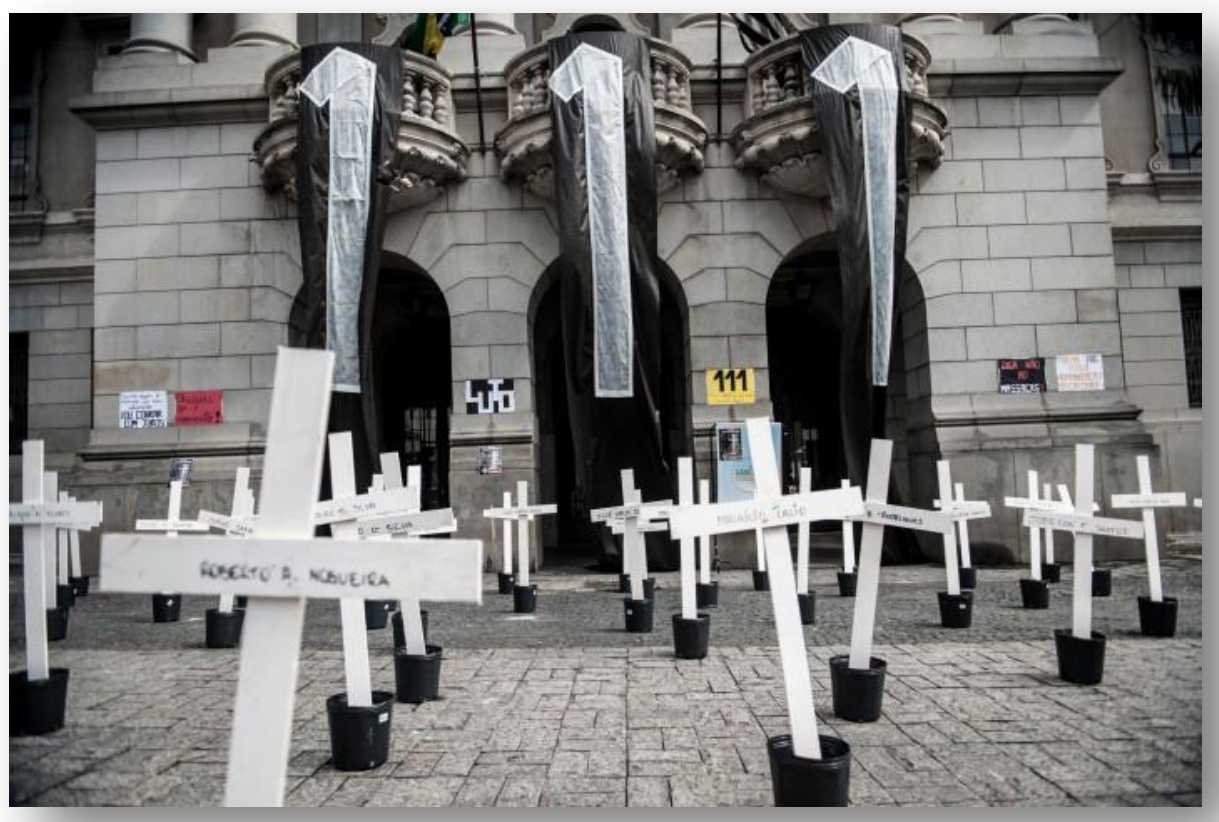

Figura 1.4: Cruzes instaladas pelos estudantes de direito da Universidade de São Paulo (USP), em frente ao prédio da faculdade, no centro da capital, para lembrar o número de presos mortos por policiais militares na Casa de Detenção do Carandiru, em 1992. Foto de Marcelo Camargo/ABr, Portal EBC.

A lista lida pelos artistas por vinte e quatro horas ininterruptas, ou as cruzes com os nomes dos 111 presos mortos à frente da Faculdade de Direito da USP, e outros monumentos aos mortos do Massacre, buscam construir uma memória social frente a um escândalo do sistema prisional brasileiro, descartando a possibilidade do esquecimento, fazendo lembrar. Tanto a lista quanto as cruzes não dizem nada sobre a subjetividade daqueles que morreram, não os identificam enquanto sujeitos, não conferem a eles um rosto ou uma história. Relembrar os mortos, dessa forma, é ação voltada para o futuro: buscar compreender um número - 111 - e recordá-lo para que não seja esquecido e que não volte a acontecer. É Goody (2012) quem nos ensina que as listas são categorizações escritas que não se relacionam à linguagem oral, como à primeira vista tendemos a pensar. Ao contrário, a lista faz justamente o que a fala não pode fazer, sendo voltada para registros numéricos, de eventos ou pessoas. A lista não é, portanto, uma representação, mas um registro, indica o autor. A lista dos nomes das vítimas do Carandiru, reiterada em contextos diversos, longe de 
representar e ou descrever, registra, inscreve; devendo ser compreendida como uma categorização, e não como narrativa ${ }^{33}$.

De modos distintos, as lista e as narrativas fazem lembrar. A lista enumera, contabiliza, e ao fazê-lo permite a construção de um lugar da memória a partir do qual diferentes atores constroem entendimentos diversos sobre o evento. A narrativa, por sua vez, apropria-se deste lugar da memória a partir de uma experiência pessoal, dando sentido aos nomes presentes na lista, indicando suas histórias, emoções, os lugares ocupados no momento de suas mortes, os amigos presentes, que compartilhavam o mesmo terror, como nos mostram as narrativas do Massacre, descritas por André Du Rap e Hosmany Ramos, quando este dá voz à Milton Marques. Tanto a lista quanto a narrativa, enquanto lugares da memória, não se encontram no passado, mas fornecem as bases para a elaboração criativa de um presente e um futuro. Para Milton Marques e André du Rap (e outros sobreviventes) lembrar os mortos é construir um presente possível, é poder voltar a viver no lugar da desolação e do horror; implica contabilizar as ausências, compreender o caminho da bala que atingiu o colega ao lado mas que lhes poupou da morte. Narrar os mortos é falar por eles, é lembrar também que eles estariam ausentes dali a uma semana, não pela morte, mas pela liberdade a ser alcançada. Lembrar os mortos é dar nome aos cadáveres, é garantir o direito ao luto, afirmando que esses homens - aos quais as designações de ladrões, traficantes, assassinos e outras homogeneízam e despersonificam - são seres humanos e merecem ter suas mortes lamentadas.

\footnotetext{
33 A lista dos nomes dos mortos do Carandiru, enquanto um dispositivo de memória, assemelha-se ao Memorial do Vietnan, monumento aos mortos na Guerra do Vietnan, erguido na cidade de Washington, DC, descrito por Carruthers (2011), que se apresenta como uma lista infindável de nomes de pessoas que morreram na guerra em questão, inscritos em um enorme muro. A autora usa este memorial como um exemplo daquilo que ela chama de "memória rerum", a memória que faz coisas a partir de materiais dados. A lista, no caso do Memorial do Vietnan, mas também no Massacre do Carandiru, funciona como um dispositivo de memória a partir do qual diferentes leitores acessam recordações diversas, construindo uma memória pessoal a partir de uma imagem socialmente produzida.
} 


\subsection{A NARRATIVA dO CÁRCERE: ESCRITA, COTIDIANO E VIOLÊNCIA NA EXPERIÊNCIA PRISIONAL}

Os dois volumes que interessam de perto a este capítulo, produzidos pelas parcerias entre André Du Rap e Bruno Zeni - Sobrevivente André du Rap (do Massacre do Carandiru) - e Hosmany Ramos e Marques Viana - Pavilhão 9: Paixão e Morte no Carandiru - têm no Massacre o elemento catalizador de narrativas; estas, no entanto, são construídas de modo a refletir sobre temas diversos oriundos da prisão, não se restringindo apenas à trágica experiência do horror, embora ela funcione como referência. É essa apropriação do Massacre, de modo inventivo, por meio da qual os autores criam coisas novas (novos temas da prisão, por exemplo) que faz com que os volumes em questão se mostrem ricos do ponto de vista da análise que me interessa realizar.

Logo no início do livro, Zeni esclarece como se deu a parceria para a produção do volume: o jornalista realizou uma série de entrevistas com André, com o intuito de que ele narrasse sua experiência prisional. Tais entrevistas foram gravadas e transcritas por Zeni que organizou, então, o material. A seção que abriga esse material corresponde à primeira parte do livro e recebeu o nome de Depoimento. Além das entrevistas, há uma seção intitulada Free Style, momento em que André fala livremente para um gravador, sem a intervenção de Zeni. Ao lado delas, encontramos outro segmento que contém cartas - escritas por André e também algumas que ele recebeu enquanto se encontrava preso. Finalmente, na última parte, intitulada Aliados, foram reunidos depoimentos de companheiros de André, sobre ele.

Ao editar o conteúdo fornecido pela narrativa de André, Zeni preocupou-se em ser fiel à fala do rapper, afirmando não ser possível separar a forma e o conteúdo daquilo que se diz, se escreve ou cria (DU RAP, ZENI, 2002, p.9). Nesse sentido, o livro, resultado do trabalho de edição de Zeni a partir dos depoimentos de André, apresenta um texto com diversas marcas de oralidade, sem preocupações demasiadas com os registros formais da língua. Apesar da pouca intervenção de Zeni, ele realizou uma mudança importante na ordem da narrativa: "Não alterei a sequência da fala, exceção feita à parte em que André du Rap faz o relato do desenrolar do Massacre do Carandiru, que desloquei para o começo do 'Depoimento"' (DU RAP; ZENI, 2002, p.9, grifo nosso). Assim que no relato de André, o Massacre não se encontra no início. Quando ele propõe narrar sua trajetória, tendo em vista 
sua experiência prisional, não é o Massacre que dispara a narrativa e nem mesmo a história; o trecho foi deslocado por Zeni para o início, de modo que o livro começa pelo relato do Massacre. Observamos ainda que, no final do volume, encontra-se um pequeno ensaio, assinado por Zeni, em que ele analisa diversas questões relacionadas à literatura de testemunho, tendo como pedra de toque o Massacre do Carandiru. Neste trecho fica explícito o interesse deste autor em compreender a tragédia que aconteceu no Carandiru à luz da experiência daqueles que a vivenciaram e sobreviveram, o que chama a atenção para os interesses diversos que orientaram a produção do volume.

Enquanto André volta-se para sua trajetória - que passa pelo Massacre mas não é por ele definida nem delimitada -, Zeni parece mais afeito à compreensão do evento a partir do ponto de vista daqueles que o experimentaram. Como editor, que determina a forma final do livro, ele traz o relato do Massacre para o início do texto; André, por sua vez, discorre sobre outros temas que não se relacionam diretamente com ele: relações familiares, trajetória antes de ser preso, necessidades físicas e emocionais vivenciadas na prisão, a escrita, os companheiros, o rap e as poesias, as injustiças do sistema prisional etc. É nesse sentido que Rita Palmeira (2009) indica a existência de uma dualidade autoral do livro Sobrevivente André du Rap, resultado da "convergência de duas urgências narrativas de origem diversa" (PALMEIRA, 2009, p.85), o que dota o volume de uma forma "híbrida". Segundo ela, André revela a urgência de testemunhar sua experiência; Zeni, por sua vez, deseja dar "rosto" aos 111 mortos no Massacre (DU RAP, ZENI, 2002, p.79).

O Massacre, portanto, apresenta-se como o elemento que dá origem ao livro, sendo o tropos que organiza a narrativa editada em sua forma final, mas, na narrativa de André, ele é mais um dos eventos (trágicos) que marcam sua trajetória dentro do sistema prisional. $\mathrm{O}$ Massacre, que funciona como lugar de origem da narrativa do livro, opera como elemento catalizador dos interesses dos que estão fora do cárcere. É ele que confere a André o estatuto de sobrevivente - título escolhido para o volume -, e faz com que sua narrativa, ancorada em uma experiência específica, alcance a sociedade mais ampla.

Seguindo as sugestões de Fassin e Rechtman (2009), é possível dizer que a tragédia ocorrida no Carandiru transforma sujeitos, antes reconhecidos apenas como "criminosos", em vítimas e que, por isso, passam a merecer cuidado, atenção e tratamento do Estado. Mas, ao contrário do que apontam os autores sobre outros eventos e outras "vítimas humanitárias" (eles têm em mente as vítimas das guerras contemporâneas, assim como os exilados e refugiados que elas produziram), os sobreviventes do Massacre ainda esperam a 
ajuda do Estado: tanto os sobreviventes quanto os familiares dos 111 presos assassinados. De toda a forma, o caráter de "sobreviventes" garante a eles, ou pelo menos a alguns deles, um novo lugar na sociedade, legando-os atenção inédita da opinião pública.

O livro de Hosmany Ramos também extrapola a temática do Massacre, voltando-se para pequenas narrativas em que a vida "marginal" - dentro e fora do cárcere - é retratada de forma a chamar a atenção para a violência. Esta é a temática não apenas de Pavilhão 9, mas dos livros de Ramos em geral, que estão ancorados na vida na prisão, a sua e de seus companheiros. Assim como seus textos não se restringem à sua experiência exclusiva ${ }^{34}$, tampouco se resumem ao espaço da prisão: ao falar a partir do cárcere, ele trilha caminhos que o levam para longe dele, embora sempre referidos às grades ${ }^{35}$; sua fala é a do de crime, das obsessões, do poder e, sempre, da violência.

Pavilhão 9 é composto por vinte e quatro contos, entre eles aquele que leva o título do volume, que dá voz à Milton Marques Viana e descreve a sua experiência do Massacre. Os demais títulos do volume tematizam outras questões que trespassam a vida prisional, o que mais uma vez nos faz perceber o Massacre como um evento que permite a construção de um entendimento social sobre a prisão, inaugurando uma relação específica - pautada na memória - entre o dentro e o fora do cárcere, já que leva para fora tanto a memória quanto a experiência, não só do Massacre, mas também da prisão.

Tomando o Massacre como o elemento inaugural das narrativas do cárcere, passo então a desenhar os temas trabalhados por estas duas narrativas, de modo a buscar compreender a maneira como o cárcere representa a si mesmo a partir da escrita e as formas a partir das quais busca extrapolar os muros e alcançar a sociedade mais ampla.

\footnotetext{
34 É somente quando Ramos encontra a liberdade, no ano de 2017 , que ele se dedica à elaboração de uma autobiografia, ainda não publicada.

35 O uso que Godói (2010) realiza do conceito de Foucault sobre a prisão enquanto um dispositivo carcerário para pensar a presença da prisão em bairros paulistanos e catalães pode ser útil para pensar essa presença da prisão nos textos de Ramos, tomando em conta que a diferença dos objetos de análise: o bairro, para Godói, e os livros do cárcere, para mim. Ainda que Ramos não faça uma referência direta à prisão, ela se revela como uma presença em todos seus textos, presença que também será estrutural para a narrativa de Mendes, analisada do capítulo subsequente.
} 


\subsubsection{Construção de trajetórias e subjetividades}

O relato de André du Rap descreve e esclarece um processo discutido pela bibliografia sobre as instituições "totais", nos termos de Goffman (2005). Uma vez no cárcere, indica o autor, o indivíduo recebe um número de prontuário, passando a ser identificado a partir da sua matrícula no sistema prisional, que os iguala aos demais a partir de alguns rituais de anulação do sujeito, como o corte dos cabelos, a obrigatoriedade do uso de uniformes e o utilização de números para identificação dos indivíduos, retirando-lhes o nome. Este número do prontuário irá acompanhar a vida do detento durante toda sua estada no cárcere, e, ainda, marcará suas relações quando ele se encontrar livre. No entanto, apesar dos rituais de anulação do sujeito marcarem efetivamente a entrada dos indivíduos no cárcere, sabemos que tal anulação jamais é completa, tendo em vista a maneira como os indivíduos experimentam esse processo, fornecendo resistência a ele.

André confirma que, uma vez preso, o sujeito carrega para sempre sua "carteirinha de bandido": ao entrar no sistema prisional, ele recebe um número, mas ao sair esse número continua de certa forma ligado a ele, em função da existência de registros criminais em sua Certidão de Antecedentes Criminais. Assim que, mesmo depois de "ter pago" à justiça pelo crime cometido (os anos passados na prisão), André afirma que continua pagando sua pena ao ser reconhecido como "bandido" por ter nos seus registros a referência a experiência carcerária. Quer dizer: a nova identidade do preso, forjada na sua entrada no sistema prisional, o acompanha mesmo na vida egressa.

Essa identidade, no entanto, não se parece com uma anulação do sujeito, ou com a construção de um outro (em tudo novo), reconhecido, a partir de então, como preso. Os indivíduos, uma vez no cárcere, negociam constantemente os processos de reconhecimento e construção de identidade, formulando para si e para os demais formas diversas de se compreenderem como pessoas. As narrativas do cárcere apontam caminhos para a compreensão das formas de agenciamento dos sujeitos acerca de suas identidades, revelando as disputas constantes envolvidas na constituição do sujeito preso. Uma das formas utilizadas para garantir o reconhecimento do sujeito apesar do cárcere (ou apesar da "carteira de bandido") é o uso de narrativas voltadas para as trajetórias na vida externa à prisão. O relato de trajetórias constitui o cerne de boa parte dos textos elaborados pelos presos, o que Câmara aponta como um esforço por parte dos seus autores de se reinserirem na sociedade 
que os segregou (CÂMARA, 2001, p.99) ${ }^{36}$. Assim que não soa estranho que André du Rap inicie seu relato - o que difere, como já dito, do início do livro - narrando os acontecimentos de sua vida no momento anterior ao cárcere, como fazem muitos outros, como Humberto Rodrigues e Luiz Alberto Mendes, autores que serão analisados no próximo capítulo. Ramos, apesar de não tratar de dimensões autobiográficas em Pavilhão 9, publica aí um conto em que narra a trajetória de um médico renomado que foi perseguido por criminosos e acusado injustamente, retomando nessa peça ficcional a sua trajetória precedente.

As trajetórias construídas e reconstruídas nos relatos referem-se em geral, como faz André du Rap, a sujeitos dotados de nome, inseridos em famílias, e que possuem algum tipo de ocupação: seja um emprego formal ou atividades que permitem alguma renda; quer dizer, os percursos são elaborados em função da composição de sujeitos anteriores ao cárcere, cujas vidas e experiências não se limitam a ela. André du Rap narra os fatos que o levaram a prisão, revelando as estratégias que realizou para escapar dela e defendendo ser sua condenação injusta. Apesar de seu livro não ser uma autobiografia - como é o caso de Mendes, que analisaremos adiante - sua trajetória anterior ao cárcere é elemento fundamental na construção de um sujeito diferente daquele que é reconhecido como "bandido", e isso mesmo depois de "ter pago" a sua pena e se encontrar em liberdade.

Este recurso à recuperação dos percursos e trajetos, presente em diversos escritos do cárcere, funciona sempre como um elemento de construção de uma identidade que não se limita à prisão. André du Rap, por exemplo, morava na Região Metropolitana de São Paulo, promovia bailes e eventos nas periferias, tinha desavenças na família, namorava uma menina que engravidou, mudou-se para Santos etc. Antes de receber o número de matrícula, portanto, possuía vida própria que ele retoma, por meio da narrativa e com a ajuda da qual ele reelabora a subjetividade ${ }^{37}$. Se os "rituais de anulação do sujeito", para utilizar os termos de Goffman, acontecem tanto no início da vida prisional quanto ao longo de toda a pena, as narrativas produzidas no cárcere podem ser percebidas como atos de resistência e negociação da elaboração de sujeitos, portadores de subjetividades e experiências específicas. Ao reafirmarem que possuíam uma vida fora do cárcere, não apenas apontam para acontecimentos de fora do presídio, vividos em momento anterior à prisão, mas afirmam, no

\footnotetext{
36 A autora aponta uma recorrência nos discursos prisionais, qual seja: a necessidade de narrar o passado, o que significaria a possibilidade de reconhecimento do sujeito para além do cárcere, assim como uma urgência que ele possui de voltar-se para o cotidiano, de forma a organizá-lo narrativamente, e auxiliando-o no cumprimento de sua pena.

${ }^{37}$ A construção do sujeito, por meio das narrativas do cárcere será o foco de análise do capítulo seguinte, em que analiso os volumes produzidos por Mendes e Rodrigues, voltados, quase inteiramente, para esse problema.
} 
presente do cárcere, que a identidade oferecida pela instituição para eles - portadores de um número de matrícula - não é suficiente e nem determinante e, portanto, não pode ser aceita como identidade única, unívoca. As narrativas do cárcere funcionam como forma de afirmar que a prisão, apesar de se tornar uma presença constante na vida destes autores, não é, nem pode ser, o único elemento a permitir uma compreensão do sujeito em situação de encarceramento.

\subsubsection{O cotidiano no cárcere: a solidariedade e a prática da escrita}

Narrar o cárcere é, quase sempre, dá-lo a conhecer àqueles que nunca entraram numa prisão, e isso sobretudo no caso dos relatos publicados na forma de livro. Rita Palmeira (2009) sugere que os autores da prisão buscam construir, a partir de um uso específico da linguagem, uma interlocução com um leitor que se encontra do lado de fora das grades. $\mathrm{O}$ principal artifício utilizado, diz ela, é a tentativa de explicar constantemente os termos oriundos desse universo: os autores mobilizam a linguagem do cárcere, realizando um trabalho de tradução para a linguagem corrente, ora utilizando os termos próprios do cárcere no corpo do texto, ora introduzindo notas explicativas ou glossários ao final. Estes e outros recursos, como também a utilização da narrativa do cotidiano, permitem reconhecer, segundo a autora, o leitor para o qual os autores do cárcere se dirigem, um leitor que se encontra fora do cárcere e o desconhece.

Além da tentativa de tradução linguística e de familiarização com um léxico próprio ao mundo das prisões, os autores procuram também descrever esse universo desconhecido para os que se encontram fora dele, relatando os percursos traçados em outras unidades prisionais até chegarem à Casa de Detenção. Isso porque, antes de chegarem ao Carandiru, muitos deles passaram por outras prisões, geralmente cadeias públicas, as antigas carceragens policiais, onde ficaram à espera do julgamento para que fossem encaminhados para algum presídio, no caso, a Casa de Detenção. Ao descreverem esses périplos até serem encaminhados ao Carandiru, eles frequentemente relatam o medo e a apreensão de terem que pagar suas penas naquilo que era conhecido como a "selva de pedra". No entanto, ao serem 
recebidos na nova instituição, o que marca as narrativas, de modo geral, é um encontro com uma ordem e solidariedade nunca vistas.

O espanto frente a um cotidiano organizado - apesar de opressor - é transmitido ao leitor, que pode, então, abandonar seus preconceitos em relação à vida no cárcere. Em outras palavras, é possível perceber um esforço de humanização do cárcere e dos próprios presos a partir da elaboração das narrativas: ao descreverem o cárcere como um lugar onde é possível viver e encontrar solidariedade e o cuidado dos companheiros, eles procuram mostrar como são pessoas capazes de se organizarem e viverem dignamente, mesmo que sob opressão institucional.

Dentro do sistema penitenciário existe muita solidariedade. Você pode chegar pelado, mas você não vai ficar pelado, um vai te dar uma camisa, outro vai te dar uma cueca, outro empresta um tênis. Quando a sua visita vier e trouxer roupa pra você, aí você devolve, retribui. [...] O que muitas vezes não existe aqui fora, existe lá dentro (DU RAP, ZENI, 2002, p.51).

Mas o digno de nota dessa tentativa de humanização do cárcere no caso de André du Rap, é que para ele a prática da escrita aparece como própria ao cotidiano prisional. Não apenas uma prática sua - André, mesmo antes de ser preso, compunha músicas e letras mas compartilhada entre os presos.

Quando você chega na cadeia, é uma expectativa pra quem já está lá dentro. 'Ô, chegou um mano da quebrada', e tal. O cara que está ali há dez anos sem ter notícia, naquele momento ele vai ter. 'Você viu o fulano lá? Não? E o mano lá, aquele que morava na rua de trás?', 'Pô, eu vi, ele está lá, está com saúde’. Você é tipo um mensageiro de uma notícia. Passa um mês, dois meses, chega um outro cara. Esse cara que chegou vai ser o seu mensageiro, vai trazer notícias pra você. Do mesmo jeito que você trouxe praqueles que estão ali, o próximo vem trazendo outras. Sempre que vai chegar um bonde de tal cadeia, 'Opa, vou lá pra ver se tem alguém da minha quebrada'. De repente, aparece lá um primo seu, um amigo seu de infância. 'Puta, meu, o que te levou?'. É uma forma de preencher o tempo - contar histórias. Dali, tudo é conteúdo pra você montar uma letra, um poema, uma poesia. Você fica com aquilo na mente. Por exemplo, o cara conta uma história duma mina que ele conheceu lá fora. Você coloca aquilo na mente e começa a escrever. Várias músicas minhas eu compus assim. História minha mesmo, uma mina que eu conheci aqui fora, uma mina que eu lembrava, uma situação que eu vi dentro do pavilhão. Então, tudo é conteúdo. É uma forma de você ocupar a mente. Lá dentro tem vários escritores, tem os caras que escrevem, pegam a caneta, montam 
várias histórias baseadas na sua história. A literatura é muito grande lá dentro, é infinita (DU RAP, ZENI, 2002, p.53 e 54).

O cotidiano prisional é, assim, matéria de escrita para André e seus companheiros. Falar sobre o cárcere é falar sobre as pessoas que chegam e sobre aquelas que vão embora; é falar sobre o que ficou lá fora e o que se trouxe para dentro; é lembrar os companheiros, falar das saudades. É falar, inclusive, sobre o que se fala, como faz André a partir de uma narrativa em que a oralidade é valorizada ao máximo, tendo as falas dos companheiros reproduzidas no texto escrito: “Você viu o fulano lá? Não? E o mano lá, aquele que morava na rua de trás?', 'Pô, eu vi, ele está lá, está com saúde”.'

A escrita aparece também como um modo de enfrentar o cotidiano prisional, que é permeado pelo tédio. Escrever seria uma forma de construir mundos, imaginar situações, lembrar:

O único conforto que eu tinha era a caneta e o papel. Escrevi muitos poemas nessas horas. Comecei a buscar outros meios de me expressar. Eu gostava muito de rap, comecei a compor. Eu já compunha antes, mas lá eu compunha mais. [...] Então eu fui pra Detenção, eu subia na minha jega e ficava lembrando daqueles tempos [quando estava livre e trabalhava com promoção de eventos]. Ficava compondo, escrevendo alguma coisa. Dali saía uma estrofe de uma música, um pedaço de um poema (DU RAP; ZENI, 2002, p.47 e 48).

Assim como os rituais de anulação do sujeito procuram delimitar o reconhecimento das subjetividades, o cotidiano definido pelas grades e muros do cárcere, em tudo igual e tedioso, constrói uma rotina em que o preso se vê duplamente aprisionado: nas celas e na vida diária. No entanto, da mesma forma como os presos resistem à anulação de si, eles também constroem, por meio da escrita, mundos outros que extrapolam os limites do cárcere, reorganizando-o, e a si próprios de forma inventiva.

\subsubsection{A violência}


Se a solidariedade e o cuidado com o companheiro são temas presentes na descrição do cotidiano prisional, o que aponta, mais uma vez, para uma humanização do cárcere, a presença da violência entre os presos, principalmente entre os agentes do estado e os presos, motivo mais recorrente nos textos de Hosmany Ramos e de vários outros, não pode ser negada. Para ele, narrar a prisão, ou a partir da prisão é, sempre, narrar a violência. Em seus textos, a violência é incorporada à linguagem, a narrativa parecendo a um estampido ou golpe $\operatorname{seco}^{38}$. Ao prefaciar o próprio livro, Ramos destaca o ponto:

A nota de relevo da história deste livro é a originalidade, a extravagância, a violência. A vivência prisional me deu oportunidade de conhecer de perto o sofrimento e o conflito entre os homens. Conhecer de perto pessoas que vivenciam a cada instante os limites da violência, da vida e da morte (RAMOS, 2001, p.11).

Mesmo que não escreva sobre si, é sua experiência como preso o que lhe permite trabalhar a narrativa a partir disto que ele chama de "originalidade" e "extravagância":

O que mais me leva a acreditar nesse livro como coisa viva reside no fato de que vi meus personagens de carne e osso. Convivi com condenados, assassinos e marginais; escutei suas histórias e observei o ponto de vista deles. Sentei no banco dos réus, pilotei uma cela e senti o cheiro insuportável da prisão, imaginando o quanto é fácil deixar de ser racional, para ser simplesmente um animal (RAMOS, 2001, p.12).

As narrativas deliberadamente ficcionais que ele constrói são elaboradas a partir da convivência com o cárcere, com suas agruras e, principalmente, com a violência. Os personagens compostos são aqueles que vivenciam a prisão, tanto dentro quanto fora do cárcere, transitando por espaços em que este se faz presente mesmo quando estão distante

\footnotetext{
${ }^{38}$ Talvez por isso Patrick Raynal, editor da Gallimard à época da publicação dos livros de Ramos na França, aponte uma "secura" nos textos do autor. "Secura' do texto atraiu editor francês", Folha de São Paulo, Ilustrada, 8/4/2000, disponível em: http://www1.folha.uol.com.br/fsp/ilustrad/fq0804200007.htm. Acesso em $8 / 1 / 2018$.
} 
dos muros e das grades ${ }^{39}$. Personagens que ao saírem da prisão, desumanizados, buscam vingança, elaboram teorias sobre o sistema de justiça criminal brasileiro; são assassinos em um momento e, no seguinte, assassinados; são traídos, encurralados e por vezes condenados injustamente. Ao privilegiar a violência como a enquadramento da narrativa prisional, Ramos desenha um quadro que, muitas vezes, foge às estruturas reconhecidas como típicas do cárcere, como veremos.

"Jogo de Xadrez" é o título do conto que abre o volume Pavilhão 9, e traz a história de um homem, de nome Legião, que foi preso e que, dentro da carceragem de uma polícia qualquer, desafia seus companheiros de cela a contarem seus feitos: aquele que narrasse a violência mais cruel ganharia um maço de cigarros. Os presos começam, então, a contar, principalmente, assaltos com torturas às vítimas. Mas Legião não se dá por satisfeito e afirma que ainda não ouviu uma história que realmente o convencesse da maldade do agressor. É quando um preso conhecido como Ceará inicia a sua história: um estupro de duas mulheres, uma delas grávida. Em seguida, Legião interfere no relato e fornece os detalhes daquele crime; Ceará se surpreende e questiona o homem, perguntando-lhe se é adivinho. Ao que ele responde negativamente, afirmando que as duas mulheres violentadas eram sua irmã e sua esposa. A partir da confissão inadvertida, Ceará é duramente violentado por Legião e, em seguida, por todos os presos daquela cela, finalmente assassinato, enforcado, mas tido como suicida.

Nas prisões brasileiras, os condenados por estupro são geralmente encaminhados para o "seguro", ou seja, para espaços separados da convivência prisional, já que correm o risco de serem mortos pelos demais ${ }^{40}$. No entanto, antes de serem encaminhados para as penitenciárias (ou seja, antes do julgamento e condenação), muitos dos acusados de estupro sofrem diversas violências nas carceragens policiais, tanto pelos próprios agentes do estado, quanto pelos companheiros de cela. Afinal, diz, Rodrigues, "Seja branco, negro ou pardo, velho ou moço, bom ou mau, ladrão ou assassino, não há preconceito algum. Exceto com os estupradores" (RODRIGUES, 2000, p.18). Pelo conto "Jogo de xadrez”, é possível afirmar que a violação sexual e a morte de Ceará após a sua confissão são plausíveis, no entanto, a sua confissão, no intuito de narrar o feito mais violento, parece deslocada quando se leva em

\footnotetext{
${ }^{39}$ Godói (2010) destaca ser a prisão uma presença forte em certos bairros periféricos de São Paulo, o que o leva a formular o conceito prisão-presença, aludindo à maneira como o cárcere está presente na vida de certas populações, ainda que elas possam jamais ter entrado num presídio.

40 Marques (2009) afirma aquilo que o "seguro", aquilo que a princípio é compreendido como um espaço separado da convivência prisional é, antes, um lugar simbólico de disputa pelo certo dentro de um contexto em que as ações de cada indivíduo são duramente vigiadas.
} 
conta a experiência prisional: se ele tivesse cometido o estupro sobre o qual constrói seu relato, e se ninguém ali soubesse do fato, ele jamais transformaria o evento em história narrada, conhecendo de antemão as regras que regem o convívio no cárcere e fora dele.

O conto não reflete mimeticamente, portanto, a vida prisional: não podemos interpretá-lo como um retrato daquilo que se dá no cárcere, como acabamos de dizer. Mas se, no entanto, ele for interpretado a partir de seu título, "Jogo de Xadrez", talvez seja possível encontrar outras saídas para a relação entre o narrado e o cotidiano na prisão. Legião, o homem que desafia os demais presos em busca do agressor de sua esposa e irmã, cometeu deliberadamente um crime de modo a ser preso e encaminhado para a mesma cadeia que seu inimigo. Ao chegar à cela, ele não tem conhecimento exato de quem é o indivíduo que procura; passa, então, a desafiar seus companheiros a narrarem os feitos mais cruéis, na certeza de que o culpado, na ânsia de contar o feito mais extraordinário, confessaria o estupro. Uma vez revelado o ocorrido, Legião teria legitimidade, frente a seus companheiros de cela, para não apenas matar seu alvo, mas antes, fazer com ele pior do que feito com sua família.

O ponto central do texto não é a ação (o estupro) nem a confissão de Ceará, mas antes, a estratégia de Legião. No entanto, a narrativa de Ceará é o que sobressai em uma primeira leitura, devido ao seu conteúdo altamente violento; narrativa que se constrói a partir de imagens realistas e chocantes, enquanto o narrador do texto, em terceira pessoa, descreve a agressão realizada contra o estuprador pelos demais personagens presentes na cena em questão.

São as atitudes de Legião o pivô do texto de Ramos, e estas se parecem a um jogo de xadrez, no qual os jogadores devem se antecipar aos movimentos do oponente, abrindo espaço para que este avance, atraindo-o para uma armadilha. Isso para dizer que a força do texto não reside na descrição da vida prisional tal e qual, mas na elaboração de uma estratégia, típica dos jogos de xadrez que, no ambiente prisional, tem a ver com uma ação que não mede esforços para alcançar seu objetivo de vingança. Não é à toa que este é o texto que abre o livro de Ramos; tampouco é gratuito que ele use a mesma expressão "jogo de xadrez" no prefácio do volume: "Grande parte destes contos são frutos da experiência e do 'jogo de xadrez', mais que da imaginação” (RAMOS, 2001, p.12). O que nos leva a crer que a escrita, para Ramos, é resultado de uma estratégia que planeja a ação tendo em vista a (re)ação esperada do seu oponente, fornecendo ao autor algumas ferramentas para lidar com o cotidiano prisional e os perigos e desafios do cárcere. 
A estratégia típica do "jogo de xadrez" mostra-se a chave também para a compreensão de outros textos do mesmo volume. O conto "Visita na cela" pode parecer, à primeira leitura, o relato de um caso de priapismo, ereção dolorosa e persistente, não acompanhada de desejo sexual, mas o enredo contraria a expectativa. O que diz o conto: Manuel encontra-se preso e Laura o visita na cela. Logo após as primeiras palavras, os dois têm uma relação sexual e Manuel, após um grito de dor, afirma que "aquilo aconteceu de novo", os seus corpos permanecendo encaixados. O conto, então, expõe as estratégias que os dois precisaram colocar em prática para até que a ereção de Manuel cedesse, Laura não fosse vista. Assim que, ao final do dia de visita, Manuel esconde Laura embaixo de um grande pano, e bate a porta no momento da movimentação dos visitantes, simulando sua saída. Com isso, os dois conseguem passar despercebidos pelos guardas e pelos demais presos por algum tempo, esperando o próximo final de semana para que ela pudesse sair. $\mathrm{O}$ problema se dá quando um companheiro de prisão passa pela cela e percebe que há uma outra pessoa ali. Quando a presença de Laura é descoberta, Manuel pede ao colega que guarde segredo. Mas pouco tempo depois todo o presídio já sabia do ocorrido, três guardas invadem a cela de Manuel e neste momento os dois, no susto, se "desencaixam"; Manuel é agredido no pênis com um cassetete, e aos pontapés é levado para a solitária. Quando voltaram para cela, onde Laura estava sozinha, ela é violentada cruelmente.

Sabemos que no Sistema Penitenciário Brasileiro, as celas individuais existem em casos absolutamente excepcionais; o Regime Disciplinas Diferenciado (RDD) é o único que determina a prisão em celas individuais. Para indivíduos com nível superior, estas só são garantidas quando os suspeitos estão presos em cadeias ou carceragens policiais. Depois do julgamento, momento em que o condenado é encaminhado a uma penitenciária para cumprir a sua pena, as celas são sempre compartilhadas. Há relatos de celas individuais em alguns presídios, no entanto, frente ao cenário de superlotação, jamais uma cela individual é a regra nos presídios brasileiros. O que nos leva a questionar a possibilidade de Manuel viver numa cela individual e receber ali a visita de Laura. Se a maneira como a visita foi realizada no conto pode parecer incompatível com a realidade do cotidiano prisional, a violência sofrida pelos personagens, por sua vez, é bastante plausível:

Os guardas voltaram com os rostos cobertos por máscaras. Estavam munidos de esparadrapos e algodão. Encheram a boca dela de algodão e fecharam com o esparadrapo. Um deles falou obscenidades e disse:

- Tá pensando que isto aqui é bordel? 
Outro tirou do bolso pó de pimenta malagueta e colocou num êmbolo semelhante a uma seringa. Um terceiro jogou ela no chão, sentou sobre sua barriga e abriu-lhe as pernas. Aplicou o êmbolo de pimenta dentro da vagina intumescida. Ela começou a debater-se de dor, como uma ave degolada. O terceiro homem aproximou-se dela com ar de deboche e disse:

- Fica quieta, sua vaca. Conheço uma puta lá na zona que gostaria de estar no seu lugar.

Um outro olhou para ela e disse:

-Se você contar para a diretoria, a gente estoura seu marido que está a cela forte. Sabia que é comum os presos se matarem na prisão?

Depois que tudo acabou, ela ficou deitada no chão, divagando (RAMOS, 2001, p.44-45).

Este conto pode ser analisado, mais uma vez, a partir das estratégias utilizadas num jogo de xadrez, como afirma o próprio autor. Aqui, diferente do conto anterior (em que a ação dos personagens se assemelham a de estrategistas), o próprio texto deve ser lido como esta ação estratégica do autor voltada para a narrativa do cotidiano prisional e denúncia de sua violência. Num primeiro momento, Ramos descreve a prisão a partir de artifícios que não condizem com a realidade do sistema prisional brasileiro (celas individuais) para em seguida narrar a tortura policial, que, de tão brutal, soa como um artifício para chocar o leitor, fazendo-o crer, talvez, que é a violência o que não condiz com a realidade. A partir de uma estratégia narrativa, o autor nos leva a questionar a veracidade de sua própria descrição, para então dar o xeque-mate: a violência brutal sofrida pelos presos e seus parentes no cárcere brasileiro, de tão hiperbólica, parece uma ficção para aqueles que estão longe dos muros e das grades.

Esta descrição hiperbólica da violência também aparece no conto Samurai do asfalto, no qual Ramos constrói a trajetória de Roque, um jovem preso injustamente e, aos poucos, abandonado pela família e também pelo advogado que o defendia, visto que perdeu todo seu dinheiro na tentativa de se livrar da condenação. Depois de cumprida a pena (integralmente em regime fechado), ele é libertado no meio da noite e vai à procura daqueles que julgava serem responsáveis pela sua prisão. Em primeiro lugar, se dirige ao escritório do advogado e o assassina. Em seguida, segue até a casa do promotor de seu caso e o executa. Por fim, vai em busca do delegado responsável pela sua prisão, que também é morto por ele. O texto é uma sequência de assassinatos brutais cometidos por Roque como vingança pela sua prisão. O assassino, apesar de ter desejado de antemão a morte de seus desafetos, não planeja as 
mortes: ele sai da prisão e simplesmente se dirige a cada um deles na intenção de matá-los sem, no entanto, planejar a forma como executará o seu plano. O texto assume ritmo veloz já que o narrador segue apenas as ações de Roque, não se ocupando de descrições do ambiente, tampouco detendo-se nos pensamentos do personagem. Ele age, e o narrador apenas acompanha sua ação.

Ao optar por essa forma narrativa centrada na ação, Ramos faz sobressair a irracionalidade da violência. Roque não pensa para agir, ele se parece com uma máquina de matar. No entanto, essa irracionalidade não é gratuita, já que foi construída ao longo dos anos no cumprimento da condenação de Roque. A violência, portanto, é resultado não da irracionalidade humana, mas antes, da irracionalidade da própria prisão: Roque foi fabricado por essa prisão, tornando-se uma pessoa capaz de matar sem expressar sentimentos ou razão. A crítica de Ramos ao sistema de justiça criminal e ao sistema prisional, neste texto, não é direta, o que acontece em outros contos do livro. O que torna o texto mais interessante do que uma simples descrição da experiência prisional. Ramos mostra o que a prisão produz seus efeitos nefastos a partir de personagens que são, de certo modo, a corporificação da irracionalidade do sistema. Se Roque pode ser interpretado como uma máquina de matar, despido de qualquer humanidade, o próprio sistema prisional brasileiro deve ser compreendido da mesma maneira, e se aceitamos a violência deste sistema, resta-nos aceitar, também, a crueza da violência de Roque.

Em Pavilhão 9, Ramos trabalha o tema da violência prisional de forma bastante diversa daquela que percebemos em outros livros do cárcere, incluindo aqueles que compõem o corpus desta pesquisa. André du Rap, ao descrever os horrores do Massacre do Carandiru, utiliza-se de uma linguagem fragmentada, em que os eventos são encadeados de forma truncada e nos quais o narrador, na impossibilidade de recordar a experiência e de descrevê-la como vivida, recorre ao artifício do uso do "você", numa alusão ao interlocutor, para falar da violência ${ }^{41}$. A narrativa de André aproxima-se assim da chamada literatura de testemunho, e é por meio dela que dá conta de falar sobre a violência ${ }^{42}$.

\footnotetext{
41 "Você imagine mais de dois mil companheiros presos em situação de pânico. Tentando se defender, escapar da morte. Você escuta um tiro, o sentimento é de pânico” (DU RAP, ZENI, 2002, p.19).

42 É mais uma vez Palmeira (2009, p.75) que nos ajuda a compreender o relato ao afirmar que essa aproximação ao interlocutor a partir do uso do "você" ("você imagine") pode ser percebida tanto como uma forma de fazer o leitor se colocar na situação vivenciada, de forma a generalizar a sua própria experiência, como também o resultado de uma incapacidade de voltar à própria experiência a partir da narrativa em primeira pessoa. Essa seria uma característica dos testemunhos em geral, categoria na qual se insere a narrativa de André.
} 
Ramos, por sua vez, afasta-se do testemunho e enfrenta o tema da violência por meio da ficcionalização. Se a violência extrema emudece, anulando a capacidade de fala, Ramos dá vida a personagens que vivenciam essa violência, seja na forma de vítimas ou, também, de agressores. Nesse sentido, o texto de Ramos abre espaço para que a violência seja enunciada e, para que isso se dê, ele se afasta da experiência (o que nos levaria para a esfera do testemunho) e aproxima-se da ficção. O distanciamento da experiência permite uma compreensão nova do mesmo fenômeno, ou seja, permite-nos aproximar da experiência da violência por meio de uma narrativa diversa.

De formas distintas, os livros de André du Rap e Hosmany Ramos constroem uma compreensão sobre o cárcere, ancorada na memória da experiência vivida, na qual a violência é essencial e se reveste de distintas formas. A escrita, ligada intimamente à vida nas prisões, é uma prática de resistência a ela, fazendo com os presos recomponham-se como sujeitos e subjetividades. A publicação dos relatos, por sua vez, projeta suas experiências e seus autores para fora. Ao alcançarem um público que se encontra do lado de fora da prisão, elas contribuem para dar existência social, e notoriedade, a esses sujeitos, além de produzirem um imaginário mais amplo sobre o cárcere. Trilhar os caminhos narrativos de André e Hosmany é também buscar uma compreensão sobre os fluxos entre o dentro e o fora do cárcere, já que aquilo que se produz na prisão (um entendimento sobre a prisão e a experiência prisional) alcança uma população que desconhece a vida prisional, ao mesmo tempo em que essa produção narrativa deve ser compreendida como o resultado de um interesse pelo cárcere que nasce na sociedade após o Massacre do Carandiru.

Além disso, como relatos que retiram sua força da experiência e da memória, eles funcionam, eles próprios, como elementos disparadores de memória; memória de si e, sobretudo, do evento trágico que conheceram, o Massacre do Carandiru. 


\section{CAPÍTULO 2}

\section{A PRÁTICA DA ESCRITA NO CÁRCERE E A PRODUÇÃO DE SUJEITOS HUMANOS}

A literatura é muito grande lá dentro, é infinita.

André du Rap

Autor da epígrafe acima, André du Rap produziu um livro tendo como base sua experiência no cárcere e, nesta obra, tematizou a escrita na prisão. Ao lado dele, é possível localizar outros autores que fazem o mesmo, partindo de dicções diversas. É o caso de Luiz Alberto Mendes e Humberto Rodrigues cujas obras - que serão analisadas neste capítulo permitem uma compreensão sobre os desafios da escrita no cárcere e também lançam luz sobre as modalidades de textos oriundos de um ambiente pautado por privações de vários tipos.

Apesar de condições à primeira vista adversas à prática da escrita (falta de privacidade e de meios materiais adequados, além de difícil acesso a livros e jornais), o cárcere é um universo profícuo para o desenvolvimento de diversos tipos de textos. Escritos do (e no) cárcere povoam o cânone literário, indicam, entre muitos outros exemplos, Recordação da casa dos mortos, de Dostoiévski, (1861) e Memórias do cárcere de Graciliano Ramos (1953). Sabemos também como a escrita epistolar, desde o cárcere, deu origens a publicações que tornaram públicas as torturas e abusos, indicam exemplos como os de Frei Betto e suas Cartas da Prisão (1997).

Os exemplos indicados são diferentes, em diversos sentidos, dos livros produzidos por presos depois do Massacre do Carandiru. Os autores que surgiram sobretudo após este 
evento não eram intelectuais, mas presos comuns que se tornaram, alguns deles, escritores na prisão. Essa nova literatura do cárcere é produzida a partir de um contexto prisional marcado pela baixa escolaridade dos $\operatorname{presos}^{43}$, reflexo da escolaridade precária da população que sofre encarceramento no Brasil - na sua maioria jovens, negros e de baixa renda ${ }^{44}$.

A baixa escolaridade, no entanto, não está ligada, como poderia parecer ao olhar desinteressado, a uma ausência da prática da escrita. A escrita, como sugere Goody (2012) refletindo sobre outro contexto, é utilizada, geralmente, como um marcador de diferenças: os povos "civilizados" fariam uso da escrita, se reconhecendo a partir dela, enquanto os "não civilizados" - "primitivos", "arcaicos" - apesar de utilizarem, por vezes, a escrita, não se reconheceriam a partir dela. Antes de ser um marco que diferencia sociedades distintas, a escrita seria utilizada, segundo esse autor, como um instrumento de diferenciação e hierarquização: somos nós, aqueles que utilizamos a escrita e nos reconhecemos a partir dela, quem dizemos que o outro não a utiliza. Ainda que parta da dicotomia, Goody chama a atenção para a sua fragilidade: mesmo nas sociedades letradas, a oralidade marca a grande maioria das relações, dos contratos, dos rituais e construções simbólicas; nas sociedades reconhecidamente orais, por sua vez, a escrita possui um papel importante em determinadas situações, como a contagem, a numeração etc.

Essa dicotomia - entre nós que utilizamos a escrita e eles que não se reconhecem a partir dela - parece sugestiva para que compreendamos a maneira como a prisão é percebida pela sociedade mais ampla já que seu domínio é utilizado, ensina Goody (2012) como marco de diferenciação. Rita Palmeira (2009) identifica um esforço dos autores presos de se colocarem ao lado dos "homens livres" por meio da produção de livros. Segundo a autora, pelo manejo da escrita, da elaboração e publicação de livros os "homens do crime", constroem um sujeito "escritor", fazendo enorme esforço para se distanciarem dessa categoria, e para se aproximarem da outra (“homens livres”).

\footnotetext{
43 O relatório produzido pelo DEPEN sobre o perfil da população prisional, referente a dados coletados em 2014, informa que, naquele ano, $75 \%$ da população prisional era formada por indivíduos com até o fundamental completo, o que significa que essa parcela era analfabeta, alfabetizada informalmente ou completou apenas o ensino fundamental e cessou os estudos. A outra parcela, 25\%, era formada por indivíduos que possuíam desde o ensino médio incompleto até o ensino superior completo.

44 O relatório do Depen (2014) também traz dados sobre raça e faixa etária dos presos, indicando que, para o ano de 2014, a população prisional era formada por 61,67\% de negros, pretos e pardos, e que os jovens entre 18 e 29 anos formam 55\% desta população. Uma comparação entre o perfil da população prisional e a população brasileira aponta algumas discrepâncias, o que indica uma representatividade maior de negros e jovens no sistema prisional se comparado com o total da população do país: enquanto na população brasileira negros, pretos e pardos representam 53,7\%, nos presídios essa parcela alcança a marca dos $61,7 \%$, em relação aos jovens, no país eles representam 18,9\%, enquanto na prisão são $55 \%$.
} 
Se a dicotomia entre um nós ("homens livres") que escreve e um eles ("homens do crime") pouco afeitos à escrita é frequentemente acionada, habitando certo imaginário, um olhar atento à realidade prisional revela um cenário diverso: a prática da escrita é bastante presente no cárcere. Os presos escrevem continuamente: cartas, poemas, letras de música, diários, memórias, autobiografias, documentos, tatuagens e também livros. Nem todos o fazem com a mesma facilidade, é verdade: aqueles que dominam a escrita muitas vezes escrevem para os outros, como aponta André Du Rap (2002) ao mencionar como escreveu cartas e poemas para os familiares de outros presos, além das cartas, poemas, letras de música que escrevia para si próprio. Assim afirmar que escrita é própria ao universo prisional nos afasta de uma diferenciação rígida entre a sociedade mais ampla e o cárcere a partir da prática da escrita, indicando também como ela atua como um marcador de diferenças dentro do próprio cárcere. Como veremos a partir da produção de dois autores específicos - Mendes e Rodrigues - a escrita cria diferenças e produz sujeitos em um universo marcado pela anulação da identidade anterior à experiência de encarceramento.

No cárcere são escritos cartas, livros, papéis escritos, documentos etc.; todos estes artefatos que geram efeitos muito diversos; por meio deles são produzidos diferenças, sujeitos, histórias, memórias, imaginários, identidades. São os efeitos da escrita no cárcere o que me interessa compreender nesse capítulo, tentando identificar aquilo que a escrita produz, também a maneira como ela circula no cárcere e o modo como faz circular o próprio cárcere. Ainda que o problema possa ser enfrentado com auxílio de casos variados, pretendo examiná-lo à luz de dois exemplos. No início da década de 2000, dois volumes foram produzidos e publicados por presos do Carandiru: Memórias de um sobrevivente, de Luiz Alberto Mendes (1952-), e Vidas do Carandiru, de Humberto Rodrigues (1933-). Dentre outros volumes similares publicados na mesma década, os livros de Rodrigues e de Mendes oferecem um material rico para a análise por trazerem, na própria narrativa - e também como seu efeito - a construção de um sujeito diferente dos demais presos, e também distinto daquele que é identificado como o preso pela sociedade extramuros - elaborando aquilo que chamarei de sujeito bumano.

A maneira como a sociedade extramuros, de modo geral, constrói um entendimento sobre a população prisional pode ser compreendida a partir de uma política de diferenciação. Butler (2015) ensina que nem todas as vidas humanas são reconhecidas como vidas, e por isso há aquelas sobre as quais se deve chorar a morte (vidas que importam) e outras que não contam como vidas, não são passíveis de luto. Essa "política do luto", segundo a qual 
somente algumas mortes são lamentadas, sugere Butler, é o resultado de um processo de "enquadramento", ao qual os indivíduos de uma sociedade, a partir de uma educação dos afetos - e, portanto, a partir de uma política da interpretação - aprendem a reconhecer a existência humana de forma seletiva ${ }^{45}$.

A frase "bandido bom é bandido morto", recorrentemente utilizada por aqueles que se opõem, de alguma forma, à discussão e à efetivação dos Direitos Humanos dos presos, é reveladora do enquadramento a que Butler alude para pensar as vidas que são contadas como vidas humanas e as demais, pensadas apenas como seres vivos ${ }^{46}$. O direito à vida, neste caso, não alcançaria os "bandidos", o que garante não apenas que suas mortes não devem ser choradas, mas, o que é pior, deveriam ser desejadas. Quando Nuno Ramos reencena a leitura dos nomes dos 111 presos mortos no Massacre do Carandiru, referida antes, o que está em jogo é justamente esse "enquadramento" relacionado à condição de vida que não é contada como vida, mas apenas como ser vivo. Ler e reler os nomes dos mortos é uma forma de construir um luto que foi negado a essas pessoas que, por não contarem como vidas humanas, não puderam ter suas mortes choradas e lamentadas no espaço público; lembrar tais mortes auxilia, inclusive, a modificar as políticas da memória e a reformular o enquadramento que garante um "reconhecimento" aos presos.

Os volumes publicados por Mendes e Rodrigues interpelam essa "política de enquadramento": através da leitura destes livros nota-se um esforço dos autores (na prisão) para modificarem essa compreensão seletiva da vida humana que afeta o "reconhecimento" dos presos. A produção de narrativas no cárcere assume, desse ponto de vista, um caráter moral em que a interpretação construída sobre a pessoa presa é questionada e pode, assim, ser modificada, como veremos ao longo deste capítulo.

O esforço de ampliação do "enquadramento" que determina a condição de humano ao sujeito preso se dá a partir da construção de narrativas. Tais narrativas pautam-se na elaboração da memória, no uso e controle do tempo a partir da prática da escrita (e elaboração de diários), na construção de uma consciência sobre si e sobre a história do país, na formulação de afetos e da imagem pessoal, entre outros elementos presentes na

\footnotetext{
${ }^{45}$ Uso aqui o termo enquadramento como uma janela ou quadro que determina os limites da percepção ou do conhecimento, me apropriando do conceito de enquadramento de Butler. No entanto, utilizo-o não apenas como condição de compreensão sobre o outro, levando em conta a percepção de humanidade, mas para pensar também a experiência do indivíduo a partir das suas possibilidades de compreensão.

${ }^{46}$ Nas palavras da autora: "Essas populações [populações-alvo] são 'perdíveis', ou podem ser sacrificadas, precisamente porque foram enquadradas como já tendo sido perdidas ou sacrificadas, são consideradas como ameaças à vida humana tal como a conhecemos, e não como populações vivas que necessitam de proteção contra a violência ilegítima do Estado, a fome e a pandemias" (BUTLER, 2015, p.53).
} 
composição das narrativas dos autores. A prática da escrita no cárcere não foge aos cânones da chamada "escrita de si", da qual fazem parte as memórias, biografias, autobiografias e cartas. No entanto, ao forjarem, por meio da escrita, um "eu" negado em sua subjetividade, tais narrativas inauguram uma maneira nova de perceber a construção do sujeito preso, e mais ainda, fazem circular essa noção, o que força uma mudança no "enquadramento" em relação a esse sujeito.

Para melhor desenvolvimento da análise das narrativas de Mendes e Rodrigues, optei por focalizar cada uma delas separadamente, para colorir aquilo que cada uma delas traz de potencial para a compreensão da função da escrita no cárcere, buscando, posteriormente, apontar as proximidades e os distanciamentos entre elas.

\subsection{LUIZ ALBERTO MENDES: A CONSTRUÇÃO DO SUJEITO AUTOR A PARTIR DA AUTOBIOGRAFIA DE UM PRESO}

Memórias de um sobrevivente foi publicado pela Companhia das Letras, em 2001, quando Luiz Alberto Mendes se encontrava preso. Ainda no cárcere, ele publicaria outros livros, tornando-se inclusive colunista da Revista TRIP $^{47}$ a partir de 2001, mesmo ano em que publica suas memórias. Quando ganha a liberdade, Mendes continua a carreira de escritor, publicando, até o momento, seis livros. O seu volume de estreia, Memórias de um sobrevivente, foi adaptado para o teatro por Teco Tavares em 2012, com o título, O Sobrevivente, ainda não encenada (o projeto aguarda financiamento para a sua estreia).

Mendes foi “descoberto" pelo jornalista e escritor Fernando Bonassi em 1999, quando, ao lado de Sophia Bisilliat ${ }^{48}$, idealizam oficinas literárias no Carandiru, visando a realização de um concurso. É nesse momento que ele é premiado com o conto Cela Forte, título que foi transformado em livro no ano de 2012, pela Global Editora. À época das oficinas literárias, quando já cumpria mais de vinte anos de prisão, Mendes entregaria a Bonassi um calhamaço de folhas que já continha o texto integral de Memórias de um

${ }^{47}$ A TRIP é uma revista brasileira, criada em 1986, de publicação mensal e veiculação impressa nacional, voltada para a publicação de matérias jornalísticas e colunas assinadas por colaboradores vinculados ao meio artístico. ${ }^{48}$ Sophia Bisilliat, 56, é atriz e modelo, filha da fotógrafa inglesa Maurren Bisilliat, realizou trabalho voluntário por quase vinte anos no Carandiru, sendo o teatro seu principal foco de atuação entre os detentos. 
Sobrevivente, escrito dez anos antes. Ao tomar conhecimento daqueles escritos, Bonassi incentivou-o a empreender uma revisão do texto, comprometendo-se a auxiliá-lo na publicação do livro.

A publicação do livro se dá, então, em 2001, pela editora paulistana, que publicaria, posteriormente, Às cegas (2005) e Confissões de um homem livre (2015) - os três livros formando a trilogia definida como a autobiografia de $\mathrm{Mendes}^{49}$. Uma vez em liberdade, após cumprir quase 32 anos de prisão, Mendes passa a se dedicar à literatura, tanto pela produção literária, quanto pela realização de oficinais literárias em diversas unidades prisionais do Brasil.

Em Memórias de um sobrevivente o autor revê suas memórias, no momento em que se encontrava preso, há pelo menos dez anos. A leitura e a escrita fazem parte da experiência prisional e por isso mesmo são tematizadas. Nos primeiros tempos de prisão, Mendes trava conhecimento com um colega de cela que o incentiva à leitura. Praticamente analfabeto, como ele próprio afirma, passa, então, a se dedicar aos livros como a principal maneira de lidar com o cotidiano prisional. É por meio da leitura que dá início a uma transformação de valores que, nas suas palavras, deixam de ser pautados pelos "códigos do crime" e passam, então, a ser formulados com o auxílio de obras clássicas da literatura e da filosofia. Imbuído desses "novos valores", inicia a composição de sua autobiografia, narrando sua trajetória a partir de um ponto de vista que se não valoriza as conquistas do universo do crime, tampouco se inocenta diante dos feitos pretéritos. Após narrar sua trajetória até chegar ao Carandiru, detendo-se, sobretudo, sobre os primeiros anos de prisão, o autor, no final do volume, discorre sobre a elaboração do texto: como se deu a sua aproximação com o universo da leitura e da escrita; como conheceu o jornalista Fernando Bonassi, responsável pela revisão do texto para publicação.

É no epílogo que compreendemos as razões que levaram Mendes a escrever a sua autobiografia (já que não há um prefácio do autor, somente uma breve apresentação de Bonassi). Aí, ele indica que sua história não compreende nenhuma lição ou ensinamento a ser transmitido, mas foi elaborada apenas como uma forma de buscar compreender sua trajetória, marcada pelo fato de continuar preso, “como sempre” (MENDES, 2001, p.414).

\footnotetext{
49 Apesar dos três volumes formarem a autobiografia de Mendes, é o primeiro volume que me interessa, já que este foi escrito e publicado enquanto ele ainda se encontrava preso, os demais publicados quando o autor já se encontrava em liberdade. O primeiro volume da trilogia, objeto de análise desta pesquisa, é voltado para a trajetória de Mendes desde a infância até os dez primeiros anos em que esteve preso, o que dá conta da transformação de seus valores e comportamentos a partir da prática da leitura e escrita. Os demais volumes, apesar de ainda tomarem como objeto a vida prisional de Mendes, são pautados nas experiências vividas pelo autor quando ele se encontrava em regime semiaberto e que, por vezes, teve que voltar à prisão por crimes cometidos nesses períodos.
} 
Em suas palavras: "não estou aqui para filosofar. Sou de opinião que os fatos, a vida, falam por si mesmos e não carecem de explicações, e sim, e tão somente, de narração acurada. As conclusões e ilações, sem dúvida, são pessoais” (MENDES, 2001, p.410).

Apesar de valorizar a narrativa como suficiente para a compreensão de seu percurso, o autor confessa que nem sempre foi fácil fazê-la:

Nos últimos quatro meses, revivi este livro todinho, página por página, palavra por palavra. Foi uma viagem muito difícil. Houve momento em que pareceu que tudo estava acontecendo de novo. Particularmente, nos instantes de maior sofrimento. Doeu, doeu fundo, mas eu precisava mergulhar naquilo de novo (MENDES, 2001, p.413).

Ao reviver sua história, narrando diversos episódios em que foi torturado por policiais ou por colegas de cela, Mendes afirma constantemente a presença da dor, e depois de quase trinta anos de prisão, sugere uma maneira possível de lidar com ela:

A dor submete. A dor humilha até nos fazer qual pó de estrada, tapete do mundo. Dizem que ensina. Sem dúvida, ensina. Principalmente a não querê-la mais, de modo nenhum, por mais que contenha qualquer ensinamento. Mas, quem somos nós, né, míseros mortais, para querer ou não? (MENDES, 2001, p.413).

Narrar, portanto, é reviver: a escrita figurando como uma forma de experiência. Além disso, Mendes afirma que esta lhe serviu como forma de ter o controle de sua existência não dos fatos, que parecem lhe escapar, mas de sua compreensão:

A intenção do livro não foi a de ter uma mensagem. Não tenho essa pretensão. Apenas escrevi para ter uma sequência que permitisse que eu mesmo entendesse o que havia acontecido realmente. [...] Eu queria ordenar momentos em acontecimentos, ações e reações, para ver se entendia um pouco dessa balbúrdia que foi minha existência (MENDES, 2001, p.415).

Se a narrativa garante a Mendes a possibilidade de ordenamento dos momentos vividos e de compreensão de sua vida, a própria escrita é o que modifica a sua trajetória e 
informa uma nova maneira de lidar com o cotidiano prisional, pautado em valores outros que não aqueles que determinam os "códigos do crime". Essa mudança nos valores a partir da prática da escrita poderia parecer, à primeira vista, um processo de ressocialização do preso, no qual ele reconhece os valores de uma sociedade que lhe seria estranha, e aos quais deveria aderir. No entanto, não é para essa sociedade que ele se volta quando vê seus valores transformados. Seu mundo é o da prisão, "como sempre" (MENDES, 2001, p.409). Por mais que seus escritos alcancem o que se encontra do outro lado das grades, é dentro da prisão que ele se percebe modificado pela escrita; é ali que continua vivendo e sobrevivendo com seus novos valores e nova forma de ver o mundo. A escrita não salvou Mendes do crime, antes, o ajudou a sobreviver ao cotidiano e a vida prisional.

\subsubsection{Prisão e violência: forma, conteúdo e princípio de entendimento}

Na escrita do cárcere, a prisão, não é apenas um lugar de enunciação, mas também a condição e possibilidade de escrita: ela determina tanto a forma que o texto irá assumir, como o seu enunciado. Em Mendes, assim como em todos os outros autores do cárcere analisados, a prisão não se apresenta apenas como fornecendo o conteúdo da escrita do cárcere (autores da prisão falam, na grande maioria dos textos, sobre a própria prisão), mas dá forma ao texto e à interpretação do mundo. A prática da escrita não modifica, no preso, o "enquadramento" oferecido pela prisão, ao contrário, é por meio dele que o autor escreve sobre sua infância, memórias, afetos etc. Mas para além de funcionar como um marco de entendimento da experiência individual e do mundo, a prisão é também condição material que determina o artefato - texto escrito - que será produzido, como veremos.

Ao escrever a sua história, Mendes lança mão de uma das convenções da autobiografia que é dar início à narrativa pela descrição da infância. No começo, ele volta-se para as ruas da Vila Maria, bairro da zona norte de São Paulo, na década de 1970, quando, então menino, esquivava-se como podia da violência do pai, ao mesmo tempo em que fugia da escola e, junto com a molecada do bairro, vivia pelas ruas a pensar em formas de conseguir algum dinheiro para comprar doces. Já se nota ali problemas familiares a partir da presença de um pai alcoólatra e violento, ao mesmo tempo em que transparece a pobreza na 
qual estava inserida a família; o pai constantemente desempregado e a mãe que se esforçava para costurar para fora e ganhar algum dinheiro para sustentar a família de forma humilde, contando com a ajuda de parentes que se encontravam numa situação um pouco mais confortável economicamente.

O que permeia a narrativa da infância de Mendes são três temas em especial: a violência paterna em relação a ele, a pobreza e a convivência com os garotos do bairro vivência que trazia indícios de uma aproximação futura com a criminalidade $e^{50}$. A prisão, apesar de não fazer parte da experiência de Mendes na infância - não há, por exemplo, relato de pessoas presas próximas a Mendes, nem narrativas de experiências de outros em relação à prisão - está presente como "enquadramento".

Já no início do livro, ao descrever a casa onde morava com os pais, ele relata:

Não suportava a reduzida prisão que se tornara minha casa. O quintal era pouco maior que a cela de uma cadeia. Tudo ali era velho demais para mim, já tinha visto aquilo tudo milhões de vezes. O assoalho que eu encerava desde pequenino, o telhado cheio de goteiras, os ratos do porão, tudo ali me cansava.

[...] Para mim a escola sabia a prisão. O prédio do Grupo Escolar João Vieira de Almeida, esse ilustre desconhecido, parecia com prisão: possuía grades e tudo o mais (MENDES, 2001, p.11/21).

Se, por um lado, os pontos negativos de sua infância "sabiam a prisão" - a casa, os deveres, a escola - os pontos positivos voltavam-se para algo que também "sabe" a prisão: a liberdade.

Correndo, rindo, fazendo festa, atrapalhando os transeuntes como se as ruas fossem nossas, subimos as escadas rolantes da Galeria Metrópole. No terceiro piso, Saci levou-me a um bar que era meio lanchonete, meio boate, muito moderno na época, com uma vitrola de colocar fichas. Nunca tinha visto lugar tão lindo. O Snake era realmente lindo, faiscante de luzes e cores, subiu uma onda de prazer que me arrepiava todo! Estava lotado de jovens. Tocava rock dos Rolling Stones, "Satisfation" numa altura alucinante. Eu vibrava, respirava fundo. Sim, era realmente aquilo que eu queria, aquele lugar! Era isso, seria feliz, finalmente. Sugaria até a última

\footnotetext{
${ }^{50}$ Mendes não generaliza as relações entre pobreza e criminalidade; é quando busca explicações para certas ações passadas que faz relações entre a sua situação de pobreza e os primeiros atos ilícitos, cometidos no intuito de conseguir dinheiro para suprir suas necessidades de menino, algo que sua família não poderia fazer.
} 
gota de toda aquela liberdade, de toda aquela satisfação. Ninguém me impediria. Acho que foi a primeira vez que me senti realmente livre (MENDES, 2001, p. 40-41).

Mendes descreve o clima social no qual viviam os jovens na década de 1970, estes que frequentavam o Snake, na Galeria Metrópole, no centro de São Paulo, meninos e meninas que, como ele, haviam se distanciado de casa e vibravam com um clima onde imperavam outras regras que não aquelas impostas pelos pais ou pelo trabalho:

$\mathrm{Na}$ família, a vida da maioria era de razoável para boa, em termos de conforto e comodidade. Principalmente a das garotas, quase todas de origem burguesa. Mas havia um fascínio pela liberdade que vinham vivendo junto de pessoas que, como eles, não aguentavam mais o esquema familiar. Nem a escola, com seus regulamentos, proibições e limites impostos. [...] Seguíamos movidos por uma vontade mais poderosa do que aquilo que os nossos pais nos impunham. Na verdade, o sonho de ser livre começara. (MENDES, 2001, p.43, grifo nosso).

Éramos crianças e tudo era brinquedo, alegria e farra para nós. Em São Paulo, naquele tempo, havia pouquíssimos roubos. Era tempo de amarrar o cachorro com linguiça, como se dizia. As pessoas deixavam suas casas, tranquilamente, sem ninguém vigiando. Juntei-me a eles. Éramos vândalos e da pior espécie, aquela que destrói pelo prazer de destruir. [...] Adorava aquilo! Parecia haver encontrado minha família, e aquela era minha diversão favorita. Colocava toda a minha raiva, meu ódio naquela atividade destruidora. Estava ficando louco de liberdade. Um selvagenzinho alucinado. (MENDES, 2001, p.48-49, grifo nosso).

A prisão, associada às regras, à escola e à família, e o seu oposto, a liberdade, organizam a narrativa; prisão e liberdade não são apenas temas de Mendes, mas polos estruturantes mobilizados para a compreensão da experiência vivida do autor, o que nos leva para o lugar de enunciação de Mendes: ele escreve do interior da prisão e é esta a lente utilizada para compreender sua trajetória. $\mathrm{Na}$ escrita de Mendes, ora a prisão apresenta-se como forma, ora conteúdo, mas fornece, sobretudo, limites de compreensão do mundo e de sua enunciação.

Se a prisão oferece o "enquadramento" que permite o desenvolvimento da escrita do cárcere de Mendes, a violência, por sua vez, aparece como elemento obrigatório e tema recorrente. É ainda Butler (2015) que ensina ser a condição de precariedade que marca a condição humana; afinal, todos os seres humanos precisam de algo que é externo a eles para 
sobreviver, a sobrevivência marcada, então, pela dependência de outro ou outros. Se a condição de precariedade possui estatuto ontológico, a possibilidade da violação (decorrente da precariedade), define a humanidade ${ }^{51}$. Ser violável (estar continuamente exposto e ser dependente a algo exterior a si), no entanto, não equivale a ser violado. A condição humana assim definida por Butler parece assumir condições extremas no cárcere, quando indivíduos encontram-se expostos a condição de extrema precariedade, em que a dependência de um outro (que se encontra do lado de fora das grades) marca o limite de sua própria sobrevivência. Nas narrativas do cárcere em geral, e na de Mendes em particular, há um esforço de tematizar a precariedade humana e sua condição de violação, que assumem, nos textos, a forma da violência tanto sofrida quanto exercida sobre os outros.

A violência e a experiência da dor abrem e fecham o livro de Mendes, embora elas nem sempre andem juntas. Após a retomada de toda a sua trajetória - repleta de momentos em que foi torturado mas também de outros em que praticou agressões contra terceiros - o autor não fala mais de violência, mas especialmente de dor. Ao final, como já foi dito, ele afirma que a dor ensina, principalmente a não mais desejá-la. No início, no entanto, o que se percebe é a violência a que era submetido pelo pai alcóolatra:

Por qualquer motivo, mandava que eu fosse buscar o cinturão de couro no armário e dizia, sadicamente, que iríamos ter uma conversa. Era uma tortura, era mesmo! Pegava pelo braço e batia, batia, batia... até ficar sem fôlego. Eu sentia que era com raiva, prazer até. Qual quisesse apagar todos os males de sua vida miserável. Eu gritava até não ter mais voz, pulava, esperneava e tentava me defender dando a parte menos dolorida do corpo às cintadas. Se é que havia alguma parte menos dolorida. Então me largava num canto, escondido do mundo, inteiramente só, chorando... Todo cortado por vergões roxos, querendo morrer para que ele sentisse culpa de minha morte (MENDES, 2001, p.10).

Essa primeira imagem é retomada diversas vezes ao longo da narrativa; a violência sofrida por Mendes, na maioria das vezes cometida por policiais, o fazia lembrar o pai e as surras da infância.

\footnotetext{
${ }^{51}$ Butler descreve o estatuto ontológico da precariedade ao afirmar: "Nós não nascemos primeiro e em seguida nos tornamos precários; a precariedade é coincidente com o próprio nascimento (o nascimento é, por definição, precário), o que quer dizer que o fato de uma criança sobreviver ou não é importante, e que sua sobrevivência depende do que poderíamos chamar de uma 'rede social de ajuda"' (BUTLER, 2015, p.32).
} 
A palmatória descia e subia, numa sucessão de dores e sensações dilacerantes que, de repente, uniam-se num estado único e insuportável de dor. O rapaz parecia disputar com o tira mais velho quem era mais competente em provocar dor. Era uma luta, e eu, o alvo, não tinha nem quinze anos. [...] Fui obrigado a admitir que fora eu quem roubara o veado, mas prometi, na hora, para mim mesmo, que, de mim, aqueles cães não saberiam mais nada. Eu os mataria, eu os trucidaria cortando-os em pedaços, a machadadas, na primeira oportunidade. O ódio zumbia em mim, vencendo o medo. Eles eram meu pai, eram a fome, o frio, a miséria, a solidão e a ausência de minha mãe. Eles eram tudo o que odiava no mundo (MENDES, 2001, p.61-62).

O carrasco, totalmente fora de si pela minha ousadia de correr dele, começou a bater às queimas, para acertar onde acertasse. E doía, doía... Lembrava meu pai, era quase a mesma tortura, só que ali doía infinitamente mais (MENDES, 2001, p.96).

Após algumas pauladas e ameaças, deram-me uma sacola para carregar, e fui levado a uma salinha no mesmo corredor. Lá havia dois cavaletes e um cano de ferro. Quando tiraram o conteúdo da sacola é que percebi que carregava os instrumentos de tortura. Ali estavam as ataduras, as cordas de náilon, os fios, os cacetes e a máquina de choques. Recordou-me meu pai mandando que eu buscasse a cinta para me bater (MENDES, 2001, p.333).

Nos momentos em que é vítima de violência, a figura paterna retorna, funcionando como marco narrativo de modo a dar sentido ao acontecimento; não como forma de compreender a violência em si, ou a tortura em casos específicos, mas como possibilidade de organizar os acontecimentos: não era a primeira vez que apanhava daquela maneira, já que o pai lhe fazia sofrer; assim que ainda na infância a violência também lhe escapava ao entendimento. Se a violência sofrida não é compreensível no momento presente, ela pode ser pensada e refletida a partir da busca na memória de uma experiência semelhante. A narrativa da violência ou sobre a experiência da violação organiza o entendimento acerca da violência vivenciada, sugere Veena Das $(1999,2007)$. É, nesse sentido, que o pai lhe vem a memória para organizar os eventos traumáticos de modo a que pareçam menos aleatórios ou arbitrários.

A violência não é apenas sofrida por Mendes, mas se apresenta como forma de se colocar no mundo e de se relacionar com as pessoas próximas, o que se revela, por exemplo, quando ele relata relações amorosas que manteve com mulheres e meninas que compartilhavam com ele a vida no crime. Em seus termos: 
A fúria me tomou. Fui para cima dela como um rolo compressor. Derrubei-a, passei por cima dela e comecei a chutá-la, pisar, com ganas de destruir, despedaçar. Oscar e as garotas invadiram o quarto e tentaram me agarrar e sobrou porrada para todos. Só quando o irmão do Oscar me pegou pelo pescoço e perdi o fôlego é que conseguiram me parar (MENDES, 2001, p.279).

A violência está assim presente em todas as dimensões da experiência: mostrar valentia é uma atitude valorizada no "mundo do crime", sendo que a coragem para agredir uma vítima, se necessário fosse, também é visto como algo valoroso entre os companheiros de Mendes. Mas, ao mesmo tempo, a violência aparece de forma ambígua na narrativa, pois se ele a reivindica como o atributo em algumas situações (ser violento), em seguida afirma que a violência, mesmo aquela praticada por ele, não fazia sentido:

Nos últimos tempos, minha cabeça mudara muito. Tinha a ver com tudo o que vivera nas prisões. Estava mais calculista, mais violento, prepotente, mais duro e até cruel, e pouca coisa me importava. Já não me preocupava se tivesse que atirar em alguém. Atiraria agora, sem vacilar. Achava que personificava o crime.

$[\cdots]$

No fundo, paradoxalmente, eu não era nada disso. Continuava a ser o menino assustado consigo mesmo, medroso e só, de sempre. Carente, profundamente angustiado e agora tenso para conseguir manter a imagem que queria que cultivassem de mim (MENDES, 2001, p.270).

A violência ou a valentia são percebidas não como atributos seus, mas como atributos do ladrão ou do "bandido" que ele gostaria de ser. A violência faz parte, assim, da imagem que Mendes quer construir de si para poder ter dos outros o respeito almejado.

A violência e a agressividade estavam tomando conta de mim. Aos poucos ia personificando o bandido. Vencia meus escrúpulos a cada instante e procurava liberar toda a minha revolta nas vítimas. Dava coronhada pelo menor motivo, até sem necessidade. Não tinha mais medo de ninguém e estava pronto para matar, se preciso fosse (MENDES, 2001, p.277).

Mendes projeta essa imagem de si: a do menino que foi se transformando em um homem que buscava o respeito a partir da violência que praticava, que fazia da valentia modo 
de reagir ao risco e à agressão. Como mostram alguns dos trechos acima citados, ele estava pronto para matar, "se preciso fosse". Mas, no momento em que isso aconteceu - quando mata um guarda de um posto de gasolina que reagiu ao assalto praticado por Mendes e seus companheiros, por exemplo - o evento teima em permanecer incompreensível:

Estava em choque profundo. Matara um homem. Fora tão fácil... Aquilo me deixava perplexo. Sempre pensara que seria difícil matar e em questão de segundos, apenas apertando gatilho, havia tirado uma vida humana. Não conseguia pensar acerca, parecia que não havia sido eu (MENDES, 2001, p.312).

Procurei eliminar a morte do guarda-noturno de minha mente, racionalizando que fora ele quem quisera assim, e sequer pensava que ele poderia ter mulher, mãe, filhos, família, que poderiam passar necessidades. Fora um ato do qual fugia de me culpar. Achava que não iria resolver nada, o sujeito já estava morto, e nada o ressuscitaria, nem meu arrependimento (MENDES, 2001, p.315).

Em momento posterior, quando já se encontrava preso e condenado no Carandiru, mais uma vez ele se vê em uma situação em que julgou ser preciso matar um homem para garantir a própria vida no presídio: Toninho, que tentava aliciar Mendes para fazer dele sua "esposa",52, arma uma cilada, em que Mendes é atraído para uma cela onde o rival se encontrava com um faca. Toninho procura submetê-lo sexualmente, ao que Mendes revida com maior violência, assassinando-o:

Não podia deixá-lo vivo. Ele me mataria, tinha certeza disso. Se entrasse alguém para defendê-lo, era preciso que ele já estivesse fora de combate. Toninho tentou se agarrar em mim e novamente recebeu toda a lâmina no peito. Caiu, subi por cima e procurei só furar o coração. Só parei quando o vi virando os olhos, estava morrendo, [...].

Fui à torneira, lavei as mãos, a faca, limpei o sangue que vi em minhas mãos e braços com um pano molhado e fui para a porta. [...] Não estava bem consciente, meus olhos estavam esbugalhados, a mente muito confusa, embora calma. Só queria que aquilo passasse, e logo.

[...] Desci para a carceragem, em choque, mas paradoxalmente calmo. Encontrei o carcereiro-chefe, dei-lhe a faca e contei o que ocorrera.

[...] Apenas quando me deitei, esgotado de cansaço, no chão gelado, é que fui estar plenamente consciente de mim. Tudo o que ocorrera durante o

52 Fazer de um detento sua "esposa” significa subjugá-lo sexualmente, submetendo-o a relações sexuais constantes, e também obrigá-lo à limpeza constante de sua cela. 
dia, inclusive o crime, parecia um pesadelo do qual houvesse acordado. Jamais foi um fato inteiramente real para mim, assim como a morte do guarda-noturno. Não sentia como tivesse sido realmente eu quem exterminara aquelas vidas. Tudo era nebuloso, meu sistema de autodefesa protegia-me dos fatos como se os envolvesse em casulos de aço e matéria de sonhos" (MENDES, 2001, p.362-364).

Para organizar narrativamente as experiências violentas, no limite sempre incompreensíveis, Mendes utiliza-se de dois subterfúgios: no momento em que é vítima, são as surras do pai os eventos trazidos à memória para organizar a experiência presente, conferindo-lhe um sentido, mesmo que precário; quando o autor se vê frente a eventos em que ele era o perpetrador da violência, por sua vez, a chave da narrativa modifica-se, e ele lança mão de artifícios pautados na produção de imagens, organizadas na chave do sonho, o que lhes confere certa ambivalência de sentido ("Sempre pensara que seria difícil matar e em questão de segundos, apenas apertando gatilho, havia tirado uma vida humana. Não conseguia pensar acerca, parecia que não havia sido eu”, [...] “Tudo o que ocorrera durante o dia, inclusive o crime, parecia um pesadelo do qual houvesse acordado", [...] "Tudo era nebuloso, meu sistema de autodefesa protegia-me dos fatos como se os envolvesse em casulos de aço e matéria de sonhos”).

As dificuldades, ou impossibilidades, de narrar o trauma e a dor são tematizadas por Carlo Severi (2000), a partir de contexto bastante diverso. Retirando inspiração nas formulações de Freud e amparando-se em sua etnografia sobre os Kuna do Panamá, o antropólogo discute como uma experiência dolorosa - no caso, as mortes e violências dos brancos contra os índios desde o contato - encontra dificuldades para ser organizada narrativamente e mesmo para se transformar em memória. Resistentes à lembrança, elas não são completamente apagadas da memória (nada o é, nos termos do Freud). Severi sugere que, no caso dos Kuna tal memória tem lugar em contexto ritual, por meio de imagens - e não de palavras - no qual o homem branco é presentificado com o auxílio de estatuetas, que têm lugar ambíguo nesses rituais: o branco é tanto vetor de doenças como auxiliar nos processos de cura.

Guardadas as devidas diferenças, o relato de Mendes também deixa ver uma recusa em guardar na memória um evento violento (seja da violência por ele sofrida ou pela qual foi responsável). Por isso mesmo ao longo da narrativa, ele tenta se valer de artifícios para organizar a experiência violenta sofrida, as surras do pai funcionando como uma chave de entendimento como vimos. Além da memória infantil, outro recurso empregado para dar 
conta da violência é o sonho. O recurso à narrativa onírica permite ao narrador uma espécie de dúvida, de licença poética que o permite se afastar do compromisso com a realidade, pautada na ideia da mimese: enquanto toda a narrativa é encadeada de maneira lógica, dando a conhecer a consciência do narrador em relação àquilo que se narra, no momento do assassinato de Toninho, o narrador é tomado de incertezas quanto à realidade dos fatos. Em seus termos:

Tudo o que ocorrera durante o dia, inclusive o crime, parecia um pesadelo do qual houvesse acordado. Jamais foi um fato inteiramente real para mim, assim como a morte do guarda-noturno. Não sentia como tivesse sido realmente eu quem exterminara aquelas vidas. Tudo era nebuloso, meu sistema de autodefesa protegia-me dos fatos como se os envolvesse em casulos de aço e matéria de sonhos (MENDES, 2001, p.364).

Se ao tratar da violência sofrida, Mendes se volta para a infância, tentando reencontrar ali um sentido para o sofrimento, a narrativa sobre a violência por ele perpetrada coloca dificuldades adicionais que ele tenta enfrentar recorrendo à imaginação onírica. Ao tratar sobre a violência na chave do sonho, Mendes deixa a interpretação em aberto, lançando possibilidade de dúvida sobre a autoria do fato. Note-se que ele não nega a autoria do assassinato e não coloca em dúvida o fato de Toninho ter morrido, mas, ao voltar-se aos acontecimentos que marcaram sua trajetória por meio de um esforço narrativo (o que traz um sentido para sua existência, como o autor afirmou), este evento permanece incompreensível para ele, sendo marcado como um momento em que a narrativa é incapaz de fornecer sentido para sua trajetória.

\subsubsection{A circulação da escrita e a produção do sujeito-autor}

A escrita de Mendes ultrapassa os muros da prisão: a publicação de sua autobiografia leva sua história para o conhecimento do público em geral e também o transforma em autor. Como ele mesmo afirma no epílogo de seu livro, "a ideia é escrever sempre e para sempre" (MENDES, 2001, p.409), quer dizer, a escrita ininterrupta permitiu que ele construísse um 
nome de autor: um novo sujeito que possui um lugar social, dentro e fora do cárcere. Apesar da construção desse novo nome, ainda assim Mendes encontra-se ligado à sua identidade de preso, ou ao seu prontuário ${ }^{53}$. Trata-se de um presidiário que se tornou escritor, e não um escritor que foi preso - como nos casos de Graciliano Ramos ou Dostoievski. Sua identidade como escritor foi forjada a partir de sua experiência no cárcere, e continua ligada a ele, como uma marca.

Em entrevista ao blog Livre Opinião ${ }^{54}$, publicada no dia 14 de outubro de 2014, Mendes, livre há dez anos, afirma que encontrava dificuldades em publicar livros que não fossem autobiográficos. Lembremos que à época da entrevista, o último volume da Trilogia de Memórias de um sobrevivente, (Confissões de um homem livre, 2015) ainda não havia sido publicado. Em outra entrevista, para a Revista Fórum (sem data), o autor afirma mais uma vez que encontra acolhida editorial apenas para a publicação de livros autobiográficos, e aponta um preconceito em relação ao seu passado como preso:

Eu sou metido a escritor, porque eles [as editoras] mesmos não me veem como escritor. Há um preconceito do caralho. Eles gostam muito de ler o que eu escrevo, mas não de falar que eu sou um escritor. [...] Estou com dois livros de ficção prontos aqui no meu computador. Porque eu não quero mais escrever sobre a minha pessoa. Já encheu o saco. Mas vou dizer, se quiser publicar, vou ter de escrever outro livro autobiográfico. Do que eu escrevo, a Companhia das Letras só publica esse tipo de relato, mais nada ${ }^{55}$ (MENDES, sem data, Entrevista à Revista Fórum).

Em todos os seus livros, quando ele é apresentado, há sempre a alusão à vida no cárcere. Na apresentação feita pelo blog Companhia das Letras, por exemplo, consta: "Luiz Alberto Mendes se tornou criminoso nas ruas de São Paulo. Escreveu essas memórias na prisão, onde cumpre pena por homicídio e outros crimes" ${ }^{" 56}$. No mesmo blog, quando o livro Às Cegas é apresentado, novamente se lê: "Luiz Alberto Mendes passou boa parte da vida em

\footnotetext{
${ }^{53}$ É bastante corrente, como pude perceber na pesquisa realizada anteriormente com agentes prisionais o reconhecimento do preso pelo seu número de matrícula (TAETS, 2012). André Du Rap fala da "carteirinha de bandido", que carrega mesmo depois de já ter cumprido sua pena de prisão. Essa identidade ligada a um número de matrícula - o prontuário - será discutida no último capítulo desta tese.

${ }^{54}$ Disponível em: http://livreopiniao.com/2014/08/14/entrevista-com-o-escritor-luiz-alberto-mendes-oslivros-me-salvaram/. Acesso em: 25/1/ 2016.

${ }_{55}$ Revista Fórum, "Luiz Alberto Mendes: 'Escrevo livros, mas não sou visto como escritor”, disponível em: https://www.revistaforum.com.br/semanal/luiz-alberto-mendes-escrevo-livros-mas-nao-sou-visto-comoescritor/. Acesso em: 7/4/2018.

${ }_{56}$ Disponível em: http://www.companhiadasletras.com.br/detalhe.php?codigo=11387. Acesso em 25 de janeiro de 2016.
} 
reformatórios e penitenciárias do estado de São Paulo" ${ }^{57}$. Na página oficial de outra editora, a Geração Editorial, por onde Mendes publicou Tesão e praz̧er, memórias eróticas de um prisioneiro (2004), consta sobre ele: "Luiz Alberto Mendes é paulistano, escreveu Memórias de um sobrevivente, um sucesso de público e de crítica. Cumpre pena de 74 anos por homicídio e assalto à mão armada" ${ }^{58}$.

Apesar da escrita de Mendes ter forjado uma nova identidade, a de autor, permitindo que se diferenciasse dos demais presos, tanto nos seus valores quanto naquilo que é capaz de produzir (o livro), a construção desse novo sujeito é inseparável da experiência do cárcere, quer dizer: ainda que busque ser reconhecido como um escritor, ele só é valorizado a partir de sua experiência específica, a de ter sido preso. O que revela ser a escrita no cárcere inseparável do intramuros, ainda que o texto produzido circule e alcance espaços distantes da prisão, carregando consigo o cárcere e o preso.

A prisão apresenta-se, portanto, como forma, como "enquadramento", no termos de Butler (2015), e como possibilidade da escrita, determinando os limites da produção do sujeito que será, mesmo a partir da prática da escrita e da publicação de um livro, sempre um sujeito preso, reconhecido como tal. Se por meio da escrita os autores da prisão buscam construir diferenciações em relação aos demais presos, elas não os levam para fora da prisão, alçando-os como autores simplesmente; eles são, desde o início e para sempre, autores do cárcere.

A escrita no cárcere, portanto, é fundamentalmente uma escrita da prisão: o texto não se descola jamais do seu contexto de produção. Isso se observa também na narrativa de Rodrigues, quando ele se debruça sobre a elaboração de um diário no qual narra, cotidianamente, as tarefas da escrita no cárcere, a elaboração desse sujeito autor, as tentativas de distinção em relação aos demais companheiros de prisão, algumas memórias e lembranças do sofrimento experimentado ao longo de sua pena, como veremos a seguir.

\footnotetext{
57 Disponível em: http://www.companhiadasletras.com.br/detalhe.php?codigo=11808. Acesso em 25 de janeiro de 2016.

${ }^{58}$ Disponível em: http://geracaoeditorial.com.br/tesao-e-prazer-memorias-eroticas-de-um-prisioneiro/. Acesso em 25 de janeiro de 2016.
} 


\subsection{HUMBERTO RODRIGUES: UM PRESO-ESCRITOR}

Humberto Rodrigues, assim como Luiz Alberto Mendes, se tornou escritor na prisão e sua escrita está, também, intimamente relacionada à sua experiência prisional. Rodrigues era jornalista e ocupou cargos executivos em grandes editoras, como a Abril e a Manchete. Em um dado momento de sua carreira, abriu mão destes cargos por insatisfação profissional, e passou, então, a enfrentar dificuldades financeiras juntamente com a desestabilização de sua família, tendo se separado da esposa e passado a viver sozinho numa pensão. É neste contexto de "terrível pobreza" (RODRIGUES, 2002, p.40), que se vê envolvido numa situação de contravenção, passando a ser procurado pela polícia e preso no dia 23 de maio de 2000, quando é encaminhado para o Depatri ${ }^{59}$; passa aí quarenta e três dias até ser encaminhado à Casa de Detenção. No Carandiru permanece por quinze meses, quando em novo julgamento é inocentado e recebe a liberdade. Esta é a breve apresentação que o autor faz de si na abertura de seu livro, Vidas do Carandiru - Histórias Reais; no entanto, é no decorrer da narrativa que tomamos conhecimento dos detalhes de sua trajetória, travando contato, principalmente, com os motivos que o levaram a escrever durante a estada no cárcere.

Assim que chega ao Carandiru, Rodrigues decide escrever um diário em que registra, cotidianamente, sua vida na instituição. A princípio, o diário serviria como uma atividade para controlar o tempo e ocupar a mente ${ }^{60}$. Aos poucos, no entanto, o autor opta por ampliar seus registros, passando a elaborar um livro que narra também histórias de seus companheiros de cárcere. A partir deste momento, o diário vê suas funções alteradas, passando a funcionar como instrumento de composição do livro projetado: as pesquisas realizadas nos pavilhões; as dificuldades em convencer os companheiros em contar suas histórias; os momentos de crise na escrita etc.

É pelo diário que tomamos conhecimento da estrutura que Rodrigues esperava dar à obra e o formato final que ele adquiriu; a princípio, o volume seria formado apenas pelas

\footnotetext{
${ }^{59}$ Depatri é o antigo Departamento de Investigações sobre Crimes contra o Patrimônio, onde havia uma carceragem para o qual eram enviados alguns presos à espera de julgamento.

${ }^{60}$ A tentativa de controlar o tempo e fixar o futuro por meio da escrita são frequentemente referidos como motivações para a prática de elaboração de diários. É por meio de um diário que Leiris, por exemplo, tenta dar sentido à experiência etnográfica vivenciada na África, buscando controlar a memória, o tempo, os sentimentos e o futuro (Cf. Peixoto in Leiris, 2007).
} 
histórias de seus companheiros, ao final, no entanto, o relato cotidiano é incluído como uma de suas partes, assim como são incluídas fotos do cotidiano do presídio, uma poesia de um companheiro de cela, um glossário dos termos utilizados na prisão e um mapa de tatuagens.

O diário tem início no dia em que Rodrigues chega ao Carandiru, 5 de julho de 2000, e termina três dias depois de sua libertação, em 21 de outubro de 2001. Embora o tempo passado no Depatri não faça parte dos registros diários, Rodrigues narra essa experiência específica no início do livro, que ele intitulou "O Futuro à Deus Pertence (Minha História)". Assim que o volume final por ele projetado, apesar de possuir estruturas textuais diversas (associando trechos de memórias, do diário e contos, além das imagens) almeja recuperar toda a experiência prisional de Rodrigues. Uma vez alterado o formato primeiro de jornal quotidiano, passando a tematizar a própria experiência de escrita, o diário de Rodrigues é o que ocupará a maior parte desta análise. Mas, claro está que é preciso considerar todo o livro para compreender o modo como o diário está nele inserido, o lugar que ocupa no interior da obra.

Além de um prefácio assinado por Ives Gandra, jurista e professor universitário, o livro de Rodrigues traz uma apresentação do próprio autor. Nela, ele aponta a importância da experiência vivida para a narrativa prisional:

Seria possível a um indivíduo, mesmo com grande capacidade de imaginação, conseguir passar a umas folhas de papel as trágicas experiências vividas por um preso? Sentir a mágoa e a tensão que vivemos a cada momento? Exprimir a angústia que sentimos devido à solidão e à falta de perspectiva futura? Se alguém sem essa experiência tiver a pretensão de escrever um livro sobre as histórias de um preso, sua vida ou mesmo o dia-a-dia de um presídio, olharei esse livro com incredulidade (RODRIGUES, 2002, p.11).

Assim que, para Rodrigues a importância de seu livro reside na força de uma narrativa que tem seu nascimento com a experiência prisional ${ }^{61}$. Rodrigues não escreve "ficção",

\footnotetext{
${ }^{61}$ A noção de experiência como algo fundamental para a construção da narrativa prisional não é algo próprio a Rodrigues, encontrando-se presente também em outros livros do cárcere (como em Ramos e André du Rap, por exemplo), e em todas as falas dos atores envolvidos com o cárcere. Este foi um tema bastante presente na pesquisa que realizei sobre agentes prisionais, quando elas afirmavam que apenas quem vive nas prisões tem legitimidade para falar sobre elas (ver Taets, 2012).
} 
Cada história deste livro [tratando dos contos sobre as histórias de vida de seus companheiros de cárcere] é um depoimento verdadeiro de um companheiro de prisão. São histórias guardadas atrás das grades e muralhas do Carandiru, o maior complexo presidiário da América Latina (RODRIGUES, 2002, p.12).

Fiel a esses princípios, Rodrigues se propõe a escrever um livro em que relate histórias de seus companheiros de prisão, "histórias reais", como traz o subtítulo do livro. Para tanto, durante o período que esteve preso, o autor procurou conhecer a fundo o cárcere: isso significou visitar outros pavilhões do Carandiru e também pesquisar os números e estatísticas dos presos na administração do presídio, o que contribuiu para dar ao livro um forte interesse documental ${ }^{63}$.

Além de funcionar como registro de dados e de fatos "verdadeiros", coletados com a ajuda de pesquisas realizadas pelo próprio autor, a escrita aparece também em seu texto como uma tarefa redentora; trata-se de escrever para sobreviver à prisão.

Além do mais, eu não poderia deixar de registrar esta experiência, esta lição de vida, que através da meditação nos dá mais humildade e resignação. Viver no Carandiru... Não importa se foram dois, cinco ou dez anos - o importante é constatar que sempre podemos ultrapassar nossos limites e vencer uma luta. Minha luta foi escrever este livro. Vencer as dificuldades naturais que se impõem a um detento. Escrever é mágico, sentia isso muitas vezes quando estava a ponto de desistir de tudo. Quando comecei a escrever, percebi que fazia mais do que apenas narrar histórias. Escrever é uma arma que pode tornar-se muito poderosa e perene. Transcendia as muralhas da prisão, sentia a vida fluir de novo. Podia ver os mártires escrevendo sob a eterna hipocrisia humana (RODRIGUES, 2002, p.11).

A escrita se impõe em função de seu caráter obrigatório: "Eu não poderia deixar de registrar esta experiência", ele diz. O que significa que ela deixa de ser efêmera e que, além disso, transcende os limites do espaço prisional, tanto no que tange o espaço (sua circulação para fora do cárcere) como em relação ao tempo, já que essa vivência específica se pereniza

\footnotetext{
${ }^{62}$ Rodrigues diferencia a "ficção" das "histórias reais" que constrói sobre seus companheiros de cárcere. É, portanto, essa concepção nativa de ficção que passo a utilizar para compreender a obra do autor.

${ }^{63}$ Enquanto esteve preso, ele teve acesso aos dados que o presídio produzia sobre a sua população criminal, com isso, foi capaz de produzir um mapa social do Carandiru daquele período, indicando a porcentagem de negros, brancos, pardos, faixa etária, escolaridade, tipo de crime cometido etc. Essas informações estão presentes no diário do autor em forma de tabelas na entrada de 14/4/2001, pp. 105-106.
} 
no relato. Mas, ao longo do texto é possível localizar outros significados atribuídos à escrita por Rodrigues, que a utiliza também como uma maneira de sobreviver ao cotidiano prisional, apresentado como opressor, tanto pelas privações, como também pelo tédio que invade aqueles que dele fazem parte. No trecho abaixo ele reflete sobre o modo como foi estimulado a escrever, indicando ainda o caráter disciplinador do exercício.

Vejo um cartaz convidando os presos a participar de um concurso de literatura, e penso: por que não tornar produtiva minha "estada" no Carandiru criando um livro, relatando todas as experiências de vida obtidas aqui? Sim, por que não transformar um limão numa limonada e quem sabe ajudar outras pessoas a não ter de passar por tudo isso? E outras ainda a entender o que é tudo isso, servindo quem sabe de subsídio para melhorarmos o sistema penal vigente no Brasil? A perspectiva de 'fazer valer' minha estada no Carandiru subitamente me enche de um novo ânimo, e me dá uma disposição redobrada de levantar todos os dias para meu novo desafio... Para encará-lo, rejeitei quase toda a esperança de ser solto tão cedo e tratei de disciplinar minha rotina aqui dentro. Desde coisas triviais, como a limpeza da cela, até a divisão do tempo de acordo com o meu trabalho e a elaboração do livro. Escrever este pensamento é parte disso. Subitamente, não me sentia mais como um preso, mas como um pesquisador que havia se proposto a permanecer durante algum tempo num local de privações para elaborar um livro (RODRIGUES, 2002, p.34$35)$.

Para realizar o seu projeto, Rodrigues forja para si uma nova identidade, a de pesquisador. A condição de preso, apesar de lhe garantir a experiência capaz de municiar a escrita, parece não lhe fornecer o distanciamento necessário para perceber esta experiência e transformá-la em narrativa. Seria preciso, portanto, olhar a prisão como um outro, nesse caso como um pesquisador, com a curiosidade daquele que observa de modo mais distanciado de maneira a compreender aquele universo, registrando-o. Tal postura de estranhamento do cárcere lança algumas pistas sobre sua condição, já que ele permanece ali como um estranho, como alguém que veio de fora - não apenas da prisão, como todos os outros, mas de fora de um universo que é trespassado pelo cárcere: Rodrigues não provém daquela parcela da população atravessada pelo recorte da delinquência, como demonstra Foucault (1987) ao tratar sobre as modernas políticas penitenciárias, que determinam, a partir de políticas de controle de populações, os grupos que serão passíveis de pena de prisão.

O exercício de estranhamento ao qual ele se lança permite entrever um recorte de classe, que se torna, aos poucos, evidente na narrativa de Rodrigues. A possibilidade de se ver 
como um estranho dentro do cárcere revela o lugar que ele assume frente aos seus companheiros de cela: um homem de meia idade, branco, de classe média, com nível superior, que não conhecia aquele universo antes de sua "experiência" no Carandiru. Ao chegar aí, o autor se depara com um universo novo, onde precisou aprender todas as regras, formais e informais, para sobreviver. $\mathrm{O}$ desconhecimento anterior do cenário prisional se expressa logo no início do texto, em que ele se preocupa, principalmente, em descrever a prisão na sua estrutura física, na divisão das celas, na maneira como os detentos se organizam com questões relativas ao sono e à limpeza etc. Apesar da descrição do espaço prisional estar presente em outros livros do cárcere (como no de André du Rap), o que marca a narrativa descritiva de Rodrigues é um espanto por encontrar dentro do cárcere uma organização e uma solidariedade entre os presos que ele afirmava não encontrar do lado de fora.

Rodrigues foi preso em maio de 2000, quando jantava em um restaurante em São Paulo; dali foi levado para a carceragem do Depatri, na mesma cidade, onde ficou detido por 43 dias, até ser encaminhado para a Casa de Detenção. O autor relata com detalhes as condições de sua prisão e as primeiras impressões ao chegar na cadeia. O que mais chama atenção em sua narrativa é a surpresa quanto à organização e à solidariedade entre os presos. O Depatri era marcado, à época, pela superlotação: de acordo com ele, 50 presos dividiam um espaço de $30 \mathrm{~m}^{2}$, sem janelas, apenas com a passagem para um cubículo de $1 \mathrm{~m}^{2}$ onde se encontrava a latrina, havendo 12 "treliches" de cimento nas quais os presos se revezavam para dormir ${ }^{64}$.

Rodrigues pauta a sua narrativa pela maneira como os presos se organizam para sobreviver, estabelecendo regras rígidas (de higiene, por exemplo), e constituindo fortes redes de solidariedade e de ajuda mútua.

A recepção foi cordial. Eu iria descobrir que os presos em geral são solidários e prestativos com seus companheiros. Procuram ser simpáticos, oferecem cigarros e o que tiverem para comer. A lei da cadeia, quando se entra em uma cela, é: em primeiro lugar, tirar os sapatos, vestir sandálias havaianas e tomar banho. Eu ainda estava com os pulsos intensamente doloridos das algemas quando terminei esse ritual, com sabonete e toalhas cedidos pelos novos companheiros. Logo em seguida devemos tomar atitudes e proceder como homens, para não sermos alvo de gozações e

\footnotetext{
${ }^{64}$ A carceragem do Depatri foi alvo de diversas denúncias por parte de entidades de defesa dos Direitos Humanos devido à superlotação e maus tratos dirigidos aos presos, tendo sido desativada oficialmente em 18/1/2001, pouco tempo depois da passagem de Rodrigues por essa instituição. Disponível em: http://www.saopaulo.sp.gov.br/spnoticias/lenoticia.php?id=8045\&c=6. Acesso em 15/7/2015.
} 
provocar reações que às vezes podem ser fatais (RODRIGUES, 2002, p.17).

Apesar de perceber que uma postura inadequada poder ser fatal, não é o perigo que chama a sua atenção, mas a postura que marca a relação entre os presos. O que se percebe é que, para ele, o espantoso era encontrar traços de solidariedade num local onde ele esperava imperar a lei do mais forte, observação recorrente que permite desenhar o lugar de enunciação do autor, recortado pela classe social a que pertence ${ }^{65}$ :

O ser humano costuma apontar os defeitos e fraquezas de seus semelhantes, e omitir as qualidades. Na cadeia é o inverso. Respeito e dignidade são fundamentais para os detentos. Fiz o possível para entender aqueles companheiros, em sua maioria pessoas simples e humildes, penetrar-lhes a alma, sentir suas dores, admirar-lhes sua relativa grandeza. Seja branco, negro ou pardo, velho ou moço, bom ou mau, ladrão ou assassino, não há preconceito algum. Exceto com os estupradores (RODRIGUES, 2002, p.18).

Depois de relatar a sua chegada à carceragem do Depatri e descrever a maneira como se dão as relações no seu interior, o autor narra aquilo que chamou de "Tragédia Dantesca", momento em que um dos presos agarra o carcereiro de plantão, rouba-lhe a arma e dispara um tiro que lhe acerta a mão. Como forma de punição pelo ocorrido, os policiais do Garra (Grupo Armado de Repressão a Roubos e Assaltos) invadiram a carceragem e torturaram os presos.

A “Tragédia Dantesca” apresenta-se como o ápice da narrativa relativa ao tempo em que passou no Depatri; relato que se opõe ao que virá a seguir: a descrição do Carandiru ${ }^{66}$. O Carandiru, apesar da fama que tinha à época como lugar difícil de sobreviver, aparece nos depoimentos e textos como um local onde os presos podem cumprir suas penas com um pouco mais de dignidade. Claro que se trata de uma dignidade relativa, afirmada quando contraposta ao "inferno" vivenciado na carceragem anterior ${ }^{67}$. O Carandiru é descrito por

\footnotetext{
${ }^{65}$ André Du Rap, como vimos, também chama a atenção do leitor para a solidariedade dos presos, no entanto, não o faz com o mesmo espanto que Rodrigues demonstra frente ao que lhe parece inesperado.

${ }^{66}$ Tal contraponto também aparece em André du Rap, quando as antigas carceragens são descritas como locais propícios aos abusos policiais e à tortura.

${ }^{67} \mathrm{O}$ sujeito que é preso, antes de ser julgado e condenado, quando então é encaminhado a uma unidade prisional, deve ficar em um abrigo especial. Até a década de 1990, no estado de São Paulo, 45\% dos presos se encontravam sob custódia da Secretaria de Segurança Pública, alocados nas carceragens das Delegacias de
} 
Rodrigues como um local onde o preso pode trabalhar, existindo pavilhões nos quais as celas são habitadas por três ou quatro pessoas, onde se recebem visitas aos finais de semana e há acompanhamento médico. "Prisão é uma palavra tenebrosa, mas em um distrito policial é mais tenebroso ainda, escabroso, uma escara com purulência que não pode ser ignorada" (RODRIGUES, 2002, p.31).

Para finalizar o trecho do livro que o autor chamou de "Minha história" e dar início ao seu diário, ele desenvolve uma seção intitulada "Ironia e injustiça", na qual relata os acontecimentos que culminaram na sua prisão. Rodrigues abre esta seção com um questionamento:

Mil vezes eu pensei: conto ou não conto? É horrível estarmos a remexer em um fato incompreensível. Além disso, seria lamentável os leitores interpretarem a minha história como uma versão para defender-me. Por outro lado, seria justo omitir as circunstâncias e os fatos que culminaram com a minha prisão e simultânea condenação? Justamente eu que, através deste livro me propus a contar tantas histórias de condenados? Seria justo me excluir? (RODRIGUES, 2002, p.39).

Percebe-se aqui um questionamento acerca da credibilidade de seu relato: quem daria ouvidos a um presidiário? E se ele alegasse inocência ${ }^{68}$ ? Contar os fatos que levaram ao aprisionamento poderia ser interpretado como uma tentativa de convencer o leitor acerca da sua inocência, e ao fazê-lo, ele acreditava que poderia perder a credibilidade em relação ao relato. Por isso a dúvida: “Conto ou não conto?”. Esta insegurança do autor frente à credibilidade que poderá ser dada ao texto também está presente em outras narrativas prisionais. Palmeira (2009) afirma que há um padrão nestes textos, que é a mobilização de

Polícia, de acordo com dados do $5^{\circ}$ Relatório Nacional sobre os Direitos Humanos no Brasil (DIAS, 2012). Com a política de ampliação do sistema prisional, na década seguinte, essa porcentagem caiu vertiginosamente a despeito do aumento em números absolutos da população prisional - para a casa dos 10\%; ao final da década de 2010, esse número caiu mais ainda, atingindo a marca dos 5\%. Com a ampliação do sistema prisional foram criados os Centros de Detenção Provisória, conhecidos como CDP, para onde os presos provisórios - que aguardam julgamento - devem ser encaminhados. Com essa mudança, retira-se da Secretaria de Segurança Pública, que custodiavam as antigas carceragens, a responsabilidade sobre as pessoas presas, ainda que provisórias, transferindo-a para a Secretaria de Administração Penitenciária. Apenas na última década foram inaugurados 7 CPD's no estado de São Paulo, de acordo com dados da Secretaria de Administração Prisional de São Paulo. Disnponível em: http://www.sap.sp.gov.br/uni-prisionais/novas-uni.html. Acesso em 16/8/2017.

${ }^{68}$ No início de minha carreira como pesquisadora no cárcere, quando me preparava para realizar entrevistas com pessoas presas, ouvi de meus colegas de trabalho: "Tome cuidado para não acreditar em tudo o que o preso diz, na cadeia, todos são inocentes!”. Nesse conselho já se desenhava uma questão que mais tarde seria retomada por mim para pensar sobre os discursos do, e no cárcere, e suas relações com a sociedade extra muros: por que as narrativas do cárcere procuram sempre construir uma noção de verdade? E por que tais narrativas são vistas, sempre, como suspeitas? 
alguns elementos da experiência vivida no cárcere como forma de atestar que o que está sendo narrado de fato se passou com eles, buscando construir um referencial inequívoco para a narrativa. Ela identifica nestes autores (em Rodrigues, mas também em André du Rap, Luiz Alberto Mendes e Jocenir, autor de Diário de um detento) um temor, reiteradamente expresso, de que o que estava sendo dito ali não fosse levado à sério pelo leitor, justamente pela condição de presidiário dos autores (PALMEIRA, 2009, p.10).

A saída de Rodrigues diante da possibilidade de dúvidas da veracidade do seu relato é apostar na força de uma narrativa pautada na experiência, o que para ele seria a garantia da legitimidade do texto:

Finalmente, depois de pensar e repensar sobre o assunto, decidi que o certo seria contar. Ser tão transparente como foram os meus companheiros. É apenas uma satisfação aos meus leitores, mesmo porque já passou tanto tempo e não será essa exposição que vai mudar alguma coisa. Não importa quem vai acreditar ou não, será apenas uma pequena história. Apenas um desabafo. Desabafo de um evento que transformou radicalmente minha vida (RODRIGUES, 2002, p.39).

Fica a critério do leitor, portanto, acreditar ou não naquilo que Rodrigues está narrando. E é a esse leitor que o autor dirige o esforço de conferir coerência à narrativa: não contar os fatos que o levaram à prisão seria privá-lo de uma parte primordial de sua trajetória, colocando em dúvida todo o relato.

Não é apenas Rodrigues que se ocupa do questionamento em relação à autoria dos acontecimentos que o levaram à prisão. Mendes também se depara com ela quando relata a violência por ele perpetrada contra o guarda noturno e contra o rival no cárcere, problema que ele enfrenta narrativamente pelo recurso ao sonho, como vimos. André du Rap, por sua vez, narra as condições de seu aprisionamento, ainda que sem se deter sobre a autoria do crime pelo qual foi condenado. Isso para dizer que se a prisão figura como condição de possibilidade dessa modalidade específica de escrita (os escritos do cárcere), ocupar-se das condições da existência da prisão na experiência do autor (os fatos ou contextos que o transformam em um preso) torna-se, portanto, um imperativo da própria narrativa: é preciso narrar os fatos que culminaram na prisão de cada um dos autores. $O$ cárcere, portanto, constrange seus autores a narrarem a própria prisão, o que nos permite afirmar que esta prática da escrita não é baseada em um exercício de liberdade: a prisão determina seus 
escritos de formas diversas, como já foi indicado, funcionando como "enquadramento" (no sentido butleriano), como conteúdo, e também como marco que possibilita o nascimento da escrita no cárcere, não sendo possível escrever a partir do cárcere sem tomá-lo como origem da própria escrita.

\subsubsection{O contar dos dias: a elaboração de um diário}

O diário de Rodrigues conta com um prólogo em que o autor reflete sobre o próprio ato de manter um diário, e indica ainda caminhos para sua análise:

O homem de ação raramente mantém um diário, mas é quase sempre mais tarde, por meio de anotações, que recordamos e aprendemos meditar, e, na maioria das vezes, nos surpreendemos e verificamos que não somos os únicos a olhar face a face para o futuro inexorável (RODRIGUES, 2002, p.47).

A prática de escrita de um diário, para Rodrigues, mais que uma ação voltada para o controle das atividades cotidianas e esforço de compreensão do passado volta-se para o presente e também como maneira de encarar o "futuro inexorável". Trata-se de uma prática de agenciamento do tempo na prisão, conferindo caráter produtivo às atividades e oferecendo um sentido ao tempo cheio de tédio da prisão.

A primeira entrada do diário é marcada pelo dia 5 de julho de 2000, momento de sua chegada no Carandiru, e a última acontece no dia 21 de outubro de 2001, três dias depois de ter sido liberto, e é quando ele opta por terminar a sua narrativa.

Usufruo da minha liberdade com toda intensidade. Que delícia! Aprendi a ser feliz com as coisas mais simples, que na vida são as mais belas. Este é o fim das noites mal dormidas, da solidão, da tensão, da ausência de liberdade... É o final desta história (RODRIGUES, 2002, p.144, entrada de 21/10/2001, grifo nosso). 
A estada de Rodrigues na Casa de Detenção é o que determina os limites da narrativa que ele se propõe a contar, não interessando dizer ao leitor o que aconteceu depois. É ali que ele se reconhece como autor e que se identifica com um "pesquisador", o que inscreve o seu texto em um tempo - o da condenação - e um espaço - a prisão. Todo seu esforço em garantir credibilidade ao texto é pautado nesta realidade - Rodrigues não é um autor que foi preso, mas um preso que se tornou autor enquanto estava preso. Ao refletir sobre a tarefa de escrever sobre a história de seus companheiros, o autor afirma:

Vi como é difícil escrever uma história e fico imaginando como certos escritores conseguem produzir obras de quinhentas páginas ou mais. Já li livros que o romancista levou 30 anos para escrever. Não tenho essa pretensão, afinal minha pena é de cinco anos e quatro meses e, caso não seja absolvido na apelação, tenho certeza de que sairei antes, pois pretendo ser um preso muito bem-comportado (RODRIGUES, 2002, p.63, entrada de 4/10/2000, grifo nosso).

O advérbio afinal caracteriza o motivo pelo qual Rodrigues não tem a pretensão de escrever um romance de quinhentas páginas ou mais, tampouco levar trinta anos para escrever uma obra: seu tempo de pena é de apenas cinco anos e quatro meses, tempo insuficiente, segundo sua visão, para escrever uma obra de grande magnitude. O que assegura que Rodrigues não dará continuidade ao seu livro depois de liberto, quer dizer: ele não pretende ser um escritor, apenas escreve enquanto se encontra preso, já que o conteúdo de sua escrita é exatamente sua experiência prisional, assim como a daqueles que se encontram presos com ele. Rodrigues, portanto, pode ser classificado como um homem que, enquanto se encontrou preso, se dedicou à elaboração e produção de um livro para narrar exclusivamente a sua experiência no cárcere.

Apesar de ter a primeira entrada no dia 5 de julho de 2000, é no dia 8 de julho, três dias depois de seu encarceramento, que Rodrigues dá início, de fato, à elaboração do diário: "Agora tenho uma mesa para trabalhar e condições de escrever este diário, onde pretendo registrar os fatos mais relevantes do dia a dia e, quem sabe, mais tarde escrever um livro" (RODRIGUES, 2002, p.51). Depois de passar pela triagem - local onde os presos recémchegados recebem as primeiras instruções em relação ao presídio e passam pela burocracia -, Rodrigues recebeu, já de início, um posto de trabalho: seria datilógrafo, arquivista e estafeta, tendo em vista seu conhecimento anterior na área. 
No terceiro dia então ele decide elaborar um diário onde pretendia "registrar os fatos mais relevantes do dia a dia e, quem sabe, mais tarde escrever um livro" (RODRIGUES, 2002, p.51). Seu diário volta-se para esse registro cotidiano que tem início com uma descrição da Casa de Detenção e das pessoas que vivem ali. Há, inicialmente, um desejo de registrar tudo, o que pode ser percebido também pela frequência das entradas: nos primeiros dez dias, ele escreve diariamente, em seguida, sua escrita torna-se mais espaçada e os temas tratados modificam-se, voltando-se, principalmente, para a tarefa da escrita e as dificuldades de um cotidiano marcado pelo tédio e pela sensação de que os dias são todos iguais.

Depois de escrever sobre sua trajetória, ele parece ganhar fôlego para narrar outras histórias - as de seus colegas de prisão - decidindo juntar todas elas e formar um conjunto. O diário segue, então, como uma anotação diária das dificuldades e dos prazeres da elaboração desta obra, funcionando como uma estratégia para complementar as narrativas de seus colegas e a sua própria, de maneira a dar autenticidade ao texto:

\begin{abstract}
Depois de alguns dias pensando e meditando sobre o assunto resolvi encarar o desafio de escrever um livro. A crônica que escrevi para o concurso literário, apenas sete páginas de sulfite datilografadas, estou transformando em uma história, na qual procuro, nos mínimos detalhes, transportar o leitor para a experiência mais dramática de minha vida. Posteriormente, pretendo escrever algumas histórias de meus companheiros e finalmente complementar com esse diário, tudo autêntico, mostrando o dia a dia de um grande presídio, seus dramas, alegrias e tristezas. Não sei se vou conseguir, mas vou tentar, pretendo também inserir algumas fotos e ilustrações elaboradas pelos próprios presos. Aqui temos alguns que têm esse dom. O Leno é um deles e já se prontificou a colaborar. Estou entusiasmado. Sei que as palavras formam os fios com os quais tecemos nossas experiências e, pelo que vislumbro, não serão poucas. [...] Não posso deixar-me consumir pela revolta, amargura e desespero. $\mathrm{O}$ objetivo de escrever esse livro há de me ajudar bastante. O desafio é apreciar as coisas boas da vida, em vez de ficar reclamando (RODRIGUES, 2002, pp.56-57, entrada de 15/8/2000).
\end{abstract}

$\mathrm{Na}$ entrada seguinte a essa, Rodrigues começa a descrever as dificuldades que encontra na escrita do livro:

Terminei a minha história para o livro e, antes de começar a escrever a primeira história de um companheiro, fico maquinando como fazer. É uma experiência nova, que me empolga e, ao mesmo tempo, me atemoriza. Mas vou tentar, adoro desafios. [...] No pátio, fico analisando meus 
companheiros e indagando a mim mesmo como será o meu primeiro personagem (RODRIGUES, 2002, p.58, entrada de 10/9/2000).

Em seguida, no dia 11/9/2000, dá prosseguimento às anotações sobre sua pesquisa para o livro e relata que visitou outros pavilhões no intuito de conhecê-los.

Estou tentando aproveitar o máximo o "passe interpavilhões" que consegui. A exemplo das visitas que fiz aos Pavilhões VIII e IX, ontem fui conhecer o IV e o V, e hoje os Pavilhões VI e VII. Não é muito aconselhável ficar se expondo no meio de tantos desconhecidos, embora a calça bege sirva de senha para encontrarmos alguma solidariedade. O ideal é não se "coçar" muito e ficar quieto no seu canto. Mas escrever um livro sobre o Carandiru, sem conhecer todos os pavilhões, é muita pretensão. Agora, pelo menos, já tenho alguma ideia, porque para conhecê-los é necessário no mínimo três meses, isso morando neles, vivenciando durante as 24 horas o clima, abominavelmente sombrio, a sujeira, o barulho, o vício e a miséria (RODRIGUES, 2002, p.59, entrada de 11/9/2000).

Mais uma vez, Rodrigues aponta para a experiência como o elemento essencial para narrar o presídio. Para falar sobre a prisão é preciso conhecê-la como presidiário, como aquele que esteve "do lado de lá" das grades. Rodrigues busca, então, transitar pelo presídio exatamente para ter esse conhecimento. Ou seja, ele também, apesar de preso, não teria "autoridade" para escrever sobre o Carandiru, já que sua experiência se restringe a alguns pavilhões. Procura, então, conhecer os demais, mesmo correndo o risco de se expor, como ele mesmo diz, na entrada citada acima.

Ao relatar as dificuldades na elaboração de seu livro, chama a atenção para o seu principal desafio: o pouco interesse dos demais presos em narrar suas próprias experiências. Ele insinua, desse modo, que seu esforço e interesse não são compartilhados por todos, e o autor compreende essa dificuldade como resultado daquilo que avalia como "baixo nível cultural" dos seus companheiros:

Só penso em escrever o livro. Sei que vou encontrar muitas dificuldades. Normalmente o preso, em função do seu baixo nível cultural, não tem a mínima noção de como contar a história. Se não fizer perguntas, já percebi que não sai nada. Tem de ser na base do: como, quando, onde, por que e quanto custa? Temos de perseguir, através de milhares de registros, a atualidade dos fatos, muitas vezes esquecidos, tentar restituir a mobilidade, 
a leveza dessas lembranças há muito adormecidas, aproveitar o que há de mais duradouro, de essencial, nas emoções dos sentidos e nas operações que o levaram a pagar sua dívida com a sociedade. Terei de tomar notas, tudo em manuscrito, para depois criar um roteiro, datilografar e se necessário copidescar quantas vezes forem necessárias. Acho que dessa forma conseguirei algo útil, que possa se transformar em uma história, e as histórias em um livro. Às vezes passo horas e horas pensando no que escrever. Na cadeia existe muita rotina e disciplinas, acrescente-se a isso a falta de jornais, revistas e livros, e consequentemente a falta de pesquisa. Fico na ansiedade e na vontade escrever, para ver mais história pronta (RODRIGUES, 2002, p.61).

Ao elaborar um livro, portanto, ele se reconhece como um sujeito diferente daqueles que o cercam na prisão. No trecho acima, é possível perceber que o autor identifica o outro como "o preso", e é este preso, diferente dele, que possui baixo nível cultural, e por isso não teria condições de contar uma história com começo, meio e fim. Parte dele, assim, a iniciativa de transformar narrativas fragmentadas em uma história que seria, em sua visão, coerente. A escrita voltada para a elaboração de um livro, portanto, é percebida como uma prática que o afasta dos companheiros de cárcere, garantindo-lhe uma identidade mais próxima a de seu leitor do que de seus companheiros de carceragem.

Neste sentido, a sua concepção de escrita aproxima-se daquilo que venho chamando de esforço de diferenciação entre a sociedade exterior ao cárcere e o cárcere a partir da presença ou ausência da escrita, tendo como base as sugestões de Goody (2012), já mencionadas. É pela produção de um livro que Rodrigues procura se diferenciar dos demais, afirmando que não faz parte daquele universo (em que os indivíduos não sabem contar uma história ou não possuem interesse em fazê-lo). Em dado momento, no entanto, ele se surpreende com o grande número de presos que enviaram suas histórias para o mesmo concurso que ele (Letras de Liberdade, volume que será analisado mais à frente), totalizando 345 presos inscritos. Destes, apenas quinze foram selecionados para compor o livro coletivo.

Ainda que diversos presos escrevam (o número de inscritos no concurso é apenas uma das formas de perceber essa prática recorrente no cárcere), Rodrigues não os reconhece por meio da escrita, reafirmando que é a (sua) escrita que o diferencia dos demais. Isso se dá, segundo ele, pela estrutura privilegiada de seu texto: uma história que possui "leveza", ao mesmo tempo que dá "conta da dramaticidade da realidade carcerária". A narrativa do autor se afastaria da oralidade que ele localiza em outros textos do cárcere: ele não utiliza as gírias próprias do presídio e não se reconhece na fragmentação dos poemas ou letras de rap presentes em outros volumes oriundos do cárcere, como em André du Rap, por exemplo. 
Percebe-se, portanto, que o que o diferencia é um tipo específico de escrita, orientada desde o início para a publicação de um livro. O que nos leva a inferir que a prática da escrita, apesar de intensamente presente no cárcere, é capaz de produzir diferenças a partir de diversidade dos estilos escriturários, em que aqueles que se aproximam do formato do livro e vislumbram a possibilidade de uma futura publicação se reconhecem como sujeitos mais próximos da sociedade extramuros, enquanto aqueles que escrevem a partir de registros orais, orientados por outros propósitos, se encontrariam mais distanciados dessa mesma sociedade.

Palmeira (2009) indica o ponto quando diz que os autores do cárcere buscam construir um pertencimento ao "mundo dos homens livres" por meio da publicação de seus livros, construindo assim o "sujeito-autor". Apesar de concordar com ela, acredito que a escrita no cárcere não efetiva completamente o pertencimento dos autores presos ao "mundo dos homens livres", como vimos com Mendes, que, apesar de ter seis livros publicados, afirma não ser reconhecido como um escritor, mas sempre associado à prisão - sendo um escritor-presidiário mesmo quando em liberdade. De todo o modo, a escrita no cárcere e a publicação de livros constroem diferenciações no interior da prisão; é no cotidiano prisional que tal diferenciação é elaborada e gerida a partir da prática da escrita.

O diário de Rodrigues ganha importância para esta análise já que se revela como uma espécie de ateliê de escrita do autor. Por meio dele, o autor busca exibir, deliberadamente quem está por trás da tarefa, indicando as dificuldades que o cárcere oferece também a esta prática. Se a experiência do cárcere o levou à escrita, a atividade encontra-se atravessada por dificuldades típicas da prisão. O autor aponta, por exemplo, o medo de "pegar um bonde" (ser transferido para outra unidade prisional sem aviso) sem poder pegar seus pertences, o que significaria perder os originais de seu livro (RODRIGUES, 2002, p.114), temor parecido ao de André Du Rap, que temia a destruição de seus originais por ocasião de uma blitz, na cela (DU RAP, ZENI, 2002, p. 48). Lembremos que os escritos do cárcere são produzidos a partir do uso de papel, lápis e caneta, tendo como suporte um material que pode ser destruído mais facilmente, o que o torna frágil frente a uma instituição que restringe ao máximo o uso de elementos materiais.

Os dois volumes aqui analisados revelam importantes relações entre o cárcere, a escrita e o controle do tempo. Ao escrever uma autobiografia, Mendes procura reviver sua história e organizá-la, de forma a controlar passado e futuro. Rodrigues, por sua vez, escreve não tanto para controlar a experiência pretérita, como faz Mendes, mas para organizá-la no presente, "fazendo valer" sua estada no Carandiru. Nestas duas obras, no entanto, é possível 
perceber uma escrita voltada para a elaboração e possível publicação de um livro: Rodrigues, já no início de seu diário, afirma que procurará publicar seu livro, para trazer ao público o conhecimento de uma experiência que ele considera única. Mendes, a princípio não escreve sua autobiografia com o intuito de publicá-la, é Bonassi quem o incentiva a tanto. Mas, de todo o modo, é a publicação dos livros que permite a transformação destes sujeitos - presos - em autores, e é essa nova identidade que faz deles sujeitos diferentes. Tal diferenciação pode ser percebida em duas esferas: os autores não só são percebidos de forma diferente pelos demais presos como também elaboram uma nova identidade que extravasa os muros do cárcere, o que leva a que sejam percebidos como diferentes pela sociedade extramuros. Mas a forma como são percebidos pela sociedade exterior ao cárcere não se realiza exatamente da forma como esperavam os autores, como veremos a seguir.

\subsection{UM PROJETO FRUSTRADO E A CONSTRUÇÃO DE UM SUJEITO HUMANO}

O cárcere apresenta-se, nas obras analisadas, como condição de escrita, de enunciação, de entendimento do mundo e como forma e conteúdo, como vimos. A escrita também produz distinções: os autores em questão, ao se debruçarem sobre suas memórias e trajetórias, elaboram textos e a partir deles se reconhecem como diferentes dos demais presos, passando a se reconhecer (e a serem reconhecidos) como autores em um contexto em que pouquíssimos alcançam esse status. Ao publicarem seus livros, Mendes e Rodrigues tornam-se autores, o que expande a diferenciação: eles passam a ser reconhecidos, publicamente, como pessoas-presas que escrevem livros.

Do ponto de vista da instituição prisional, a prática da escrita é valorizada como uma atividade que permite o autoconhecimento, caminhando, portanto, na direção da ressocialização, como veremos no próximo capítulo. Mas para Mendes e Rodrigues, mais que uma prática de autoconhecimento ou ressocializadora, a escrita revela-se como um esforço em construir, por meio do exercício da memória e do controle do tempo, um sujeito outro, diferente dos demais. Esse empenho, no entanto, não se parece a uma necessidade de autoafirmação frente aos demais detentos, mas antes, como um exercício moral de modo a 
não ser percebido como "monstro", imagem que o sujeito do clichê "bandido bom é bandido morto" carrega. Assim que se a prisão constrói o "bandido", a prática da escrita permite a construção do sujeito humano: ao narrarem suas histórias, dando conta dos acontecimentos da infância, adolescência, iniciação na vida no crime, torturas sofridas por policiais, distância e saudade dos familiares, agruras vividas no cárcere, dificuldades na prática da escrita, etc., esses sujeitos chamam a atenção para a precariedade que marca as suas vidas, reconstruindo um entendimento sobre si próprios: seja como for, são seres humanos ${ }^{69}$ (BUTLER, 2015).

Quando Fassin e Rechtman (2009) se debruçam sobre a categoria de trauma buscando elucidar a história moral que determina as percepções acerca da experiência traumática, os autores afirmam que a ideia de vítima vai se constituindo ao longo da história recente a partir de uma disputa de responsabilização em relação aos danos pessoais causados pelas guerras. Se, num primeiro momento, aqueles que se feriam nas guerras ou em trabalhos que envolviam riscos eram percebidos como pessoas de má fé ou má índole, que buscavam se subtrair do trabalho e da responsabilidade frente à pátria, nas últimas décadas, quando temos a presença de um grande número de refugiados e veteranos de guerra em situação de estresse pós traumático, a noção de vítima se altera, passando a funcionar como um marco de responsabilização do Estado frente às vítimas produzidas durante a guerra. $\mathrm{O}$ interessante a notar é que essa responsabilização - e portanto, a própria noção de vítima - engloba tanto aqueles que perderam suas vidas ou sofreram danos irreversíveis nas guerras, como também os combatentes, aqueles que, em momentos anteriores, eram considerados os perpetradores da violência. Essas são, todas, vítimas humanitárias, já que sofreram, a partir de posições diferenciadas, as agruras e violências de uma guerra.

Retomo aqui o argumento de Fassin e Rechtman em torno da elaboração da noção de vítima humanitária para pensar as formas pelas quais uma percepção social é elaborada moralmente. Segundo os autores, seria a capacidade de sofrer um tipo específico de sintoma - o estresse pós traumático - o que incluiria os agentes da guerra na categoria de vítimas humanitárias. Aqueles que perpetraram violências indizíveis também passam a ser

\footnotetext{
${ }^{69}$ Ao trabalhar a questão do reconhecimento que estabelece uma vida humana como vida, o que significa que esta deveria ser lamentada quando perdida - o direito ao luto - Butler afirma que este reconhecimento é resultado de operações de poder que constroem disposições afetivas e éticas de modo seletivo e diferenciado (2015, p.13). As molduras que estabelecem nossa compreensão ou apreensão sobre a vida são culturalmente dadas, tendo como base uma disposição normativa. A autora lança um questionamento acerca das possibilidades de ampliação deste reconhecimento, nos seus termos: "O que poderia ser feito para produzir um conjunto de condições mais igualitário da condição de ser reconhecido? Em outras palavras, o que poderia ser feito para mudar os próprios termos da condição de ser reconhecido a fim de produzir resultados mais radicalmente democráticos?” (2015, p.20).
} 
considerados vítimas, já que foram, eles também, afetados por uma guerra cruel na sua essência.

Os escritos do cárcere, como venho demonstrando, buscam elaborar ou reelaborar noções morais sobre o sujeito que escreve, em um movimento parecido com aquele que Fassin e Rechtman narram sobre a construção da vítima humanitária: ao descrevem suas experiências e demonstrarem o quanto também foram vitimados pela violência e pelo sistema prisional, estes autores buscam reelaborar uma noção que os toma como "monstros", ou seja, "bandidos", criminosos, foras da lei, transformando-os em seres humanos, que, apesar da violência que lhes foi imputada, também são seres precários, que dependem do outro para garantirem a própria existência.

Em entrevistas realizadas após o período em que esteve preso, Mendes se ressente de não ter conseguido se tornar um escritor tout court, já que continua, mesmo depois de liberto, a ser visto como um ex-presidiário que escreve. Assim que o seu intuito de constituir um sujeito-autor não é plenamente alcançado, mesmo com a publicação constante de livros após sua saída da prisão. Mas ainda que ele e também Rodrigues não tenham alcançado o estatuto de autores, eles redefinem o "enquadramento" relativo ao sujeito-preso, e o fazem por meio da escrita.

Ao se tornarem presos que escrevem, tais autores reelaboram a categoria de ser humano, que inclui a escrita como um elemento essencial; afinal, apenas seres humanos escrevem. A escrita no cárcere é responsável pela produção de sujeitos bumanos. 


\section{CAPÍTULO 3}

\section{CONCURSOS PRISIONAIS: RESSOCIALIZAÇÃO E RESISTÊNCIAS}

A prática da escrita no cárcere é considerada uma atividade ressocializadora pela instituição prisional, o que pode ser reafirmando a partir da análise de um conjunto de textos resultantes de concursos prisionais. Se os autores até então examinados permitem o contato com produções textuais que têm na publicação final de livros assinados a sua motivação e/ou seu principal resultado, os concursos permitem conhecer outro tipo de criação escrita, em que as obras dela originadas não são elaboradas individualmente ou em pares, como vimos anteriormente, mas resultam de um esforço coletivo, estimuladas por iniciativas institucionais, que viabilizam a edição dos textos. A publicação desses volumes permite-nos ter acesso a outros aspectos da escrita no cárcere, que destacam as tensões e disputas nela envolvidas, já que tais livros são produzidos em meio a relações sempre tensionadas entre a instituição prisional, que vê na escrita um meio de reinserir o preso na vida social, e os presos, que a interpretam e a praticam com intenções muito diversas. Esses descompassos de expectativas e seus desdobramentos, tanto para a prática da escrita no cárcere quanto para a sua circulação, é o interesse maior deste capítulo.

As obras ora analisadas diferem das anteriores não apenas por seu caráter coletivo, mas também por não terem no Carandiru sua origem exclusiva. Letras de Liberdade (2000), volume produzido em função de um concurso literário realizado em algumas penitenciárias de São Paulo, conta com a publicação de quinze textos premiados, sendo que nove deles foram escritos por presos cumprindo pena no Carandiru; dentre os demais, tem-se a presença de algumas autoras (são onze textos de autoria masculina e quatro de autoria feminina), o que também diferencia este conjunto de textos dos anteriores, formado apenas 
por autores homens ${ }^{70}$. O segundo volume analisado, O Direito do Olhar (2009), por sua vez, é resultado de um concurso artístico voltado especificamente para o público feminino, em que tanto mulheres presas quanto adolescentes cumprindo medidas sócio educativas e também agentes prisionais femininas tiveram suas criações (que incluem textos literários, desenhos e fotografias) avaliadas e premiadas. Em relação às instituições de Medidas Sócio Educativas, o concurso premiou internas de quatro unidades: Internato Parada de Taipas, HCTP, Tulipa e Internato Feminino Mooca. Já as instituições prisionais premiadas foram: Penitenciária Feminina da Capital, Penitenciária Feminina do Butantã e Penitenciária Feminina do Tatuapé. Ao total, o concurso premiou 43 trabalhos entre as três categorias.

Os textos elaborados a partir dos concursos prisionais formam um conjunto que permite indagar, de outros ângulos, as relações entre o dentro e o fora do cárcere, revelando as tensões constitutivas da prática da escrita neste ambiente e apontando para o texto como um objeto privilegiado de disputas e jogos de forças envolvendo os presos e a instituição prisional: ao circularem, estes textos carregam consigo as marcas desta disputa, permitindo aos leitores que se encontram fora do cárcere que conheçam as nuances de uma experiência de aprisionamento. Por outro lado, ao expandirem o local da produção desses escritos presídios outros que não apenas o Carandiru - essas criações específicas voltam a nos fazer pensar a maneira como a sociedade mais ampla percebe o cárcere a partir da marca Carandiru, como foi trabalhado no capítulo um. O imaginário sobre o cárcere é em geral um imaginário sobre o Carandiru, mesmo quando não estamos mais tratando dele. Assim que mesmo enraizados em outras experiências, os textos provenientes de outras prisões, que os concursos nos permitem conhecer, mostram-se, no limite, também como textos do Carandiru.

\footnotetext{
${ }^{70}$ Dentre os autores que não se encontravam presos no Carandiru (Casa de Detenção Flamínio Favero), foram premiados detentos das seguintes unidades prisionais: Penitenciária Feminina (São Paulo, SP), Penitenciária II de São Vicente (São Vicente, SP), Penitenciária da Capital (São Paulo, SP, feminina) e Penitenciária do Estado (São Paulo, SP).
} 


\subsection{LIVROS ESCRITOS A MUITAS MÃOS: MEDIAÇÃO E NEGOCIAÇÃO}

Se nos livros produzidos e publicados individualmente analisados antes foi possível observar a mediação sistemática de sujeitos de algum modo vinculados ao mundo editorial, nos publicados a partir de concursos literários é notória a presença de um número maior de atores, assim como o jogo de forças que se estabelece entre eles. Esses textos nos permitem compreender, assim, os sentidos que a prática da escrita do cárcere assume para outros sujeitos que não apenas o escritor, já que a iniciativa de escrever não parte dele, mas nasce de algum agente externo, seja o editor que propôs o concurso ou o diretor do presídio que elaborou o projeto.

Vale observar que apesar de diversos concursos literários terem sido realizados em presídios na última década ${ }^{71}$, nem todos contaram com a publicação dos textos selecionados. E são as edições que permitem que um público leitor externo ao cárcere conheça o que é produzido no interior da prisão, como venho demonstrando ao longo da tese. Diferentemente dos volumes analisados antes, em que o conteúdo e a forma da escrita foram tomados como elementos centrais da interpretação, o tratamento de publicações resultantes de concursos literários impõe a consideração analítica do artefato livro. Isto porque tais produções coletivas têm lugar a partir de disputas constantes em relação aos sentidos do texto e da escrita no cárcere, que se revelam na estrutura material do livro, por exemplo, nas diversas seções em que sujeitos diferentes - presos e diretores de presídios - tomam a palavra e dissertam sobre a escrita no cárcere, sobre o próprio cárcere ou, ainda, sobre a escrita de um companheiro de cela. Dissensões que se revelam ainda na disposição dos textos e nas ilustrações.

\footnotetext{
${ }^{71}$ A realização de concursos nos presídios aparece como uma ação pautada na ressocialização dos presos, sendo que os concursos artísticos (literário, desenho e teatro) são os mais realizados. Inúmeras iniciativas foram noticiadas nos últimos anos, sem que, no entanto, fossem transformados em livros: em novembro de 2017, a Agência Estadual de Administração do Sistema Penitenciário do Mato Grosso do Sul noticia "Presídio em Corumbá trabalha ressocialização de detentas com concurso de prosa e poesia", disponível em: http://www.agepen.ms.gov.br/presidio-de-corumba-trabalha-ressocializacao-de-detentas-com-concurso-deprosa-e-poesia/; em agosto de 2016, o Portal da Cidade de Poços de Caldas anuncia: "Flipoços realiza concurso literário no presídio de Poços de Caldas", disponível em: https://pocosdecaldas.portaldacidade.com/noticias/cultura/flipocos-realiza-concurso-literario-no-presidio-depocos-de-caldas; em setembro de 2004, o Centro de Mídia Independente noticia o concurso realizado em presídio feminino de São Paulo: "Concurso Literário ZAP no Presídio Feminino de Franco da Rocha provocou emoção", disponível em: https://midiaindependente.org/pt/blue/2004/09/290503.shtml. Acessos em 29/04/2018.
} 
O volume Letras de Liberdade teve sua origem em um concurso literário realizado em presídios paulistas a partir da iniciativa de duas editoras, a Madras e a Letras e Expressões, e foi publicado no ano de 2000. O livro conta com quinze textos premiados, seguidos, todos eles, de um posfácio assinado por alguma personalidade seja do mundo acadêmico, do sistema prisional, do terceiro setor ou do mundo das artes em geral. Todos os textos carregam informações sobre o autor visando apresentá-lo, e um desenho à mão, elaborado por um grupo formado por três presos, identificados em cada texto a partir do nome e do número do prontuário, que servem também como ilustrações. Em Letras de liberdade, o editor aponta, em nota, que foram recebidos 345 textos, a maioria deles de cunho biográfico ou autobiográfico, indicando, segundo suas palavras, uma vontade dos presos e presas de narrarem histórias - as suas ou as de outros.

O livro O Direito do Olhar: Publicar para Replicar, publicado pelo IDDD - Instituto de Defesa do Direito de Defesa - em 2009, possui características bastante diferentes do anterior. Em primeiro lugar, notamos aí a presença mais evidente da fotografia e do desenho. Além disso, o concurso teve como público alvo a população feminina, tendo sido o projeto realizado tanto nas penitenciárias paulistas quanto nos estabelecimentos voltados para as adolescentes em conflito com a lei. Outra característica diferencia este volume do anterior: o concurso que está na origem deste volume não incluiu apenas presas ou adolescentes cumprindo medidas socioeducativas, mas contou com a participação de agentes prisionais e instrutoras dos centros socioeducativos.

É possível dizer que este livro não é somente uma seleção dos projetos premiados, mas é ele mesmo um projeto, já que ao apresentar o concurso, desde sua elaboração aos seus objetivos e resultados, ele visa a sua replicação em outros estados do país, por isso o subtítulo: "Publicar para replicar". Observemos ainda que o concurso em questão incluiu a premiação de desenhos e fotografias, além de entrevistas com as participantes, falas de representantes da sociedade civil e do Estado, assim como um quadro com dados sobre o sistema prisional brasileiro. O livro mostra-se, portanto, como um mapa de certa produção artística nos presídios femininos paulistas e nas instituições de medida socioeducativas ${ }^{72}$.

\footnotetext{
72 Ainda que se tratem de instituições com interesses e missões institucionais bastante diversos - uma editora que é um empresa atuando no mercado, de um lado, e uma instituição do terceiro setor voltada para a defesa do direito de defesa, ancorada em um compromisso com a promoção e a defesa dos direitos humanos - o que se percebe é que ambas voltam-se para a escrita no cárcere como algo que aponta para a ressocialização. Se o IDDD valoriza a prática artística - o que inclui a escrita - como um fazer ancorado na construção de uma certa cidadania, a Madras e Letras e Expressões promovem um concurso literário nas prisões paulistas no intuito de
} 


\subsubsection{Construindo o "sentido literal"}

Letras de Liberdade e O Direito do Olhar são formados a partir da reunião de textos de naturezas e autorias diversas; neles estão presentes vários autores: os presos, os diretores dos presídios, os idealizadores dos concursos, autoridades na área prisional, entre outros. Essa multiplicidade de vozes permite trilhar os caminhos pelos quais se elabora o projeto das publicações em questão e também os sentidos que foram atribuídos a eles pelos sujeitos envolvidos.

O volume Letras da Liberdade é apresentado por meio de três textos: o primeiro deles, assinado pelo editor da WB Editora, Wagner Veneziani Costa; o segundo, pelo então Assessor da Diretoria do Complexo do Carandiru, Paulo Braga; e o último, pelo Diretor da Casa de Detenção de São Paulo à época, Maurício Guarnieri. Não há, nesses textos iniciais, uma explicação clara sobre o intuito que orientou a elaboração do projeto; não é possível saber, por exemplo, onde ele teve início, quem o idealizou ou os motivos que levaram uma editora particular - e não instituições públicas ou do terceiro setor, que apoiaram $O$ direito do olhar, a ser analisado mais adiante - a publicar um livro desse tipo. No entanto, a partir do posicionamento do editor e, posteriormente, dos dois representantes do sistema prisional, é possível compreender que o trabalho da escrita é percebido por eles como uma atividade ressocializadora. Oferecer aos detentos e detentas a possibilidade de escrever - e ter os seus textos publicados - é compreendido como uma prática que possibilita aos presos refletirem sobre suas vidas acidentadas, permitindo também que a instituição conheça os autores por meio desta atividade narrativa. Além disso, com eles, a população exterior ao cárcere pode ter acesso às trajetórias daqueles que "erraram" perante à justiça e à certa visão sobre aquilo que o suposto "erro" poderia representar.

Ao iniciar seu texto com um agradecimento aos presos e presas que participaram do concurso Letras da Liberdade, o editor Wagner Veneziani indica alguns sentidos por ele atribuídos a esse tipo de escrita específica do cárcere:

oferecer aos presos e presas a possibilidade de um retorno à sociedade, ancorados em um certeza acerca da potência da escrita na modificação das pessoas que a ela se voltam. 
A todos, agradecemos sensibilizados pela participação, atitude que denota um claro processo de ressocialização e, mesmo com o sentido de justiça travado na garganta, estes participantes fizeram questão de contar 'histórias' - suas ou de terceiros - para mostrar-nos aquilo que bem sabemos, ou seja, que a semente da criminalidade encontra-se nas desigualdades sociais (AUTORES DIVERSOS, 2000, p.9).

O editor nos oferece, aí, duas visões: uma sobre a escrita na prisão e outra sobre a criminalidade; a produção textual denotaria um processo de ressocialização, enquanto a criminalidade teria suas raízes nas desigualdades sociais. Ao abrir o livro com essas duas afirmações, Veneziani oferece ao leitor a "correta" interpretação sobre a atividade de escrita no cárcere: os autores selecionados, e também aqueles que não o foram mas que escreveram textos para o concurso, deveriam ser compreendidos como em processo de ressocialização a escrita o comprovaria. O sentido atribuído ao texto desses autores informa que tais presos, apesar de terem "errado", adquiriram, com a produção textual, uma consciência dos erros e o desejo de mudança para retornarem ao convívio da sociedade modificados de forma positiva. Quer dizer, ao atribuir sentidos específicos à produção textual do cárcere, o editor também produz a chave para a interpretação e a leitura dos textos em questão.

A produção textual prisional, ainda segundo as palavras do editor, carrega uma "verdade" que deve ser levada em conta: a de que "a semente da criminalidade encontra-se nas desigualdades sociais". Essa "verdade", no entanto, não está presente apenas nos textos, já que ela é de conhecimento geral, "bem sabemos", ele diz. Os textos, por sua vez, trariam à tona essa verdade. Ao afirmar a "verdade" do texto, verdade que extrapola a própria escrita, o editor realiza uma operação que ao discorrer sobre a atividade da escrita e da leitura, Certeau (2013) chama de "produção do sentido literal". Para este autor, qualquer texto permite uma pluralidade de leituras. No entanto, quando os idealizadores do livro oferecem ao leitor um sentido literal, isto é, uma "interpretação correta", é possível perceber um jogo de forças em questão, em que o texto passa a esconder um segredo, e apenas "profissionais ou clérigos socialmente autorizados", ou seja, os especialistas da área, poderiam encontrar seu verdadeiro sentido; "deste ponto de vista, o sentido 'literal' é o sinal de um efeito de poder social, o de uma elite" (CERTEAU, 2013, p.243). O texto seria, portanto, ele mesmo, uma arma cultural, não daqueles que o escrevem, mas de uma elite que determina o seu sentido literal, buscando determinar, justamente, a leitura "correta".

Em outras palavras, os textos produzidos no interior dos concursos prisionais possuem sentidos diversos, já que foram elaborados por presos em situações diferentes, no 
entanto, os editores das publicações ou os diretores dos presídios em questão procuram determinar, de antemão, esse sentido ao leitor, oferecendo a ele a "leitura correta", o que excluiria a possibilidade de outros tipos de leitura e interpretação.

A atitude dos editores de ditarem o sentido da leitura dos textos prisionais pode ser encontrada nos outros textos que compõem a introdução de Letras da Liberdade. O potencial de ressocialização da tarefa da escrita também é destacado pelos representantes do Sistema Prisional que prefaciam o livro. Paulo Braga, Assessor da Diretoria do Carandiru à época, ao valorizar o projeto, afirma:

Assim, ao levar a ideia da realização do primeiro livro escrito por reeducandos no Complexo Carandiru e obter de imediato a aceitação da proposta, foi dado mais um passo ao retorno à sociedade daquele que um dia errou e merece da própria sociedade a chance de reabilitação (AUTORES DIVERSOS, 2000, p.11).

A escrita, portanto, seria uma demonstração, por parte do "reeducando", de que ele merece uma nova chance da sociedade, podendo voltar a conviver com os demais a partir de uma noção de reabilitação. $\mathrm{O}$ texto seria um artefato produzido pelo preso que fala sobre ele mesmo, a seu favor, a partir da ideia de ressocialização, atestando que ele errou, que tem consciência disso e, por isso mesmo, merece uma segunda chance.

O texto de Maurício Guarnieri, então Diretor da Casa de Detenção, atribui outros sentidos à escrita prisional, ainda que o primeiro deles seja pautado, mais uma vez, na ideia de ressocialização:

Aceitei participar deste projeto porque o seu objetivo é buscar a ressocialização daqueles que se encontram segregados dentro das penitenciárias. Com esta atitude de relatar suas vidas, impressões, os sentenciados adquirem maior responsabilidade, amparados de uma forma concreta, buscando um lugar dentro da própria sociedade que os segregou por terem cometido algum delito (AUTORES DIVERSOS, 2000, p.13).

O trecho de Guarnieri mostra que a sua compreensão da escrita no cárcere não se concentra no seu produto - o texto - mas em seus efeitos, que são percebidos nos corpos e condutas dos presos. Enquanto o editor mencionado antes detém-se sobre o texto, objeto 
que carrega uma "verdade", o Diretor do presídio parece se importar pouco com o ele, preocupando-se com os efeitos da escrita para o processo de ressocialização. Diferença de olhar que é condizente com o lugar social ocupado por cada um deles: um editor que valoriza o texto produzido e um diretor de presídio que estima a ação do sujeito encarcerado.

Mas para Guarnieri, a escrita no cárcere assume outras funções, que não apenas a de ressocialização. Ao falar sobre o conteúdo do livro que apresenta, ele afirma que "Os relatos que o mundo 'além muralhas' tomará ciência servirá para que se conheça um pouco desse universo desconhecido"; há muito "folclore" em torno do dia a dia das prisões, continua ele, “comenta-se, distorcidamente, que o preso não faz nada o dia todo, e não há qualquer tentativa de ressocialização". Os textos dos detentos "servem", então, como uma janela a partir da qual os homens que não conhecem o cotidiano prisional podem olhar para ele e conhecê-lo um pouco melhor. Isso não significa "que a prisão seja uma maravilha. Ao contrário, é muito dura, dita normas próprias"; no entanto, ele acredita que "com esses relatos, os jovens ficarão alertas e saberão aproveitar a liberdade, algo que não se pode dimensionar até que seja perdido, e, portanto, devem respeitar seus limites" (AUTORES DIVERSOS, 2000, p.13-14).

É possível notar a operação de construção de um “sentido literal” não apenas nos prefácios que abrem o livro, mas também na sua concepção: todos os quinze textos são precedidos por uma imagem (desenho à lápis produzido por um trio de detentos); por informações do prontuário de cada um dos autores e por uma fotografia, em formato $3 \times 4$, do escritor. Como posfácio, cada uma das publicações é comentada por um convidado que possui algum tipo de experiência seja com a escrita, seja com o universo prisional. Todos estes elementos atuam no sentido de criar um "sentido literal" e orientar a leitura que se fará do texto, da escrita e do universo prisional.

Assim como o projeto Letras de Liberdade inclui textos que não foram produzidos por presos ou presas, o mesmo pode ser percebido em O Direito de Olhar. Os organizadores incluíram ao final do volume uma seção onde as próprias participantes do concurso comentam, a partir de entrevistas realizadas com elas, a atuação no projeto, relatando a maneira como se viram transformadas por meio do fazer artístico ali proposto. No entanto, no momento em que as autoras discursam sobre o processo da escrita ou da fotografia e desenho, elas o fazem em função de um direcionamento claro: da elaboração de perguntas feitas por aqueles que assinam o projeto, o que direciona o olhar das autoras ao mesmo tempo em que determina os sentidos que elas mesmas atribuem à escrita. 
Em Letras de Liberdade, alguns textos e outros tipos de materiais circundam o que seria o texto principal, sendo que cada um deles possui um estrutura específica que nos permite compreender a maneira como o "sentido literal" vai sendo construído a várias mãos. O primeiro material a acompanhar o texto é um desenho, produzido por outro preso, que funciona como ilustração, na qual consta o nome do ilustrador e o número do seu prontuário (que determina que ele é, também, um preso). Em seguida, em duas colunas vê-se a fotografia do autor do texto premiado e as informações de seu prontuário (diferente do ilustrador, que é determinado apenas pelo número, o autor do texto é caracterizado a partir de diversas informações presentes no prontuário). $\mathrm{Na}$ página seguinte, tem-se o texto premiado e, em seguida, um posfácio, assinado por algum personagem relevante no cenário literário ou dos direitos humanos, comentando-o.

Cada um desses fragmentos (ilustração, fotografia, informações do prontuário e posfácio) possui uma autoria diferente, mas o que os liga é o fato de estarem se referindo ao texto principal, ou seja, o objeto do concurso que, uma vez selecionado, foi publicado. Tal estrutura indica que, do ponto de vista dos elaboradores destes concursos, a escrita do detento, sozinha, não produziria seu "sentido literal"; é preciso, assim, orientar o leitor, oferecendo a ele a leitura de outros sujeitos que possuiriam o privilégio da interpretação, tanto do texto premiado quanto da própria prisão. O que significa que ler este texto é ler em conjunto, é lê-lo juntamente com o editor ou mediador, com o outro preso que o interpreta e elabora um desenho, com o agente prisional, quando este oferece os dados cadastrais dos autores; é lê-lo também com a personalidade que o relaciona com o cenário de crise social, e ainda, lê-lo com o próprio autor, quando este o interpreta a partir da entrevista realizada.

Há assim um conjunto de elementos que antecede o texto premiado, formado por textos e imagens que identificam os autores, e em cada um dos volumes analisados, vale observar, esta identificação é formulada de uma maneira particular. Em O Direito do Olhar, o nome das autoras é acompanhado da informação sobre sua colocação no concurso (se premiada, vencedora, menção honrosa etc.) e do local onde elas cumprem pena, com o nome da penitenciária ou instituição de medida sócio educativa. No livro Letras da Liberdade, por sua vez, os autores são identificados através das informações presentes no prontuário: nome, cor dos olhos, cor do cabelo, sinais particulares, estado civil, data de nascimento, naturalidade, grau de instrução, profissão, vulgo, unidade prisional, data de entrada, prontuário (número de matrícula no sistema prisional), indiciação e condenação. Todos esses dados estão presentes nos elementos pré-textuais e não se repetem em outro lugar. O nome 
do autor, por exemplo, não é sinalizado abaixo do título do texto, o que seria uma forma mais convencional de identificação de autoria, mas é indicado apenas nesta seção onde o nome é apresentado ao lado de outras características, como o número do prontuário ou a cor dos cabelos.

A forma de identificação dos autores dos textos premiados com base nas informações contidas em seus prontuários elucida, mais uma vez, a presença institucional (e as tensões resultantes desta presença) na elaboração dos volumes resultantes de concursos prisionais. Quem nomeia e qualifica o preso escritor é a instituição, que o faz desde documentos típicos da burocracia prisional. Ao autor é destinado apenas o espaço do próprio texto, local onde poderá confirmar - e por vezes, contrariar - as informações sobre si que lhe foram impostas pelo prontuário.

Ao analisar a produção de documentos de identificação prisional em Bomana, uma prisão de segurança máxima em Papua Nova Guiné, Reed (2006), a partir do exame de outros materiais, descreve um processo semelhante, em que é possível perceber uma tensão entre a instituição prisional - produtora dos documentos - e os presos - sujeitos que recebem uma identificação por meio das informações que lhes são imputadas. Em Bomana, Reed aponta para uma certa produção de documentos que têm como resultado a identificação dos sujeitos presos, entre eles, a warrant cover, algo próximo ao prontuário das prisões brasileiras, e a autograph, que traduzido livremente, seria o autógrafo. Na warrant cover há uma série de dados que devem ser preenchidos pelos funcionários do presídio, trazendo à tona informações sobre o preso, tais como nome, idade, religião, língua, ocupação, mas também informações sobre seu processo criminal, transferências entre presídios e detenções anteriores. A autograph, por sua vez, é preenchida pelo próprio detento (e talvez aqui possamos compreender o sentido de "autógrafo", ou "auto grafia", uma escrita sobre si, em um sentido próximo ao da autobiografia sem, no entanto, ser formulada de forma narrativa), e traz dados que apontam principalmente para aquilo que está ausente na prisão: para além do nome e data de nascimento, também presentes na warrant cover, o documento elenca comida e bebida favoritas, melhores amigos, pior medo, desejo para o futuro, gangue a que pertence, mulheres presentes em sua vida etc.

Estes dois tipos de documentos revelam tecnologias semelhantes, apesar de expressarem táticas opostas. A warrant cover é de responsabilidade dos agentes prisionais, e garantem um conhecimento acerca dos homens aprisionados, a partir de dados objetivos. A autograph, por sua vez, caminha na direção contrária à objetificação realizada pelo primeiro 
documento, apontando para relações estabelecidas antes da prisão e para aquilo que o detento deseja construir para além dela. Para Reed, o primeiro tipo de documento é resultado de relações hegemônicas dentro da instituição prisional, sendo que a tecnologia dos documentos é também responsável pelos processos de subjetivação dos sujeitos aprisionados. O segundo tipo poderia ser analisado como uma forma de resistência, em que os presos, ao se auto definirem a partir de critérios subjetivos e exteriores ao presídio, construiriam outro tipo de subjetividade que não aquele pretendido pelos processos institucionais.

Ao colocar lado a lado warrant cover e autograph, a leitura de Reed mostra-se bastante sugestiva para a análise que proponho em relação à elaboração dos livros resultantes dos concursos prisionais. Em Letras de Liberdade, as informações sobre o autor, na forma dos dados do prontuário (e localizadas próximas ao texto por ele escrito) são elaboradas pela instituição prisional, tendo como base os documentos institucionais. Ainda que a narrativa premiada não possa ser equiparada à autograph do presídio Bomana, ela é um texto produzido pelo preso que versa, entre várias coisas, sobre sua trajetória, desejos, sonhos, pessoas próximas ou queridas etc. Os dois materiais escritos (o escrito pelo preso e aquele composto pelos dados do prontuário), colocados lado a lado, revelam modos distintos de identificar o sujeito: seja pela objetificação (informações do prontuário); seja pela construção de uma subjetividade baseada em experiências exteriores à vida na prisão (a narrativa), o que nos permite vislumbrar, mais uma vez, as tensões presentes na elaboração destes livros, em que sujeitos diferentes (a instituição prisional e o preso) constroem sentidos diversos para o texto publicado, estabelecendo, a partir dele, noções específicas sobre o sujeito que escreve no cárcere. 


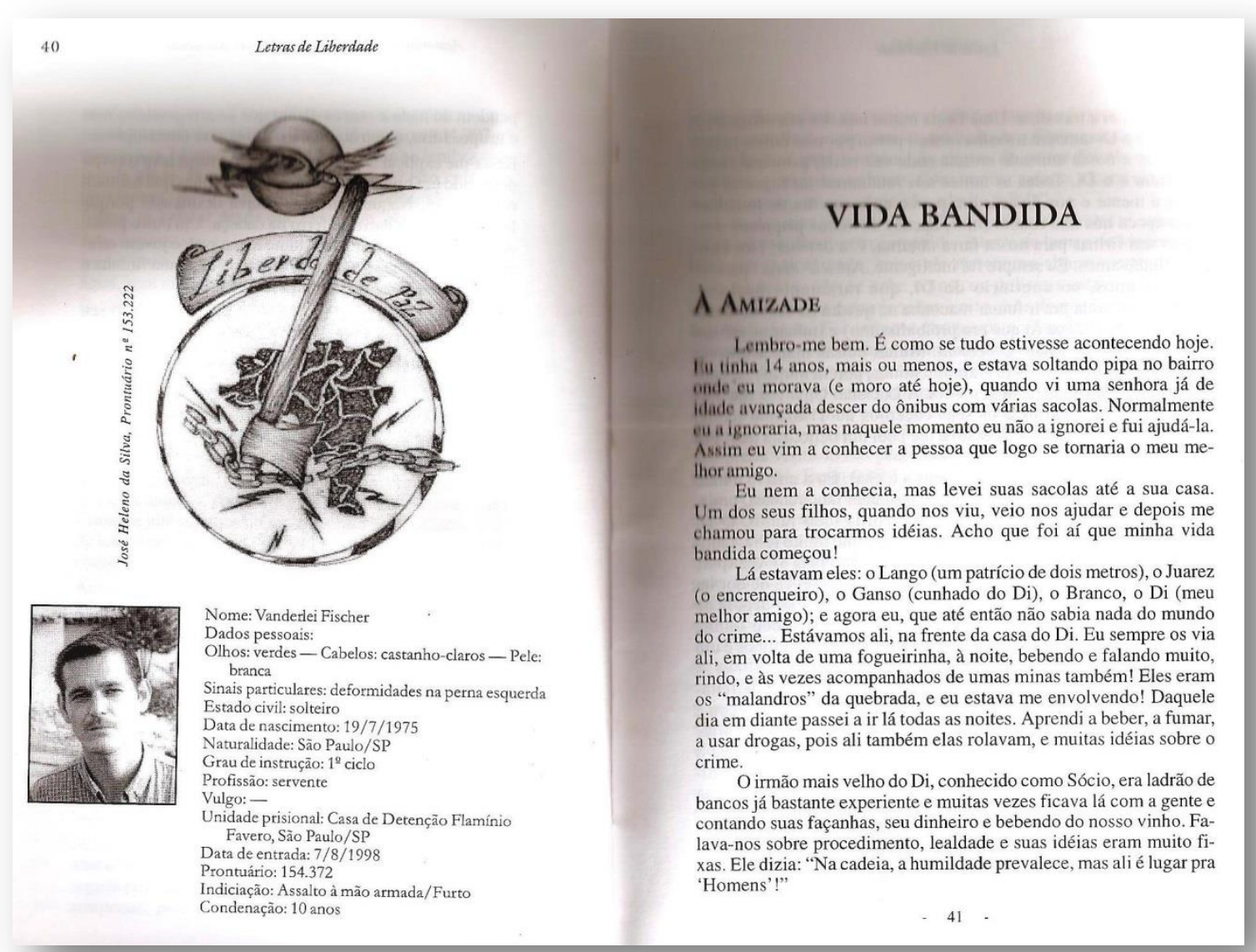

Figura 3.1: Autores Diversos, Letras de Liberdade, p.40-41.

Muitos dos trabalhos acadêmicos produzidos sobre as prisões no Brasil apontam para os processos de construção de subjetividades que se dão no seu interior, apesar de um desejo institucional de anulação do eu (PADOVANI, 2010; GODÓI, 2010; LAGO, 2014), literatura que contraria, portanto, a tese de Goffman (2005) que vê o processo de inclusão do indivíduo na instituição prisional como algo que aniquila a subjetividade. O que se percebe, mostram os estudos recentes, é um processo positivo de construção de uma identidade específica, em que um novo sujeito emerge dentro de um padrão previamente determinado pela instituição.

Ao incluir como elementos pré-textuais dados dos prontuários dos presos, os responsáveis pela elaboração de Letras de Liberdade oferecem uma leitura institucional (prisional ou jurídica) sobre os autores: são essas informações que orientam o leitor que, antes de ter acesso ao texto, recebe uma retrato do seu autor, com a ajuda da imagem 
fotográfica e de informações sucintas sobre sua condição. Assim que não é o autor que escolhe a sua identidade, já que, em todos os textos publicados em Letras de Liberdade, as informações do prontuário prisional estão presentes, na íntegra. Em alguns casos, a fotografia do autor aparece como "não autorizada", sugerindo, portanto, que os autores tiveram a possibilidade de escolha em relação às imagens, mas não em relação aos dados institucionais divulgados.

A impossibilidade de eleger as informações sobre si que chegam ao público também se verifica nos autores anteriormente analisados, já que eles, apesar de alçados à categoria de escritores, não podem escapar à sua biografia ou ao seu prontuário: André Du Rap lembra que irá carregar para sempre a sua "carteirinha de bandido"; Mendes afirma que não consegue publicar nada que não seja relacionado à sua vida na prisão; Rodrigues também é reconhecido como um homem preso que passou a escrever na prisão, e assim é caracterizado na orelha de seu livro; Ramos é identificado como o médico famoso que escreveu todos os seus livros no interior do presídio.

Se a estrutura de Letras de Liberdade, com os elementos de apresentação dos autores e a forma de disposição deles ao longo do livro, é definida pelos elaboradores do concurso, não restando aos autores dos textos premiados a possibilidade de definirem a si mesmos, a eles é oferecido o espaço para a criação textual; é nesse espaço, então, que parecem gozar de liberdade para versarem sobre si, sobre outros, sobre sua trajetória, ou sobre o sistema prisional. Apesar de o livro estar construído sobre os textos laureados, percebe-se que o espaço cedido ao preso para falar de si ou de outrem é restrito, já que ele não pode nada que escape deste espaço, sendo vetada a ele, inclusive, a possibilidade de se definir e se apresentar. A arquitetura do livro revela, assim, as tensões entre instituição prisional (juntamente com os elaboradores do concurso - editores e diretores dos presídios) e aqueles que escrevem.

Os textos premiados encontram-se antecedidos também por uma ilustração feita à mão e por um retrato do preso. Todas as ilustrações foram elaboradas por três presos, citados nos agradecimentos no início do livro: Antônio Rogério Pinheiro, José Heleno da Silva e Magno Alves Motta (os nomes seguidos de seus respectivos números dos prontuários). Em relação às fotografias, não há legenda ou menção à autoria e, em apenas um caso, o espaço destinado à fotografia do autor do texto está em branco acompanhada de: "Não autorizada". 


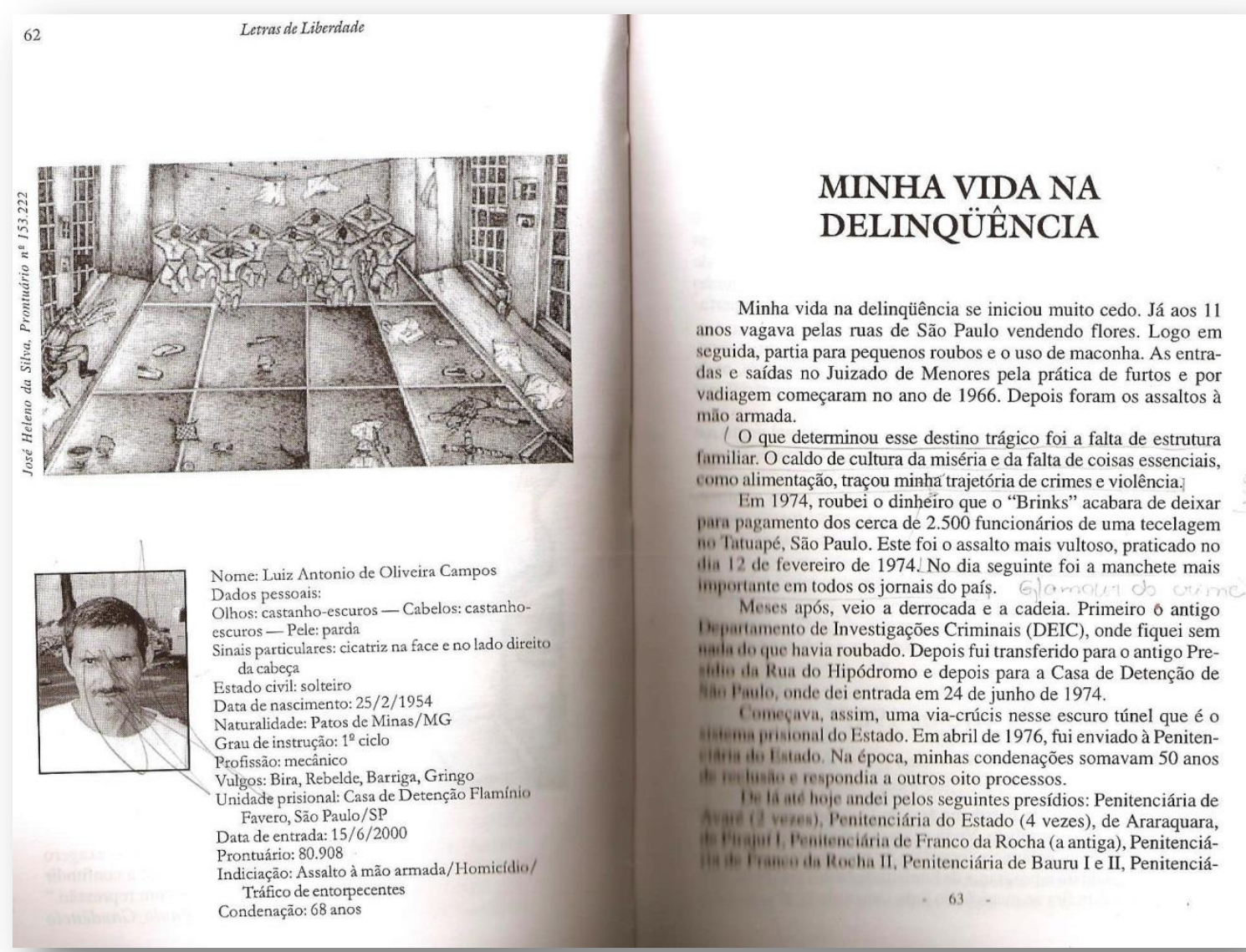

Figura 3.2: Autores Diversos, Letras de Liberdade, p. 62-63. 


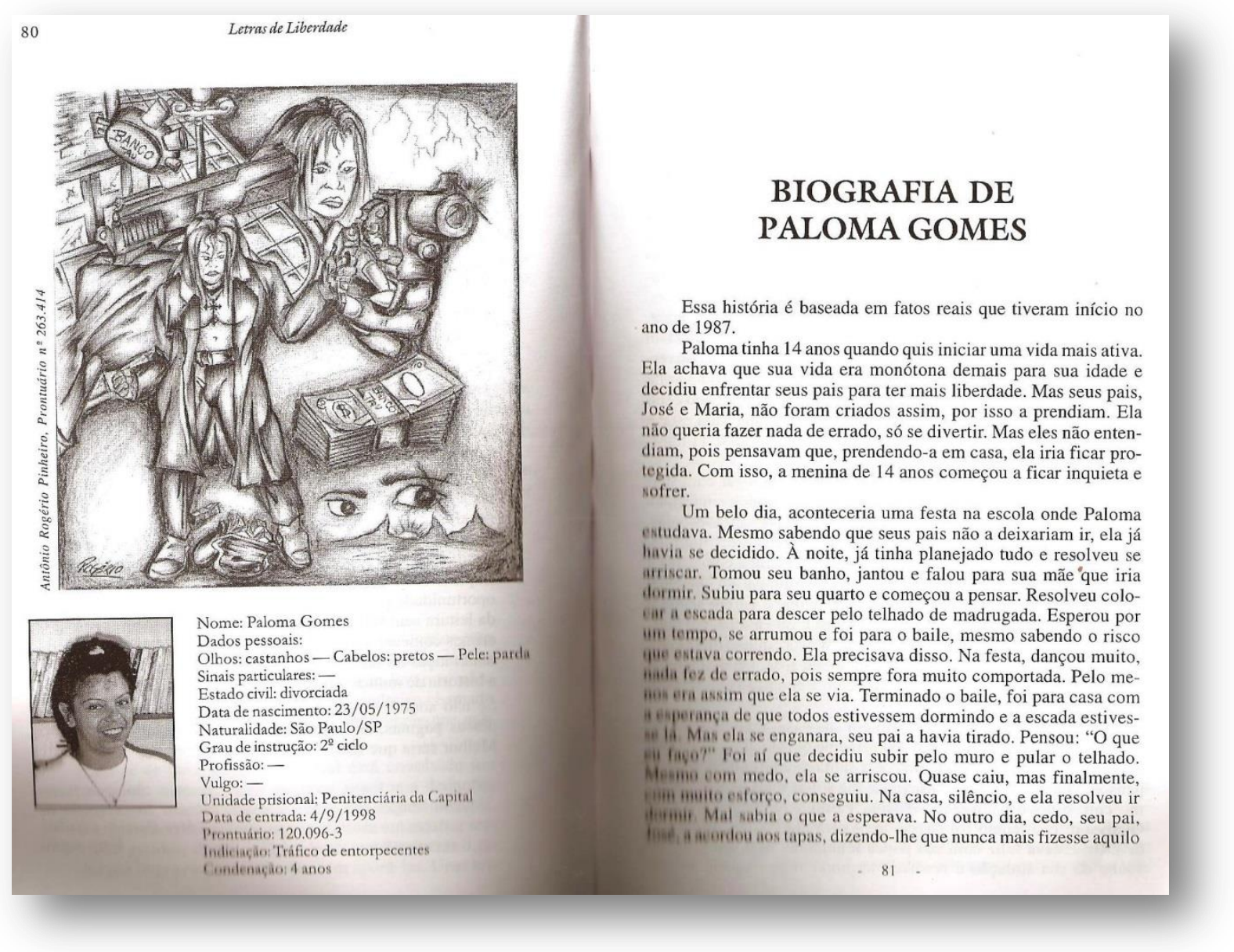

Figura 3.3: Autores Diversos, Letras de Liberdade, p. 80-81.

As ilustrações podem ser vistas como interpretações dos textos realizadas por sujeitos submetidos às mesmas condições do autor: eles também se encontram presos. Nelas, os desenhistas procuram representar aquilo que foi narrado no texto, o que faz com que muitas delas se aproximem, já que o conteúdo dos textos é bastante semelhante entre si: por exemplo, é recorrente, ao longo do livro, a representação da prisão e de eventos que ocorreram ali dentro, como rebeliões ou a invasão de policiais; há também uma grande presença de símbolos que representam a liberdade; algumas delas constroem o momento do crime de forma a exaltar a figura do assaltante, o que permite uma ampliação dos sentidos do texto, o que pode ser visto em algumas das imagens reproduzidas acima.

Tais imagens também operam no sentido da construção do "sentido literal" do texto; assim como a reprodução de alguns dos dados da ficha de prontuário do autor, os desenhos 
elaborados por outros presos auxiliam a produzir efeitos de verdade sobre ele. O que nos leva a afirmar que dentre as pessoas escolhidas pelos elaboradores do concurso para produzir interpretações sobre os textos encontram-se também outros presos, os colegas de cela do autor que, por se encontrarem dentro do presídio, teriam outro tipo de autoridade para interpretar, a partir da produção de um desenho, o que foi escrito.

A valorização da experiência prisional como a única legítima para falar sobre a própria prisão encontra-se presente em outros textos do cárcere, como foi observado a partir da leitura do diário de Rodrigues, em que é recorrente a ideia de que só quem passou pela experiência do cárcere poderia narrá-la. Assim que faz sentido ter uma imagem de outro preso como o primeiro elemento pré-textual exposto: a ilustração, como pode ser visto nas reproduções acima, antecede até mesmo o nome do autor do texto premiado. Os três presos que elaboram os desenhos comporiam, então, o primeiro corpo de intérpretes, trazendo ao leitor, que não conhece o cárcere, algumas imagens que podem ser tomadas como indicações daquilo que está sendo dito no texto.

Vejamos um exemplo. Na figura 3.3 estão reproduzidas as páginas 80 e 81 do livro Letras de Liberdade, onde se encontram a ilustração, o retrato da autora, as informações do seu prontuário e a primeira página de seu texto, "Biografia de Paloma Gomes". A ilustração, assinada por Antônio Rogério Pinheiro, constrói a imagem de uma mulher forte, com arma em punho, ao lado de uma grande quantia de dinheiro; alocando na imagem, ainda, a placa de um banco, o que indicaria a realização de assaltos a instituições financeiras; há, por fim, a imagem de um olhar, que parece, de certa forma, apreensivo ou triste. $O$ texto volta-se para a trajetória de vida de Paloma, narrada em terceira pessoa, estratégia que permite à autora se afastar da sua própria história, ainda que ela inicie afirmando o seu caráter documental: "Esta história é baseada em fatos reais que tiveram lugar em 1987” (AUTORES DIVERSOS, 2000, P.81). A história de Paloma é composta com vistas a construir um sentido para sua prisão; para tanto, a autora traz elementos de uma adolescência conturbada, em que conflitos com os pais e o envolvimento com pessoas que já praticavam alguns tipos de crime é uma constante. A segunda gravidez precoce, a expulsão de casa e o momento em que passa a viver com o namorado aparecem como o momento de virada na história: quando ele planeja um assalto a banco, do qual ela participa, e os dois terminam presos. Ao final da narrativa, a autora afirma que foi na prisão que Paloma encontrou seu "verdadeiro amor", um amor homossexual. Ao longo de toda a história, a narradora do texto elabora sentidos que 
justifiquem as ações da personagem, como as tensões presentes em casa e as brigas constantes com a mãe e o relacionamento com homens que a levaram a praticar atos ilícitos.

Nessa história não se dá uma exaltação da vida no crime, o que se observa, ainda que de forma velada, em outros textos do mesmo volume. O momento do assalto ao banco não constitui o ápice da trajetória de Paloma, e nem serve como fundamento para a elaboração da identidade forjada pela autora do texto. A ilustração, no entanto, parece destacar esse momento, fruto da interpretação que o ilustrador, Antônio Rogério, faz da história desta autora; a interpretação construída a partir de um compartilhamento de experiências e de sentidos. Antônio Rogério, assim como Paloma Gomes, possui um número de prontuário, o que coloca a ambos num espaço delimitado pelas grades. E é a este "igual" a quem é dada a primeira tarefa de interpretação e construção do "sentido literal" do texto que chega ao leitor. Apesar deste compartilhamento - ambos se encontram do lado de trás das grades Antônio Rogério parece interpretar não apenas o texto de Paloma, mas antes, a própria prisão e sua experiência ali. Enquanto Paloma elabora seu texto de forma a construir uma trajetória repleta de erros sobre os quais ela se arrepende exatamente por se encontrar presa, o desenhista, por sua vez, elabora um outro sentido para a trajetória de Paloma, valorizando sua coragem e ousadia, mesmo que estes atributos a tenham levado a carregar olhos tristes ou apreensivos. Percebe-se, assim, que os desenhos elaborados pelos presos também são, eles mesmos, interpretações sobre o cárcere e a experiência prisional, que extrapolam os textos que buscam, a primeira vista, ilustrar.

Os retratos, apesar de apresentarem padrão retangular, assemelhando-se àquele utilizado na elaboração de documentos oficiais $(3 \times 4)$, afastam-se desse formato ao incorporarem cenários de fundo e ao permitirem aos retratados que sorriam para a câmera fotográfica. Assim que a imagem fotográfica parece apontar em outro sentido: o rosto, este local sagrado da identidade humana ocidental (BRETON, 2009), está representado de forma ligeiramente distinta da forma convencional dos documentos. Sorridente, Paloma se humaniza. As fotografias e os dados do prontuário indicam uma ambivalência em relação à presença dos autores no livro. Eles são, antes de mais nada e acima de tudo, presos, sujeitos institucionalizados que fazem parte de uma comunidade, não sendo reconhecidos por suas individualidades, mas por aquilo que os iguala: um número da matrícula. Mas eles também são indivíduos, com um rosto e uma identidade forjados a partir de outras relações construídas e estabelecidas fora do cárcere. Se os dados do prontuário afastam o autor do de seu possível leitor (pensando, com Palmeira, nos leitores como os "homens de bem" em 
oposição aos presos, os "homens do crime"), os retratos os aproximam, pois que permitem vislumbrar um sujeito com identidades, relações e afetos.

Desenho, fotografia e dados do prontuário precedem o texto, configurando o que aqui estamos denominando de elementos pré-textuais. Ao lado deles, encontra-se um posfácio, em que alguém com reconhecimento fora dos círculos prisionais também comenta o texto. Nestes, a tônica é sempre a valorização daquele que escreve, apontando para a sua capacidade de pensar sobre a realidade prisional. Invariavelmente, os posfácios tocam na questão da injustiça e da capacidade regeneradora de um projeto como Letras da liberdade.

As muitas camadas de produção e interpretação dos textos que integram o volume Letras de Liberdade apontam para as diversas trilhas que precisam ser construídas para então serem percorridas no trânsito entre o interior e o exterior do cárcere. Antes de circular por espaços mais amplos, o texto do autor preso deve ser interpretado por um grupo de especialistas, que informariam o leitor sobre a leitura correta, o que revela que os trânsitos que a prática da escrita permite não são realizados sem mediações e controles. As muitas camadas de produção e interpretação também lançam luz sobre a potência dos textos produzidos no, e a partir, do cárcere. Se, por um lado, eles precisam ser mediados para que saiam da prisão, por outro, precisam ser interpretados pelos “clérigos autorizados" para que não sejam completamente incendiários, como os poemas produzidos pelos presos de Guantânamo, censurados pelo Departamento de Defesa americano e analisados por Butler $(2015)^{73}$. A necessidade de interpretação revela o poder político desses textos ao trazerem para fora do cárcere o que se supunha bem escondido por um aparelho de vigilância e disciplinas.

No volume $O$ Direito do Olhar também é possível perceber a presença de outros textos - e de imagens - que buscam produzir um efeito de interpretação semelhante. Mas nesse livro em especial, os textos selecionados não são acompanhados por uma imagem, já que o concurso estipulou desenhos e fotografias como categorias de premiação distintas. Assim que não há uma ligação particular entre os textos e as imagens publicadas. No entanto, na seção onde contam as entrevistas com as autoras premiadas, observa-se a presença de algumas fotografias. Em uma delas, na qual a autora Verônica Espíndula Vaz, menção

\footnotetext{
${ }^{73}$ Butler (2015) debruça-se sobre os poemas produzidos pelos presos de Guantânamo, publicados no livro Poems from Guantanamo, formado por 22 poemas que passaram pela censura do Departamento de Defesa americano. Os demais poemas, censurados, representariam, segundo o Pentágono, um “'grande risco' para a segurança nacional em razão de seu 'conteúdo e formato"' (BUTLER, 2015, p.88). A autora procura compreender, então, o que, nesses poemas, há de tão incendiário, que faria com que o governo americano rejeitasse sua circulação para fora da prisão.
} 
honrosa em literatura, é indagada sobre o seu processo criativo, vemos uma fotografia que visa reproduzir o texto original: a autora toma às mãos o próprio texto e o lê, mostrando uma dupla ação, a de escrever e a de ler, e as relações entre elas.

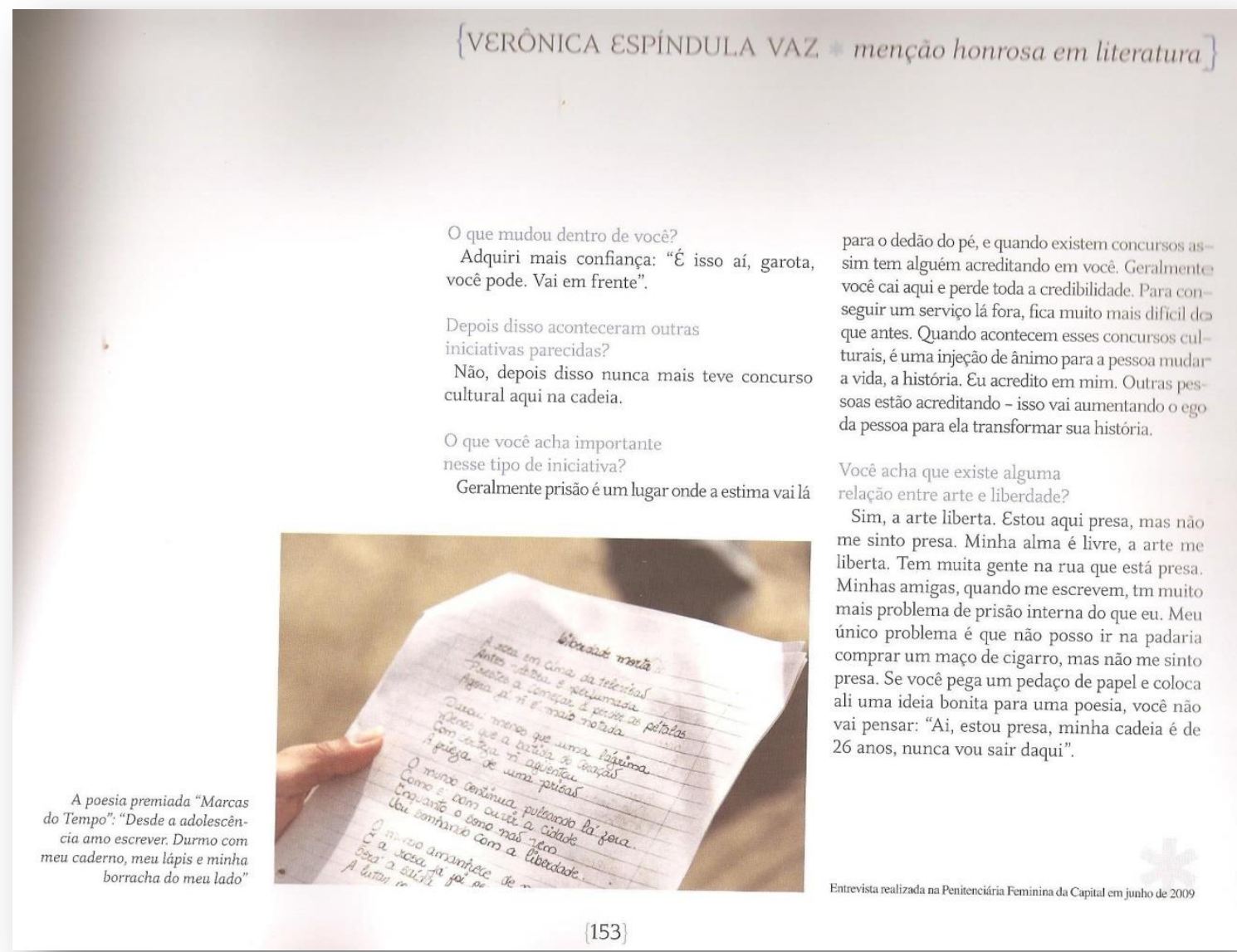

Figura 3.4: IDDD, O Direito do Olhar, 2009, p.153.

Se no volume Letras de Liberdade o retrato do autor atestava a existência de um sujeito a quem é atribuída a autoria do texto, no livro O Direito do Olhar a fotografia também constrói esse efeito de verdade quando traz, por exemplo uma imagem não da autora, mas do gesto e da prática de leitura, realizada pela autora do texto (Figura 3.4). A figura seguinte (3.5) traz outra imagem, que também acompanha, no livro, a entrevista feita com a autora, mostrandoa ao lado do seu texto, impresso em um quadro de dimensões maiores que uma folha e 
fixado na parede, quando da exposição dos trabalhos premiados. Nos dois casos, o texto se converte em imagens com as quais as autoras estabelecem relações de tipo diverso: na primeira, Verônica percorre as frases que ela mesma compôs, o que associa as práticas de escrita e leitura; na segunda, Beatriz (Figura 3.5) mira o texto escrito, assinado por ela, como se ele fosse efetivamente uma imagem, algo monumentalizada em função da premiação. Estamos aí diante de dois lugares comuns da convenção imagética.

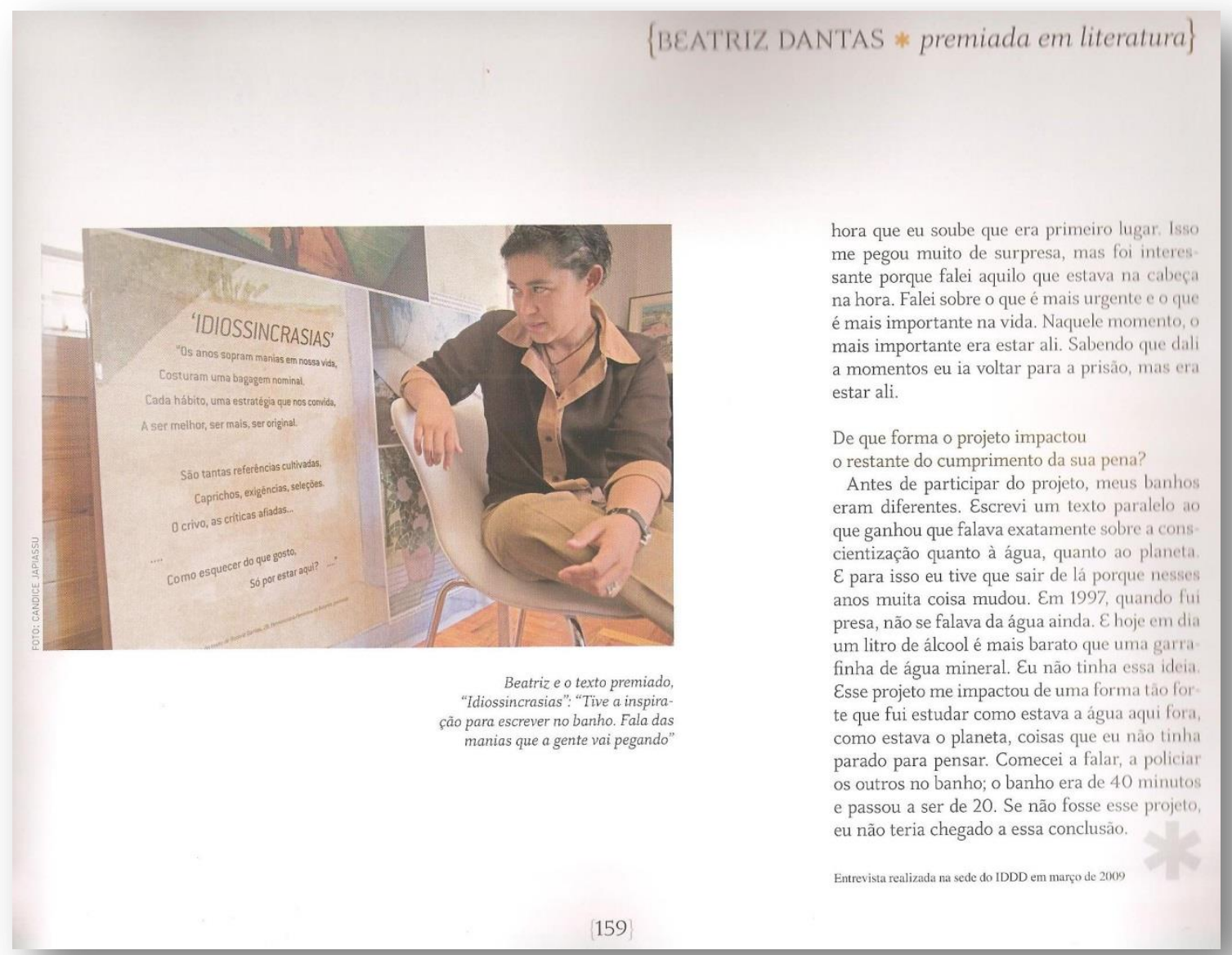

Figura 3.5: IDDD, O Direito do Olhar, 2009, p.159.

Não esqueçamos que este texto faz parte de um conjunto constituído para a apreciação de um público especializado, voltado tanto para a arte quanto para a literatura. A exposição das obras, junto com a premiação, foi realizada no Instituto Tomie Ohtake, lugar que abriga exposições artísticas na zona oeste da cidade de São Paulo. Se algumas presas não 
obtiveram a liberação das instituições para participarem de tal premiação, mesmo ausentes, estiveram presentes por meio de seus textos, desenhos ou fotografias, o que não foi o caso de Beatriz, que estava no Instituto e a fotografia capta o momento em que ela olha o texto, encarando a si mesma em um momento de relativa liberdade. Liberdade do texto e também do corpo, que sai da prisão e transita pela cidade. Apesar do escrito de Beatriz apontar para paisagens da prisão, é fora dela que ele se encontra enquanto artefato; o mesmo lugar onde se encontra a sua autora, no momento em que olha para ele na imagem, que aponta para uma liberdade que é o tempo todo aludida pelos textos do cárcere.

Ilustrações, fotografias, entrevistas, informações de prontuário são elementos que informam o leitor sobre a maneira como os textos dos presos devem ser lidos e interpretados. Cada um destes elementos carrega consigo o olhar da instituição que promove o concurso e que busca determinar a maneira como o texto do preso deve ser compreendido. Em outras palavras: o preso, quando se propõe a escrever para os concursos literários, se depara com uma estrutura pronta, a qual deve se adequar, restando a ele o espaço delimitado pelo texto por ele escrito. E é nesse espaço, então, que ele constrói os sentidos para a escrita e também para sua trajetória, como veremos a seguir.

\subsection{FALAR DE SI: INFÂNCIA, CRIMINALIDADE, ADEQUAÇÃO E RESISTÊNCIA}

Muitos dos textos produzidos a partir dos concursos literários elaboram a memória a partir de um ponto de partida comum: a infância. Apesar de este ser um lugar bastante presente nas biografias e autobiografias (o que vimos no caso de Luiz Alberto Mendes), funcionando como um lugar de apoio para o início de uma trajetória, o que se percebe nos textos dos volumes Letras de Liberdade e O Direito do Olhar é a infância como um momento de inocência em contraponto a uma adolescência e juventude em que a criminalidade se mostra de alguma forma presente. A infância seria o momento da pureza, em que o personagem ainda não se corrompeu, e nesse sentido alguns elementos são valorizados: a família e a honestidade atribuída aos pais, principalmente na valorização de uma ética do trabalho. A 
infância em meio à pobreza seria marcada por dificuldades e pela luta da família por uma vida "decente".

Quando criança, tive uma vida normal, com pai, mãe e um irmão cinco anos mais velho. Como uma criança normal, estudava em uma escola estadual perto de casa. [...] Nesta época, nossos pais tinham, financeiramente, uma vida razoável. [...] Vivíamos humildemente, numa casa no bairro da Vila Matilde, zona leste de São Paulo. Lá, fomos criados honestamente. Mamãe sempre trabalhou para ajudar, era fotógrafa e cobradora de ônibus. Papai, professor de capoeira e motorista (Claudelaine da Silva, A Diferença da Vida, in Letras da Liberdade, 2000, p.23).

Quando morava com meu pai, me preocupava muito com meu futuro, mal brincava, ainda criança era muito inocente, observava os menores detalhes que via no dia a dia. Me lembro quando o meu pai me levava para a escolinha, muito contente, eu ia sorrindo e de mãos dadas com ele, e todo dia a mesmice, mas eu era feliz em ver que a minha família era feliz com a minha felicidade (F.P.A.O ${ }^{74}$., Lembranças que trago no pensamento, in O Direito do Olhar, 2009, p. 78).

Os dois excertos acima ilustram a maneira como a infância é retratada nestes textos de forma idealizada, e, mais que isso, funcionando como um contraponto do que vem a seguir: a escolha por caminhos não tão valorizados pela própria família, apesar das boas condições de vida afetiva no grupo familiar e no bairro:

Fui ficando mocinha e dos 12 para os 13 anos já não queria mais ir para a capoeira, nem festas de batizados, nem estudar. Passei a arrumar outras amizades e comecei a namorar um viciado em drogas. Por incrível que pareça, a família dele inteira se envolvia com coisa errada, até a mãe, que era uma alcoólatra. Minhas amizades foram se tornando constantes com pessoas bem mais velhas que eu. Larguei de vez os estudos e aos poucos fui me afastando de casa (Claudelaine da Silva, A Diferença da Vida, in Letras da Liberdade, 2000, p.25).

Tudo começou quando tinha 14 anos... foi quando descobri a maconha... no começo era somente diversão. Morava num bairro de classe média alta e fumava maconha apenas para me divertir, mas logo fiz amizade com pessoas que tinham grande influência na vida do crime. Aos 16 anos, comecei a usar cocaína, daí por diante, foi só perdição (Júlio Molina, Aguardando um bonde a qualquer momento, in Letras da Liberdade, 2000, p. 31).

$\mathrm{Na}$ escola onde ela estava estudando, encontrou crianças de vários tipos de vida. E com a solidão, com o vazio que ela sentia, ela procurou uma

\footnotetext{
${ }^{74} \mathrm{~A}$ assinatura do autor apenas a partir das iniciais indica que ele é um adolescente e, por isso, tem seu nome preservado.
} 
solução para o frio dessa solidão. Mas ela procurou o remédio errado, começou a se envolver com drogas. Elaine conheceu alguns coleguinhas que moravam na favela do Cruzeiro e essas crianças, desde pequenas, já conheciam a vida no crime (E. R., Aprendendo com a vida, in $\mathrm{O}$ direito do olhar, 2009, p.139).

As drogas aparecem nas narrativas como o ponto a partir do qual uma infância feliz se transforma numa adolescência conturbada e propícia ao crime. É a partir do envolvimento com "más amizades" e o início do uso de drogas, que depois se torna contínuo, que os personagens se afastam da família, marcando ali, muitas vezes, um rompimento; trata-se do momento de saída de casa, da sobrevivência amparada em pequenos furtos ao lado de outros adolescentes em situações semelhantes.

Estes excertos, em que os autores buscam construir uma lógica coerente para suas trajetórias dando sentido às escolhas tomadas e aos caminhos percorridos, se analisados tendo como base seu contexto de produção - o cárcere - nos permitem vislumbrar as tensões e os jogos de força atuantes na prática da escrita na prisão. Se a escrita de si, de maneira geral, é prática voltada para um interlocutor diferente do autor, nos textos produzidos a partir dos concursos prisionais, a presença deste "outro" é o que inaugura a própria cena da escrita: os autores escrevem incentivados por alguém de fora da prisão, e o texto escrito terá que passar pelo olhar de um avaliador que irá atestar a qualidade daquilo que foi produzido.

Este "olhar avaliador", no entanto, não se concretiza apenas na leitura realizada pelo jurado do concurso prisional, antes, está presente em outros sujeitos que exercem, no cárcere, o papel de inquirição, não apenas dos textos produzidos, mas das ações dos presos em geral. Presos e presas estão, a todo momento, sendo avaliados em suas atitudes, seja pelos próprios colegas - naquilo que Marques (2009) chama de "caminhada impecável" - seja pelos funcionários e pela instituição, por meio de agentes prisionais, psicólogos, diretores, médicos e afins. Apesar da pena de cada um deles ser promulgada por um juiz, são esses sujeitos que irão definir a maneira como ela será cumprida: se tiver bom comportamento, o preso pode receber algum tipo de benefício e cumprir o restante da pena numa instituição penal que conte com o regime aberto ou semi-aberto, por exemplo. Portanto, a saída do presídio depende de seu comportamento no interior da prisão e a avaliação sobre esse comportamento não é algo objetivo, antes, é o resultado de uma série de opiniões em que 
sujeitos diferentes atestam, a partir de critérios pouco claros, que o preso tem condições, ou não, de progredir de regime.

Neste contexto de avaliações contínuas, o espaço da escrita é apropriado por alguns como uma oportunidade para falar sobre si tendo como pano de fundo a presença desse "olhar avaliador". É bastante comum que haja, ao final dos textos, um agradecimento em que o autor fala da alegria de poder participar do certame, tendo a oportunidade de comentar o que foi trabalhado durante o texto. Essa postura de gratidão pode apontar para vários sentidos, entre os quais: a oportunidade de demonstrar, por meio do texto escrito, a transformação que a instituição espera deles e com isso facilitar o processo de avaliação sobre a sua conduta e o alcance de algum benefício; ou ainda a oportunidade de apresentar a sua versão dos fatos que o levaram à prisão, já que durante o processo jurídico eles pouco são ouvidos pelos profissionais do sistema de justiça; seja ainda para denunciar alguma irregularidade no presídio ou no seu processo penal.

A gratidão enunciada pelo preso no texto revela não apenas a presença desse "olhar avaliador" como aponta também para estratégias elaboradas pelos autores para alcançar esse “outro" em função de interesses específicos. Ao identificar a presença de um interlocutor, o sujeito elabora sentidos diversos para sua escrita, definindo o significado de sua ação e garantindo a ela uma significação específica dentro do jogo de poder sempre atuante no cárcere.

Nos excertos mencionados acima, é possível perceber um uso particular da escrita, que carrega uma autoavaliação tendo como base o olhar deste "outro": o preso e a presa narram as suas trajetórias no intuito de compreender (e dar a compreender ao interlocutor) o que os levou a uma vida no crime, de forma a identificar um culpado. A infância feliz, de um lado, resguarda a família, deixando claro que se eles estão na prisão, não seria porque receberam pouco na infância, ou porque a família não soube lhes dar limites. A culpa por suas trajetórias e ações estaria, portanto, neles mesmos. Foram suas escolhas - e não o contexto - que levou cada qual à prisão.

Ao descrevem seus percursos, os autores chegam, invariavelmente, a uma mesma conclusão: "o crime não compensa". A partir dela é possível compreender, num primeiro momento, o encadeamento da narrativa: quando pequenos, viviam de maneira simples mas felizes com a família; quando adolescentes, fizeram "más amizades" e conheceram as drogas; devido ao uso de drogas começaram a roubar para sustentar o vício e aí entraram no mundo 
do crime; uma vez no mundo do crime, conheceram a prisão, e ali, na prisão, vivendo momentos de muita abstinência, reveem a sua trajetória e chegam à conclusão que foi o crime que tirou de cada um deles o que mais amavam: a família e a liberdade.

Ao nos determos sobre essas narrativas, em que os presos ordenam e oferecem sentido para suas trajetórias, é possível perceber que, de acordo com elas, não seriam as contravenções cometidas o que os teriam levado à prisão, mas a origem da trajetória delituosa encontra-se, antes, nas drogas. A "perdição" de cada um não se inicia com as ilegalidades, mas com as "más companhias" e com o uso de drogas. Se de fato esta é a história de cada um, a conclusão deveria ser outra: mais perigoso que o crime é o que os levou até ele, como pode ser percebido nos excertos reproduzidos acima, em que três autores diferentes constroem suas narrativas de forma bastante similar. O desfecho narrativo não tem como lema a ideia de que o crime não compensa, mas antes, de que as drogas não compensam.

Ao identificar nas drogas ou nas más companhias a origem de suas trajetórias na criminalidade, os narradores estariam tirando o foco do que realmente parece importar para a instituição prisional, que é perceber no detento uma consciência de si e do crime cometido, sem o esforço de colocar em terceiros uma culpa que deveria ser somente dele. Se, como dissemos, a instituição prisional valoriza a escrita no cárcere como prática voltada à ressocialização, o texto produzido deve também estar ancorado nesse valor de regeneração para que seja reconhecido como adequado ou bom pela instituição. Dessa forma, a escrita prisional é utilizada pelos presos como meio para provarem sua recuperação, e uma das formas de atestarem inocência ou mudança é adequando-se aos valores institucionais de restauração do sujeito por meio da confissão da culpa, quando tomam para si a total a responsabilidade por seus atos. Uma leitura cuidadosa dos textos aponta para diversas "culpas" (más companhias; uso de drogas; pobreza; desestrutura familiar, ainda que os pais sejam preservados nas narrativas), indicando muitos sentidos para as trajetórias narradas; mas a conclusão a que se chega, porém, é sempre aquela esperada pela instituição, em que o preso assume sua responsabilidade e afirma que "o crime não compensa", o que revela uma tensão entre a maneira como a instituição valoriza e percebe o texto dos presos e as formas pelas quais estes se apropriam da escrita e a utilizam para alcançar seus objetivos dentro da instituição prisional: 
Hoje, nada mais quero com essa vida abjeta, da qual muito me envergonho. Foram estruturas sociais injustas que me conduziram a essa condição subumana da qual espero sair, ainda... Devo assumir e reconhecer que a culpa cabe apenas a mim e, por isso, pago com lágrimas de arrependimento e até mesmo com o próprio sangue essa saga a caminho sempre de um abismo mais e mais fundo. Que esta trágica experiência sirva para alertar que o crime não compensa (Luiz Campos, Minha Vida na Delinquência, in Letras da Liberdade, p. 64).

Juntamente com a confissão e o arrependimento, constrói-se uma promessa acerca do futuro, quando o preso afirma que fará tudo diferente no momento em que sair da prisão. Nesse sentido, o texto de Vanderlei Fischer é exemplar, já que arrola elementos presentes em quase todas as narrativas produzidas a partir dos concursos literários na prisão. Em Vida Bandida, Fischer narra a sua trajetória também retornando à infância, às amizades e à iniciação na vida do crime. No momento da escrita, quando se encontra preso, examina a sua situação e afirma não querer mais esse tipo de vida:

Meu futuro ainda é uma incógnita. Mas cheguei à conclusão de que o crime não compensa. Minha família acredita em minha capacidade e nunca me abandonou. Estou fazendo os exames para o semiaberto e tenho fé em sair em liberdade com mais um ano ou dois. Agora que meu lado criminoso já não existe mais, tenho em minha mente a firme ideia que não deixarei mais escapar: reconstruir minha vida!!! Jamais esquecerei do meu melhor amigo e irmão do coração, que sempre me abraçava após um assalto bem sucedido e dizia: 'Du Fischer, a vida da gente dá um livro!' (Vanderlei Fisher, Vida Bandida, in Letras da Liberdade, 2000, p. 46).

No momento em que finaliza seu texto, afirma que não deixará escapar a ideia de reconstruir sua vida. No entanto, ao longo do relato, o autor aponta para o enfrentamento de diversas dificuldades nos momentos em que saiu do presídio e buscou reconstruí-la por meio de um emprego legal:

Procuramos [emprego], procuramos, procuramos e não encontramos. Desesperados, mais uma vez partimos para o lado negro. Apareceu uma 'fita' [oportunidade] de $\mathrm{R} \$ 20.000,00$ pra gente pegar... Pôxa! Ia ser o começo da reviravolta em nossas vidas! Estávamos cansados de sofrer na cadeia, mas sem um começo, sem perspectivas naquele momento, não encontramos outra saída a não ser essa... (Vanderlei Fisher, Vida Bandida, in Letras da Liberdade, 2000, p.45). 
A procura por um emprego se torna uma constante ao longo da trajetória de Fisher, e aparece, portanto, como uma justificativa para a volta à criminalidade: "não encontramos outra saída a não ser essa". A promessa de reconstrução de uma nova vida que se encontra ancorada em um novo sujeito ("agora que meu lado criminoso não existe mais") é elaborada, no texto, pouco depois do relato das inúmeras tentativas de encontrar um emprego nos momentos em que experimentou a liberdade. O autor relata, então, que "naquele momento" eles e os companheiros não encontraram outra alternativa a não ser participar de novos atos de contravenção. Ao reconstruir seu percurso, o autor aponta para a impossibilidade da ressocialização do preso, já que a este é negado o acesso a um emprego, o que justificaria as "recaídas" no crime. Mas, no momento em que escreve seu texto, Fisher olha para o futuro e afirma que, agora, as coisas funcionarão de uma forma diferente. As recaídas do autor não parecem ser o resultado da existência de um sujeito criminoso; antes, estão ancoradas numa estrutura social que exclui o preso, mesmo quando este já pagou a sua pena. Se a sociedade que o espera fora da prisão é a mesma, o otimismo de Fisher quanto à sua nova vida não parece estar baseado em alguma promessa de emprego ou na esperança de uma nova vida, mas antes na elaboração de um discurso que é esperado pela instituição prisional, que acredita realmente numa possível ressocialização do preso.

Esta incongruência entre o desejo de Fisher e aquilo que ele sabe que o espera do lado de fora das grades é repleta de significados. Qual seria a conclusão esperada para o texto de um preso, tendo em vista o cenário institucional, em que o autor está sendo avaliado por diversos sujeitos, tanto aqueles que se relacionam com o concurso quanto aqueles que estão dentro da instituição? Seria prudente dizer, naquele momento, que o que o espera do lado de fora é a mesma realidade de quando ele entrou para o presídio? Ele poderia afirmar que a única alternativa que lhe resta é, como sempre, o crime? O desejo de "reconstruir sua vida" aponta não para uma falta de conhecimento de sua realidade (como afirma André du Rap, ele irá carregar sua "carteirinha de bandido" para sempre), ou para uma mentira contada (apesar de ter consciência de que o que o espera do lado de fora é o crime, como tantas vezes foi narrado por ele). Tal incongruência indica um uso "tático",75, o que significa dizer que Fischer usa a escrita como um produto capaz de lhe oferecer alguns benefícios, já que irá atestar,

\footnotetext{
75 Para Certeau (2013), as artes do fazer podem ser pensadas a partir de duas operações que se relacionam com a determinação de um lugar, sendo este lugar o espaço onde se realizam as operações (os fazeres) e também onde acontecem as disputas. As estratégias, para Certeau, são as operações efetivadas por aqueles que detêm o poder de determinar este lugar, mapeando-o; as táticas, por sua vez, são efetivadas por aqueles que não possuem esse poder de impor ou determinar um lugar, mas atuam sobre este a partir de ações que o manipulam ou alteram. Os autores presos não são capazes de determinar um lugar da escrita - o que é feito pela instituição prisional juntamente com os elaboradores do concurso -, mas, ao escreverem, se apropriam deste fazer e o utilizam de forma a transformar seu uso, por isso, fazem um uso tático da escrita.
} 
para quem interessa, a sua ressocialização, a partir da autoconfissão de recuperação e da reafirmação de que ele está apto a voltar a viver em sociedade.

Esse uso tático do texto, em que o autor compartilha, em certos momentos, o sentido de ressocialização e, em outros, o contrapõe, é possível ser percebido também em outros escritos, em que a experiência no crime é exaltada como uma vida de sucesso, para, no final, afirmar-se que "o crime não compensa". Valdelice Torres, por exemplo, é a autora de um texto intitulado Sonhos... Fama, em que ela narra a trajetória de uma "mulher loira". O texto, narrado em terceira pessoa, retrata a trajetória de uma menina que vivia com a sua família, mas que aos poucos foi se entediando daquela vida, passando a procurar por "aventuras". Foi quando a "mulher loira" passou a andar com pessoas envolvidas com a criminalidade e procurou, então, buscar o seu sonho, que era ser "famosa". Este sonho se torna realidade quando a "mulher loira" converte-se na pessoa mais procurada de São Paulo, tendo sua foto estampada nos jornais.

Presa muitas e muitas vezes, com vários processos, várias passagens, cada vez aprendia mais no mundo do crime. Ela sabia que os heróis de verdade são pessoas de fala mais mansa, por isso impunha seu respeito com humildade às pessoas. Muito procurada pela polícia, presa novamente, viuse diante das câmaras de TV. Nos anos 90, embora tenha se recusado, 'apareceu' numa reportagem do Globo Repórter, como 'A mais procurada de São Paulo'. Seus sonhos... fama (Valdelice Torres, Sonhos... Fama, in Letras da Liberdade, 2000, p.142).

A reiteração de algumas palavras, como "muitas e muitas vezes", "vários processos" e "várias passagens", aponta para uma valorização dessas ações. Apesar do destino trágico que a autora indica no final da narrativa - quando é presa e vive de forma solitária no cárcere sua trajetória é traçada como cheia de glamour, em que a "mulher loira" alcançou, por meio da criminalidade, o sucesso que desejou enquanto criança. "Inteligente e ligeira, sempre tem sua palavra final em qualquer evento ou situação. Agora, ela pertence a uma quadrilha de assaltantes de bancos. Só uma mulher, ela. Era a soberana, preferida por todos, para qualquer evento" (Valdelice Torres, Sonhos... Fama, in Letras da Liberdade, 2000, p.143). Apesar da trajetória de "sucesso", a conclusão do texto aponta, da mesma maneira que os demais, para a infelicidade trazida pela vida na criminalidade, por terminar, invariavelmente, na prisão: 
A mulher loira entende que errou para a sociedade. Entende que o seu conceito na vida do crime foi conquistado através de anos, e que não precisa mais de fama. Agora procura viver dentro da verdade. Mas, o que é a verdade? É viver 'com os pés no chão', desprovida de 'sonhos materiais', estar no Sistema e evitar cometer erros estúpidos. Nada mais triste do que uma pessoa que tenha vivido num mundo de mentiras. [...] A garota jovem, mulher loira, abusou muito na juventude e não concorda em culpar o mundo inteiro por isso, mas sabe que uma parcela de culpa deve a ele (Valdelice Torres, Sonhos... Fama, in Letras da Liberdade, 2000, p.143).

Estar no "Sistema" é agora a sua "verdade", a partir de um "entendimento" acerca do "erro perante a sociedade". A "verdade" é ter uma vida "desprovida" de "sonhos materiais", é, portanto, uma vida que hoje nega aquilo que ela viveu no passado. Mais uma vez é possível perceber aqui, assim como no texto de Fischer, uma incongruência entre o que texto diz, reafirmando as conquistas durante a vida no crime, e uma conclusão que nega todas essas conquistas, dizendo que o crime não compensa.

A partir da elaboração de narrativas em que se exalta a vida no crime, os autores valorizam suas trajetórias, responsáveis pela construção de uma identidade e de uma subjetividade próprias. As narrativas constroem, no entanto, um sentido esperado pela instituição a partir da escrita, que se liga à afirmação reiterada da ressocialização. Ao afirmarem que o crime não compensa (por razões diversas), os autores trazem para a narrativa o efeito esperado pelo editor do concurso e diretores dos presídios: a noção de que a escrita, ao possibilitar uma autoavaliação, permitiria ao preso identificar seus erros e caminhar na direção de uma nova adequação à vida em sociedade. O texto revela-se assim um espaço de disputas, em que sentidos diversos são oferecidos pelos sujeitos envolvidos. O preso, no entanto, por encontrar-se no lado mais fraco da disputa, apropria-se da escrita a partir de um uso tático, como dito antes: ao oferecer à escrita o significado esperado pela instituição, ele tem a possibilidade de atestar, por meio da narrativa, a expiação da culpa e da salvação, o que lhe garante possibilidades de avaliações positivas e eventualmente alcançar os benefícios de progressão de regime. Ao se apropriarem dos sentidos oferecidos pela instituição, os presos, no entanto, reelaboram-nos a partir de um olhar que valoriza, se não a trajetória criminal, pelo menos a sua trajetória no crime, momento em que se reconhecem como sujeitos de sucesso, em oposição ao indivíduo objetificado produzido pela prisão. 


\subsection{O TEXTO COMO DENÚNCIA: NARRANDO AS INJUSTIÇAS DO SISTEMA JUDICIÁRIO BRASILEIRO}

Um dos usos que alguns participantes dos concursos fazem da escrita é o de instrumento de denúncia. A circulação dos textos premiados, resultado da publicação do livro, marca a possibilidade de interlocução entre o preso que escreve e o seu possível leitor. Mas esse leitor já se mostra presente no momento da escrita, quando o autor se propõe a narrar fatos e acontecimentos que foram silenciados no momento do seu processo judicial; se o juiz ou o delegado se negaram a ouvi-lo, a escrita se apresenta como uma oportunidade de narrar, a outrem, a sua versão dos fatos.

Dentre os textos de concurso publicados, dois deles se mostram representativos desse uso para denunciar as injustiças do sistema judiciário. O conto "A tortura", de autoria de Carlos Alberto da Silva, possui tom autobiográfico. Carlos Alberto conta como foi preso pela Polícia Federal, tendo sido torturado e obrigado a confessar a morte de um delegado. Esse texto não difere da fala de alguns presos que relatam que foram obrigados a "assinar" diversos crimes, quando torturados pelos policiais. Mendes, por exemplo, narra algumas seções de tortura em que os policiais exigiram que ele confessasse uma lista de crimes, o que acabou por aumentar a sua condenação.

O que chama a atenção no texto de Silva não é a denúncia em si, mas o modo como ela foi por ele elaborada. $\mathrm{O}$ autor narra com detalhes desde o momento em que foi abordado pelos policiais à noite, por volta das 22:30h, na saída de seu estabelecimento comercial, na cidade de Diadema/SP, como em seguida foi levado para uma dependência da Polícia Federal. Se detém, ainda, sobre a maneira como os policiais passaram a acusá-lo, sobre como ele começou a compreender o motivo pelo qual havia sido preso: para confessar um crime que não havia cometido.

Silva utiliza-se da escrita como um instrumento político de denúncia, ao mesmo tempo em que realiza, aí também, sua defesa. Ao longo do texto Silva cita nomes, sublinhando cada um deles: 
Após o término da sessão [de tortura], os Delegados CADEN, GIUSSEPE, LUA e MELO levaram-me para uma outra sala. Ali já se encontrava um escrivão a minha espera, onde queriam que eu confessasse uma morte no qual eu não havia feito, e nem teria motivos para tal. Diante da recusa, me surraram até quase a morte, resolvendo então preparar um depoimento em que eu era somente um mero espectador, por nada poder falar, porém o escrivão não parava de escrever as frases ditadas pelo Delegado Giussepe (Carlos Alerto da Silva Gomes, $A$ Tortura, in Letras da Liberdade, 2000, p.119, destaque do autor).

Silva nomeia policiais que o indiciaram e torturaram, da mesma forma como, mais adiante, cita o nome do advogado que o defendeu:

Pensei que iria levar mais uma série de golpes, mas para a minha alegria era finalmente um amigo advogado, que graças a Deus conseguira me localizar. Seu nome faço questão de dizer, Dr. RICARDO RENÊ RIBEIRO. Aí sim me localizei no tempo e no espaço (Carlos Alerto da Silva Gomes, $A$ Tortura, in Letras da Liberdade, 2000, p.120).

Os nomes citados no texto localizam pessoas, indicando a maneira como cada uma participou da sua trajetória, ora prejudicando-o, ora ajudando-o. Enquanto as destaca, constrói um mapa mental, organizando pessoas e relações que elas estabelecem entre si e também com ele, o que o ajuda a compreender sua própria trajetória ao mesmo tempo que indica, para os leitores, quem são os personagens relevantes naquela história, sublinhando principalmente aqueles que considera responsáveis pela sua prisão.

De acordo com ele, o processo jurídico que o tomou como réu foi montado pela Polícia Federal, que precisava de um culpado pela morte de um delegado, e ele parece ter sido o escolhido para cumprir essa função. O texto, portanto, funciona como a sua defesa, momento em que Silva narra a sua versão da história, esperando ser ouvido por alguém que acredite e confie no que está dizendo, o que leva a colocar o leitor na posição de juiz. Ao longo do relato, o autor procura construir, textualmente, a veracidade de sua versão, dotando-lhe de persuasão. No início afirma: "Uma história verídica, ocorrida nas dependências da Polícia Federal de São Paulo" (Carlos Alerto da Silva Gomes, A Tortura, in Letras da Liberdade, 2000, p.116). Assim que Silva abre o texto indicando a maneira como o leitor deve lê-lo: não com uma ficção, mas como o que de fato aconteceu, não sendo fruto da sua imaginação ou capacidade criativa. Mais adiante, reitera que trata de fatos verídicos, e 
utiliza elementos que procuram construir um referencial exato, de forma a contribuir com a ideia de veracidade:

Esta é a história verídica de um pacato cidadão, hoje conhecido no presídio por Carlão, nascido na Cidade Maravilhosa, que acreditou ser a capital paulista o local para formar sua família e dar um futuro melhor para seus filhos. Porém, o destino cruel e traiçoeiro lhe reservava atrações pouco atrativas. Estamos na cidade de Diadema, SP, no dia 28 de julho de 1998, aproximadamente 22:30h. Eu e meus funcionários saíamos da pizzaria, de minha propriedade. Ao chegarmos na frente da minha residência, fomos violentamente abordados por vários homens fortemente armados (Carlos Alerto da Silva Gomes, $A$ Tortura, in Letras da Liberdade, 2000, p.117).

Ao montar um arcabouço referencial para sua narrativa, conferindo-lhe foros de veracidade, o autor procura convencer o leitor de sua inocência. Não sabemos, tendo como base o texto em questão, se ele foi ou não ouvido durante o julgamento, ou se apenas a versão oficial da Polícia Federal foi suficiente para condená-lo. De toda forma, no momento em que se encontra diante da oportunidade de escrever que o concurso coloca, ele a utiliza para contar a sua história de maneira a construir para si e para os outros sua inocência mesmo tendo sido condenado pelo sistema de justiça. A escrita, para Silva, é um modo de produzir textualmente a sua defesa, não frente a esse sistema que já o julgou, mas frente ao avaliador do concurso e ao leitor que entrará em contato com seu relato.

Outro texto emblemático no uso da escrita como forma de denúncia é Lembranças ao Vento, de autoria de Márcio Marcelo do Nascimento Sena. Ele diferencia-se dos demais, já que não está baseado na história do próprio autor, mas na trajetória de Jesus, seu companheiro de prisão. Não sabemos as razões que levaram Sena a escolher a história do companheiro (e não a sua), mas é possível compreender que o autor aproveitou a oportunidade da escrita para denunciar a injustiça sofrida pelo colega. Talvez, para Sena, a história de Jesus seja mais exemplar que a sua própria história, por isso merece ser narrada e ser lida.

Jesus, como ficamos sabendo ao final do texto, não sabia ler nem escrever, o que o impediria de escrever sua história. É Sena, então, frente a esse saber-poder da escrita no cárcere, que dá a conhecer a história do companheiro a um público mais amplo. O texto deste autor se diferencia bastante do anteriormente analisado, já que ele não procura 
construir um efeito de veracidade; ao contrário, mescla elementos claramente ficcionais a uma narrativa que parece bastante comum no sistema prisional brasileiro.

Sena narra a trajetória de Jesus como um homem que deixou o nordeste e se mudou para São Paulo em busca de melhores condições para sua família; chegando ao destino, ele encontrou inúmeras dificuldades mas acabou por se estabelecer, mesmo diante da pobreza e das dificuldades. Trabalhava como pedreiro e a mulher, Lazinha, como doméstica, os dois tiveram uma filha, Ana Carolina, que era a "grande alegria da vida" de Jesus. Um dia Lazinha deixa a filha com o pai para ir trabalhar, e ao voltar para casa, percebe que a menina está desacordada:

Um cheiro forte de fezes paira no ar. Lazinha pega a menina, nervosa, e vê que Jesus dorme. No colo, uma garrafa vazia. Nem estranhou a menina estar gelada, pensando que era falta de roupas. No canto da cabeceira da cama, a mamadeira já azeda contribuía para o mau cheiro. Lazinha faz um gesto para apanhá-la. Percebendo o sangue no lençol, abraça, assustada, a menina. Sente o bumbum e a coxa suja com sangue seco, a frieza do corpo... Grita, cai desmaiada. Os vizinhos acodem sem entender o que acontece. Ao ver a menina caída e Lazinha chorando desesperada, deduzem. Já viram muitas vezes a violência e conhecem suas marcas. Jesus é espancado até perder os sentidos, sem saber ao menos o que se passava até acordar no distrito policial (Márcio Sena, Lembranças ao Vento, in Letras de Liberdade, 2000, p. 74 e 75).

Ao acordar no distrito policial, Jesus já é uma celebridade posto que seu "crime" havia sido noticiado nos jornais e muitos repórteres lotavam a delegacia em busca de novas informações. A partir daí, o texto narra os vários abusos físicos e violações sofridos por Jesus no distrito policial, enquanto o Delegado afirma ao repórter que: "Nossos homens farão tudo para protegê-lo, mas, como estuprador, é odiado até pelos presos, só Deus sabe" (Márcio Sena, Lembranças ao Vento, in Letras de Liberdade, 2000, p.75). No momento em que Jesus começa a ser torturado pelos colegas de cela, que se sentem ofendidos pelo fato de um estuprador ter sido colocado no meio deles, o delegado ouve seus gritos e os ignora:

Dez horas sai a 'subidinha', café noturno. A água esquenta, Jesus observa. Alguém pergunta se ele está encarando, a água cai... Jesus grita, começa o castigo, um fio é esticado e ligado na tomada.

- Você vai ficar chocado com o que vai acontecer - diz um, com sorriso, tocando Jesus com o fio. Gritos são ouvidos. O distrito está em silêncio. 
Grito de estuprador não conta, pensa o delegado, fumando um charuto cubano, presente do repórter que o entrevistara (Márcio Sena, Lembranças ao Vento, in Letras de Liberdade, 2000, p.76).

Depois da passagem pela carceragem da delegacia, Jesus é transferido para o presídio e é lá que conhece Sena, na escola da prisão, onde o narrador é professor. É nesse momento, então, que os dois travam uma amizade e Sena passa a acompanhar o caso de Jesus, que em pouco tempo é libertado, mas volta a cada quinze dias para visitar o amigo, já que encontrou nele a única pessoa que não o julgou pelo que aconteceu: “-Professor, eu sempre senti muita vergonha por estar preso, acusado de machucar minha princesinha; e o senhor foi a primeira pessoa que acreditou em minha inocência" (Márcio Sena, Lembranças ao Vento, in Letras de Liberdade, 2000, p.77). O texto prossegue com Sena narrando o desfecho do julgamento de Jesus, indicando os motivos pelos quais ele recebeu a liberdade em tão pouco tempo de prisão:

\footnotetext{
Disse que o Juiz havia pedido a autópsia do corpo da filha, mas o IML estava em greve, por isso não foi possível fazê-la nos primeiros dias de sua prisão. A greve provocara um acúmulo de trabalho. Quando tudo se normalizou e ele conseguiu a primeira audiência, já havia se passado oito meses. $\mathrm{Na}$ autópsia constara que sua filha havia morrido de diarreia crônica e desidratação. Foi com os olhos marejados que completou: '- E... era virgem como Maria, a mãe de Jesus' (Márcio Sena, Lembranças ao Vento, in Letras de Liberdade, 2000, p.77-78).
}

Sena diz que por dois anos Jesus o visitou quinzenalmente, até que começou a espaçar as idas ao presídio, em função de doença e, ao procurar um médico, foi diagnosticado com HIV - "No dia de sua prisão, fora estuprado e contaminado no distrito policial..." (Márcio Sena, Lembranças ao Vento, in Letras de Liberdade, 2000, p.78). Pouco tempo depois, Sena recebe um telegrama de Lazinha, avisando-o do falecimento de Jesus. O texto termina com as palavras da esposa sobre a relação que Jesus estabeleceu com o autor: "Caro professor, sinto informá-lo: morreu ontem à tarde seu amigo Jesus. Suas últimas palavras foram em agradecimento por ensiná-lo a ler e que Deus o abençoe” (Márcio Sena, Lembranças ao Vento, in Letras de Liberdade, 2000, p.78).

A narrativa de Sena traz uma história exemplar: ao narrar o infortúnio de Jesus o autor conta as muitas injustiças que acontecem no sistema de justiça criminal e também na 
“justiça dos homens". Jesus foi julgado e condenado bem antes que o juiz pudesse avaliar o seu caso: foi julgado e condenado pelos vizinhos que o espancaram; julgado e condenado pelo delegado que o deixou à mercê da fúria dos colegas de cela; julgado e condenado por esses mesmos colegas de cela, até que, quando finalmente foi julgado por um juiz, foi liberado porque as provas do crime o inocentaram. A demora do sistema judiciário em julgálo o fez permanecer na cadeia mesmo sendo inocente. A falta de proteção que o Estado deveria oferecer aos cidadãos que estão cumprindo pena e também em relação àqueles que estão sendo processados fez com que Jesus fosse violentado diversas vezes desde a morte de sua filha até a sua liberação por meio da sentença do juiz.

Sena utiliza a história emblemática de Jesus para falar de todas as injustiças e dos muitos erros cometidos pelo sistema judiciário; trata-se de uma história que carrega consigo vários elementos que indicam a fragilidade do sistema prisional, sem, no entanto, dizê-lo de forma direta. É o leitor quem chega a essa conclusão a partir da leitura. Diferentemente do texto de Silva, Sena não dá nomes, não oferece datas nem precisa a ação dos personagens. A sua denúncia não se volta para a veracidade do caso de Jesus, esse personagem que, não sem propósito, recebe o mesmo nome do Cristo que foi crucificado na história bíblica sem ter cometido nenhum pecado. Jesus é, aqui, a personificação de diversos presos inocentes que foram parar no presídio e só depois tiveram a sua inocência atestada pelo juiz - como foi o caso de Rodrigues que, depois de um ano no Carandiru, recebeu a absolvição em seu processo. A história de Jesus, portanto, é a história do sistema judiciário, uma história emblemática que ilustra a maneira como erros e injustiças são cometidos.

Enquanto diversos presos aproveitam a oportunidade para falar de si, elaborando exercícios de autoconhecimentos e identificação, Sena se apropria da escrita para narrar o outro, e ao fazê-lo, toca no sistema prisional e judiciário mais amplo. Nesse sentido, o texto de Sena pode ser considerado o mais político de todos eles, já que não acusa um ou outro policial corrupto, nem mesmo volta para si mesmo para tentar atestar sua inocência, mas utiliza a história de Jesus - real ou fictícia, não importa - para revelar, por meio de sua narrativa, a maneira como inocentes são massacrados por um sistema cruel.

Se a escrita é percebida institucionalmente como um instrumento de ressocialização, como indicam os concursos, uma análise que coloca a sua ênfase sobre a prática da escrita no cárcere revela que ela é capaz de construir muito mais que uma nova adequação à sociedade, como espera a instituição, já que é utilizada pelos presos de formas diversas, carregando muitos significados. Os textos dos concursos analisados revelam um uso político da escrita 
no cárcere, permitindo ver como tal prática, que está na base de criações voltadas para a vida no cárcere e para o sujeito preso, se dá a partir de um jogo intrincado de adequação e resistência. Escrever no cárcere é construir um mundo repleto de "apesares": apesar das grades, apesar da pena, apesar da violência, apesar das injustiças, apesar da criminalidade, apesar das regras do crime... 


\section{CONSIDERAÇÕES FINAIS}

O ano, agora, é de 2018, tendo se passado mais de 25 anos desde o dia em que a tropa de choque invadiu a Casa de Detenção de São Paulo, numa operação que culminou na morte de 111 presos. Em 2016, o Tribunal de Justiça de São Paulo anulou os julgamentos que condenaram 74 policiais militares a penas que variavam entre 48 e 624 anos de prisão, alegando que a decisão dos júris de condenar os policiais foi contrária às provas do processo. No ano seguinte, no entanto, o Superior Tribunal de Justiça (STJ) determinou que o Tribunal de Justiça de São Paulo analisasse novamente os embargos de declaração apresentados pelo Ministério Público de São Paulo, o que, na prática, suspende a decisão do Tribunal de Justiça de anular o julgamento.

Durante estes 25 anos, a memória do Carandiru foi sendo elaborada a partir do Massacre, e junto a ela, foi sendo construído um imaginário e uma memória sobre o cárcere. Um dos efeitos do Massacre, para além da violência covarde e cruel que dizimou mais de uma centena de vidas, foi derrubar simbolicamente os muros do cárcere e trazê-lo para fora, para as vistas de uma parcela da sociedade que se recusava a olhar e perceber o que havia do lado de dentro das grades ${ }^{76}$. É nesse momento, em que a sociedade passa a se interessar pela prisão e sua dinâmica, que alguns livros produzidos por presos começam a ser publicados e a ganhar o interesse do público leitor. A publicação destes livros remete a uma nova circulação

\footnotetext{
76 Ainda que o Massacre do Carandiru tenha derrubado simbolicamente os muros que separavam a prisão da sociedade mais ampla, trazendo ao conhecimento desta eventos e experiências que antes se encontravam velados, é importante sinalizar a interesse pelo cárcere de grupos específicos antes mesmo do Massacre, como é o caso de certos setores da sociedade envolvidos na discussão e luta pela garantia dos direitos humanos, desde o período da ditadura, enquanto se discutia de forma quase exclusiva o direito dos presos políticos, mas também quando se entra em pauta, a partir da atuação de José Carlos Dias como Secretário da Justiça do Estado de São Paulo, entre 1983 a 1986, quando buscou implementar um programa de humanização do cárcere.
} 
entre o interior e o exterior do cárcere, indicando a curiosidade de quem está do lado de fora do cárcere de conhecê-lo a partir da experiência de quem o vivencia pelo lado de dentro.

É nesse contexto de expansão de um imaginário sobre o cárcere que alguns livros produzidos por presos - do Carandiru e também de outras prisões - ganham o público a partir do ano de 2000, o que mais uma vez faz o cárcere extrapolar suas grades, permitindo um entendimento outro sobre a prisão. Tais livros, ao lançarem luz sobre o processo e a prática da escrita no cárcere, apontam para questões específicas tanto sobre a vida prisional quanto sobre a prática da escrita. Escrever no ou a partir do cárcere é, antes de mais nada, uma ação política. Escrever para não esquecer, escrever para lembrar; escrever para rememorar os mortos, escrever para fazer o luto; escrever para tornar sujeito, escrever para tornar humano; escrever para descrever a prisão, escrever para denunciar a prisão.

Apesar de reconhecermos uma variedade de livros produzidos no cárcere ou a partir dele nas últimas décadas, seis volumes foram elencados exatamente por chamarem atenção para questões específicas da produção literária na prisão. Sobrevivente André Du Rap e Pavilhão 9, de André Du Rap e Bruno Zeni, o primeiro, de Hosmany Ramos, o segundo, permitiram um entendimento sobre os processos de construção da memória a partir do Massacre, mas, mais que isso, apontaram para outras questões do cotidiano prisional que vieram à tona a partir daquele evento crítico. Rememorar o Massacre é, para estes autores, nomear os mortos, reconhecendo-lhes uma humanidade que lhes foi negada na hora de suas mortes. E essa rememoração se faz a partir do reconhecimento dos nomes e sobrenomes e também se faz com a reconstituição narrativa de suas mortes, indicando o número de tiros que levaram, tipos de ferimento, palavras e impropérios proferidos pelos carrascos nos segundos finais de suas vidas. Mas relembrar o Massacre é também narrar a prisão: descrevendo as relações que se constroem ali dentro; indicando regras de convívio e estratégias de sobrevivência frente à instituição prisional; indicando maneiras possíveis de lidar com a violência, por um lado, e com a solidão e a saudade, de outro. As narrativas sobre o Massacre inauguram, assim, uma narrativa sobre o cárcere, fazendo-o circular a partir de seus escritos.

Se André du Rap e Hosmany Ramos fazem o cárcere circular a partir da marca do Massacre, a leitura de Memórias de um sobrevivente e Vidas do Carandiru, de Luiz Alberto Mendes e de Humberto Rodrigues, respectivamente, indica o desejo de reconstruir um imaginário sobre o sujeito preso a partir de um enquadramento que o reconheça como humano. Se a prisão constrói o "bandido", esse que é identificado pelos seus "erros" diante da justiça, a escrita destes autores busca construir um sujeito humano que deve ser reconhecido e tratado 
como tal, ainda que tenha "errado", a escrita funcionando como um produtor de diferenças no cárcere, já que agencia, para aqueles que escrevem, o estatuto de "humano", enquanto aqueles que não escrevem estariam excluídos dessa categoria.

Esse esforço de diferenciação por meio da escrita não parte apenas dos presos que escrevem, mas pode ser percebido a partir de um olhar institucional, que valoriza a prática da escrita como uma atividade ressocializadora. Os volumes Letras de Liberdade e O Direito do Olhar, ambos resultados de concursos artísticos realizados em prisões paulistas, elucidam a forma como a instituição prisional confere sentidos específicos para a escrita no cárcere, valorizando-a como uma tarefa redentora, a partir da qual o preso seria capaz de refletir sobre a própria conduta e experiência, sendo transformado com tal reflexão. A escrita, portanto, denotaria a própria ressocialização: apenas presos transformados, nos indica essa visão, seriam capazes de escrever. Os detentos, por sua vez, se apropriam da escrita de formas diversas, ampliando seus sentidos e também seus usos. Se, por um lado, eles parecem se apropriar desse sentido de ressocialização que a instituição prisional concede à prática da escrita, por outro, os presos torcem esse entendimento, fazendo um uso tático da escrita, quando elaboram concomitantemente dois valores opostos a partir da prática da escrita: ainda que valorizem a "transformação" alcançada, a escrita é utilizada, também, para elaborar narrativas em que trajetórias criminais são exaltadas.

O cárcere é trespassado e constituído a partir de relações e tensões que o determinam, em um constante jogo de forças em que se fazem presentes diversos sujeitos e atores. Ainda que fechada em seus muros, há na prisão uma infinidade de relações entre seu interior e exterior que se constroem cotidianamente. A prática da escrita no cárcere nos permite conhecer algumas dessas relações, exatamente por deslindar as negociações simbólicas que se realizam em torno do entendimento acerca do preso e de sua humanidade, nas quais a sociedade externa ao cárcere se faz presente. Ler um texto do cárcere é, portanto, ler um mundo. 


\section{REFERÊNCIAS ${ }^{77}$}

\section{LIVROS PESQUISADOS}

AUTORES DIVERSOS. Letras de Liberdade. Madras Editora, São Paulo, 2000.IDDD. O Direito do Olhar: publicar para replicar . Instituto de Defesa do Direito de Defesa, São Paulo, 2009.

MENDES, L. A. Memórias de um sobrevivente. Companhia das Letras, São Paulo, 2009.

RAMOS, H. Pavilhão 9. Paixão e Morte no Carandiru. Geração Editorial, São Paulo, 2001.

RAP, A. D. Sobrevivente André du Rap (do Massacre do Carandiru).Coordenação

Editorial: Bruno Zeni. Labortexto Editorial, São Paulo, 2002.

RODRIGUES, H. Vidas no Carandiru. Histórias reais. Geração Editorial, São Paulo, 2002.

\section{LIVROS DO CÁRCERE}

BETTO, F. Cartas da Prisão. Círculo do Livro, São Paulo, Sem Data.

\footnotetext{
${ }^{77}$ De acordo com a Associação Brasileira de Normas Técnicas. NBR6023.
} 
BRASIL. Ministério da Justiça. Depen - Departamento Penitenciário Nacional. Escrevendo a liberdade: concurso de redação. Brasil. Ministério da Justiça. DEPEN - Departamento Penitenciário Nacional e Alfabetização Solidária, São Paulo, 2008.

CASTELANI, R. Carandiru. Um depoimento póstumo. Editora Lachâtre, São Paulo, 2007.

DOSTOIÉVSKI, F. Recordação da Casa dos Mortos. Martin Claret, São Paulo, 2006.

MENDES, L. A. Tesão e Prazer: memórias eróticas de um prisioneiro. Geração Editorial, São Paulo, 2004..

Às cegas. Companhia das Letras, São Paulo, 2005

, Cela Forte. Editora Global, São Paulo, 2012.

, Confissões de um homem livre. Companhia das Letras, São Paulo, 2015.

OBALUAÊ, N. Beco sem saída: eu vivi no Carandiru. Editora Rosa dos Tempos: Record, Rio de Janeiro, 1999.

PIETÁ, E. e PEREIRA, J. Pavilhão 9. O Massacre do Carandiru. Scritta Editorial, São Paulo, 1993.

PRADO, A. C. Cela forte mulher. Labortexto, São Paulo, 2003.

PRADO, J. Diário de um Detento. Labortexto Editorial, São Paulo, 2001.

RAMOS, G. Memórias do Cárcere. Martins Editora, São Paulo, 1965.

TEIXEIRA, H. A. Ventaneira: uma história sem fim. Editora UERJ, Rio de Janeiro, 1996.

VARELLA, D. Carcereiros. Companhia das Letras, São Paulo, 2012. Estação Carandiru. Companhia das Letras, São Paulo, 1999.

WILDE, O. De Profundis. Balada do Cárcere de Reading. Martin Claret, São Paulo, 2003. 


\section{CATÁlogos}

MUSEU DA CASA BRASILEIRA. Sobrevivências/Uma exposição sobre vivências: Carandiru. Catálogo. São Paulo, 2014.

\section{EXPOSIÇÕES}

PAPE, Lygia. Carandiru. Centro Municipal de Arte Hélio Oiticica, Rio de Janeiro, 2001.

RAMOS, Nuno. 111. Casa de Cultura Mário Quintana, Porto Alegre, RS, 1992.

24 Horas 111. 30ª Bienal de Arte de São Paulo, São Paulo, SP, 2012.

\section{FILMES}

CARANDIRU. Héctor Babenco. Brasil: Columbia Pictures do Brasil. 2003.

CARANDIRU OUTRAS HISTÓRIAS. Héctor Babenco. Brasil: Rede Globo. 2005.

CARCEREIROS. Fernando Bonassi. Brasil: Rede Globo. 2018.

PRISIONEIRO DA GRADE DE FERRO. Paulo Sacramento. Brasil. 2004.

SOBREVIVENTES, A HISTÓRIA DEPOIS DO CARANDIRU. PUC Campinas. 2014.

\section{JORNAIS E REVISTAS}

ESTADÃO, 4/10/2002. Fim da Detenção valoriza imóveis na região do Carandiru. http://brasil.estadao.com.br/noticias/geral,fim-da-detencao-valoriza-imoveis-na-regiao-docarandiru,20021004p20219. Acesso em 17/2/2017. 
FOLHA DE SÃO PAULO. Panorâmica, Cinema. "Carandiru” é líder de público e renda no país, 6 de junho de 2003,

http://www1.folha.uol.com.br/fsp/ilustrad/fq0606200339.htm. Acesso em 14/2/2017.

MARTI, S. Com público de 1 milhão, acaba ato de Nuno Ramos por mortos do Carandiru. Folha de S.Paulo, São Paulo, 2 de nov. de 2016, Ilustrada.

http://www1.folha.uol.com.br/ilustrada/2016/11/1828761-com-publico-de-1-milhaoacaba-ato-de-nuno-ramos-por-mortos-do-carandiru.shtml. Acesso em 13 de fevereiro de 2017.

Carandiru deixa 56 vítimas no AM";

Cotidiano, 2/1/2017, "Maior matança em presídios desde o http://www1.folha.uol.com.br/cotidiano/2017/01/1846359-maior-matanca-em-presidiosdesde-o-carandiru-deixa-56-vitimas-no-am.shtml. Acesso em 11/5/2018.

Cotidiano, 6/1/2017, Confronto mata 31 presos em RR;

essa é a segunda maior matança após o Carandiru.

http://www1.folha.uol.com.br/cotidiano/2017/01/1847511-33-presos-sao-mortos-em-

penitenciaria-de-roraima-diz-secretaria.shtml . Acesso em 11/5/2018.

DUNDER, K. Parque da Juventude convive com a memória do Carandiru. Veja São Paulo, Cidade, 17 de dez. 2010, São Paulo. http://vejasp.abril.com.br/cidades/santana-parque-dajuventude/. Acesso em 21/2/2017.

Revista Fórum, Luiz Alberto Mendes: "Escrevo livros, mas não sou visto como escritor", https://www.revistaforum.com.br/semanal/luiz-alberto-mendes-escrevo-livrosmas-nao-sou-visto-como-escritor/. Acesso em 7/4/2018.

\section{RELATÓRIOS}

DEPARTAMENTO PENITENCIÁRIO NACIONAL. Levantamento Nacional de Informações Penitenciárias INFOPEN - dezembro 2014. Brasília, Ministério da Justiça: 2014. 80 p.

\section{SITES}


www.companhiadasletras.com.br

www.g1.globo.com

$\underline{w w w . g e r a c a o e d i t o r i a l . c o m . b r}$

$\underline{\text { www.livreopiniao.com }}$

www.mcb.org.br

$\underline{\text { www.memoriamassacrecarandiru.org.br }}$

www.nunoramos.com.br

www.revistatrip.uol.com.br

www.saopaulo.sp.gov.br

$\underline{\text { www.sap.sp.gov.br }}$

\section{REFERÊNCIAS BIBLIOGRÁFICAS}

ADORNO, S. Sistema prisional brasileiro: problemas e desafios. Revista USP, n.9, p. 65 a 78, 1991.

ANDRADE, B. S. A. B. Entre as leis da Ciência, do Estado e de Deus: O surgimento dos presídios femininos no Brasil. 2011. 317 f. Dissertação (Mestrado em Antropologia Social) - Faculdade de Filosofia, Letras e Ciências Humanas, Universidade de São Paulo, São Paulo, 2011.

BARBOSA, A. R. Prender e dar fuga: biopolítica, tráfico de drogas e sistema penitenciário no Rio de Janeiro. Tese (Doutorado em Antropologia Social) - Museu Nacional, Universidade Federal do Rio de Janeiro, Rio de Janeiro, 2005. 
BICCA, A. Os eleitos do cárcere: etnografia sobre violência e religião no sistema prisional gaúcho. 2005. 197 f. Dissertação (Mestrado em Antropologia Social) - Instituto de Filosofia e Ciências Humanas, Universidade Federal do Rio Grande do Sul, Porto Alegre, 2005.

BIONDI, K. Junto e Misturado: Imanência e Transcendência no PCC. 2009. 196 f. Dissertação (Mestrado em Antropologia Social) - Centro de Educação e Ciências Humanas, Universidade Federal de São Carlos, São Carlos, 2009.

BUCKERIDGE, F. C. Por entre grades: um estudo sobre o cotidiano de uma prisão feminina. 2011. 112 f. Dissertação (Mestrado em Psicologia) - Instituto de Psicologia, Universidade de São Paulo, São Paulo, 2011.

BUMACHAR, B. L. Nem dentro, nem fora: a experiência prisional de estrangeiras em São Paulo. 2016. 380 f. Tese (Doutorado em Antropologia Social) - Instituto de Filosofia e Ciências Humanas, Universidade Estadual de Campinas, 2016.

BUTLER, J. Quadros de guerra. Quando a vida é passível de luto? Civilização Brasileira, Rio de Janeiro, 2016.

Relatar a si mesmo. Crítica da violência ética. Autêntica, Belo Horizonte, 2017.

CÂMARA, H. F. Além dos muros e das grades (discursos prisionais). EDUC, São Paulo, 2001.

CARRUTHERS, M. A técnica do pensamento. Meditação, retórica e a construção de imagens (400-1200). Editora UNICAMP, 2011.

CERTEAU, M. A invenção do cotidiano: 1. Artes de fazer. Vozes, Petrópolis, 2013.

CHARTIER, R. Inscrever e Apagar. Cultura escrita e literatura. Editora Unesp, São Paulo, 2007.

DAS, V. Fronteiras, violência e o trabalho do tempo: alguns temas wittgensteinianos. RBCS, vol. 14, n. 40, julho de 1999, p. 31 a 42.

(org). Remaking a world. Violence, social suffering, and recovery. University of California Press, Berkeley and Los Angeles, 2001. 
Life and words. Violence and the descent into the ordinary. University of California Press, Berkeley and Los Angeles, 2007.

O ato de testemunhar: violência, gênero e subjetividade. Cadernos Pagu (37), julho-dezembro de 2011, p. 9 a 41.

DIAS, C. C. N. São Paulo: a situação do Sistema Prisional em São Paulo. Relatório Nacional sobre os Direitos Humanos no Brasil. Núcleo de Estudos da Violência, USP, São Paulo, 2012, p.158164.

FASSIN, D. e RECHTMAN, R. The empire of trauma. An Inquiry into the Condition of Victimhood. Princeton University Press, New Jersey, 2009.

FÓRUM BRASILEIRO DE SEGURANÇA PÚBLICA e MINISTÉRIO DA JUSTIÇA. Juventude e Prevenção da Violência. Fórum Brasileiro de Segurança Pública, São Paulo, 2009.

FOUCAUlT, M. Vigiar e Punir. Nascimento da prisão. Vozes, Petrópolis, 1987.

O que é um autor. Vega Editora, Portugal, 1992.

A ordem do discurso. Aula inaugural do Collège de France, Pronunciada em 2 de dezembro de 1970. Edições Loyola, São Paulo, 1999.

GARLAND, D. (org.). Mass imprisionament: social causes and consequences. London: SAGE, 2011.

GODOI, R. Ao redor e através da prisão: cartografias do dispositivo carcerário contemporâneo. 2010. 203 f. Dissertação (Mestrado em Sociologia) - Faculdade de Filosofia, Letras e Ciências Humanas, Universidade de São Paulo, São Paulo, 2010.

Fluxos em cadeia: as prisões em São Paulo na virada dos tempos. 2015. 246

f. Tese (Doutorado em Sociologia) - Faculdade de Filosofia, Letras e Ciências Humanas, Universidade de São Paulo, São Paulo, 2015.

GOFFMAN, E. Manicômios, conventos e prisões. Perspectiva, São Paulo, 2005.

Estigma: notas sobre a manipulação da identidade deteriorada. LTC, Rio de Janeiro, 2013. 
GOODY, J. A domesticação da mente selvagem. Vozes, Petrópolis, 2012.

ILANUD, A lei de crimes hediondos como instrumento de política criminal. Revista Ultima Ratio, Ano 1 - n. 0, Lumen Juris Editora, São Paulo, 2006, p.3 a 72.

LAGO, N. B. Mulheres na prisão: entre famílias, batalhas e a vida normal. 2014. 108 f. Dissertação (Mestrado em Antropologia Social) - Faculdade de Filosofia, Letras e Ciências Humanas, Universidade de São Paulo, São Paulo, 2014.

LE BRETON, D. El rostro y lo sagrado: algunos puntos de análisis. Universitas Humanística, Bogotá, n. 68, jul.-dic. 2009, p. 139-153.

LEJEUNE, P. O pacto autobiográfico. De Rousseau à internet. Editora UFMG, Belo Horizonte, 2008.

MACHADO, M. (Org). Carandiru não é coisa do passado: um balanço sobre os processos, as instituições e as narrativas 23 anos após o Massacre. São Paulo, FGV Direito SP, 2015.

MACHADO, M. R.; MACHADO, M. R. A.; FERREIRA, L. M. A. Massacre do Carandiru: vinte anos sem responsabilização. Novos Estudos, n. 94, nov. 2012, p.4 a 29.

MARQUES, A. Crime, proceder, convívio-seguro: um experimento antropológico a partir de relações entre ladrões. 2009. 120 f. Dissertação (Mestrado em Antropologia Social) Faculdade de Filosofia, Letras e Ciências Humanas, Universidade de São Paulo, São Paulo, 2009.

OLIVEIRA, E. P. T. Mulheres em conflito com a lei: representações sociais, identidade de gênero e letramento. 2008. 145 f. Dissertação (Mestrado em Letras) - Centro de Ciências Humanas, Letras e Artes, Universidade Estadual de Maringá, Maringá, 2008.

PADOVANI, N. C. "Perpétuas espirais": Falas do poder e do prazer sexual em 30 anos (1977 - 2009) na história da Penitenciária Feminina da Capital. 2010. 175 f. Dissertação (Mestrado em Sociologia) - Instituto de Filosofia e Ciências Humanas, Universidade Estadual de Campinas, Campinas, 2010.

Sobre casos e casamentos: afetos e "amores" através de penitenciárias femininas em São Paulo e Barcelona. 2015. 366 f. Tese (Doutorado em Antropologia Social) 
- Instituto de Filosofia e Ciências Humanas, Universidade Estadual de Campinas, Campinas, 2015.

PALMEIRA, M. R. S. S. Cada história uma sentença: narrativas contemporâneas do cárcere brasileiros. 2009. 180 f. Tese (Doutorado em Letras) - Faculdade de Filosofia, Letras e Ciências Humanas, Universidade de São Paulo, São Paulo, 2009.

PEIXOTO, F. A. A viagem como vocação. Antropologia e literatura na obra de Michel Leiris. In: LEIRIS, M. A África fantasma. Cosac Naify, São Paulo, 2007, Apresentação, p. 19 a 33.

PONCIANO, J. C. Cartas da prisão: narrativa e alteridade. 2007. 160 f. Dissertação (Mestrado em Antropologia Social) - Setor de Ciências Humanas, Letras e Artes, Universidade Federal do Paraná, Curitiba, 2007.

REED, A. Documents Unfolding. In: RILES, A. (org), Documents: artifacts of modern knowledge, University of Michigan, 2006, p. 158 a 177.

SABAINI, R. T. Uma cidade entre presídios: ser agente penitenciário em Itirapina-SP. 2012. 160 f. Dissertação (Mestrado em Antropologia Social) - Faculdade de Filosofia, Letras e Ciências Humanas, Universidade de São Paulo, São Paulo 2012.

SALLA, F. As prisões em São Paulo: 1822-1940. São Paulo: Annablume, 1999.

SALES, K. L. As letras por entre as grades: consideração sobre a formação do leitor a partir de Memórias de um sobrevivente. Leitura: teoria e prática, n.53, ano XXVII, nov.2009, p. 46 a 52.

SCAPINI, C. Z. A construção do sujeito na autobiografia. E-scrita, Revista do Curso de Letras da UNIABEU, Nilópolis, v.4, n.1, jan/abr, 2013, p. 14 a 29.

SELIGMANN-SILVA, M. Narrar o trauma - A questão dos testemunhos de catástrofes históricas. Psicologia Clínica, Rio de Janeiro, vol.20, n.1, p.65ª 82, 2008.

SEVERI, C. Cosmologia, crise e paradoxo: da imagem de homens e mulheres brancos na tradição xamânica Kuna. Mana, 6 (1), 2000, p. 121 a 155. 
SILVESTRE, G. Dias de visita: uma sociologia da punição e das prisões em Itirapina. 2011. 192 f. Dissertação (Mestrado em Sociologia) - Centro de Educação e Ciências Humanas, Universidade Federal de São Carlos, São Carlos, 2011.

SYKES, G. Society of captives: a study of a maximum security prison. Princeton: Princeton University Press, 1971.

TAETS, A. R. F. Abrindo e fechando celas: narrativas, experiências e identidades de agentes de segurança penitenciária femininas. 2012. 185 f. Dissertação (Mestrado em Antropologia Social) - Faculdade de Filosofia, Letras e Ciências Humanas, Universidade de São Paulo, São Paulo, 2012.

TAUFER, A. L. Narrativas enjauladas: literariedade, testemunho e vivência em Memórias de um sobrevivente e Estação Carandiru. 2011. 207 f. Tese (Doutorado em Letras) Instituto de Letras, Universidade Federal do Rio Grande do Sul, Porto Alegre, 2011.

THOMAS, L. V. El cadáver. De la biología a la Antropología. Fondo de Cultura Económica, Cidade do México, 1989.

WACQUANT, L. As prisões da miséria. Rio de Janeiro: Jorge Zahar, 2001. 